\title{
Counter Terrorist Trends and Analysis
}

A JOURNAL OF THE INTERNATIONAL CENTRE FOR POLITICAL VIOLENCE AND TERRORISM RESEARCH

\section{Annual Threat Assessment}

GLOBAL THREAT FORECAST

By Professor Rohan Gunaratna

\section{SOUTHEAST ASIA}

Indonesia, Malaysia, Myanmar, Philippines, Thailand and Singapore

\section{SOUTH ASIA}

Afghanistan, Bangladesh, India, Pakistan and Sri Lanka

\section{CENTRAL AND EAST ASIA}

Kazakhstan, Kyrgyzstan, Tajjkistan, Turkmenistan, Uzbekistan and China

\section{MIDDLE EAST}

Iraq, Israel-Palestine, Lebanon, Saudi Arabia, Syria, Yemen and Qatar

\section{AFRICA}

Egypt, Libya, Nigeria and Somalia

\section{SOUTH AMERICA}

Colombia 


\title{
Executive Summary
}

\section{Annual Threat Assessment 2015}

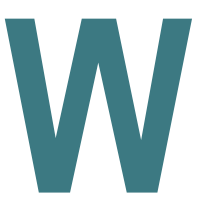

\begin{abstract}
e are happy to publish Volume 7, Issue 1 (January / February 2015) of the Counter Terrorist Trends and Analysis (CTTA) by the International Centre for Political Violence and Terrorism Research at the S. Rajaratnam School of International Studies, Nanyang Technological University, Singapore.
\end{abstract}

From a terrorism and counter-terrorism perspective, the year 2014 was particularly significant. This was due as much to the potential impact of drawdown of U.S. and International Security Assistance Forces (ISAF) from Afghanistan as to the declaration of the establishment of a so -called Islamic Caliphate by the Islamic State of Iraq and Greater Syria (ISIS). While the former has emboldened old and established groups like Al Qaeda Central, the Afghan Taliban, the Tehrik-eTaliban Pakistan and the Islamic Movement of Uzbekistan, among others, the claim of the establishment of the "so called Islamic State" by ISIS seem to have galvanised disparate elements within the Muslim world, drawing fighters in thousands to Iraq and Syria and spurring radicalisation and extremism in many countries on an unprecedented scale.

\section{Southeast Asia}

Even if there were no major attacks, the countries in Southeast Asia had to deal with the impact of ISIS. This was most evident in Indonesia and Malaysia with a number of citizens of respective countries found to be involved with ISIS - either joining the fight in Iraq or Syria or indulging in recruitment for the same or both. At the same time, regional groups, especially in Indonesia, continue to target the "near enemy" - the government establishment and its security apparatus and personnel. In the Philippines, even as Manila proceeds to finalise the negotiated settlement with the Moro Islamic Liberation Front (MILF), it had to deal with other armed groups in the country, such as the Moro National Liberation Front (MNLF), the Abu Sayyaf Group (ASG) and the Communists. Thailand continues to grapple with a fragile political process that has relegated Bangkok's dealing with the southern Thai militancy to the background. Finally, while Myanmar has been striding along on the routes to democratisation, it is still grappling with myriad ethnic armed groups, not the least of which has been the Rohingyas.

\section{South Asia}

Afghanistan has achieved a good measure of economic and social resuscitation since 2001. However, with rising levels of violence by the Taliban and no sign of a negotiated settlement between the warring parties, Afghanistan's future has become more uncertain. In Bangladesh, old groups continue to present threats to the country, while new outfits like Al Qaeda in the Indian Subcontinent (AQIS) are increasingly targeting the country. AQIS also has India in its sights, despite an overall decline in terrorist activity. Violent attacks continue unabated. The security threat in India is further heightened with the growing ISIS influence. In December 2014, Pakistan was shocked by a massive Taliban attack on a school in Peshawar as the government launched large counter-terrorism efforts in response to the threat. Meanwhile, Sri Lanka saw its first terrorist cell since 2009 this year, indicating that the surviving LTTE international network is continuing to rebuild its operational structures and capabilities. Post-war Sri Lanka is now also challenged by the presence of Islamist extremist groups and Sinhalese extremist groups on its soil.

\section{Central and East Asia}

Countries in Central Asia - Kazakhstan, Kyrgyzstan, Tajikistan, Turkmenistan, and Uzbekistan have two main concerns. The first is the drawdown of the U.S.-led international forces from Afghanistan, and the second is the increasing number of Central Asians travelling to Syria and Iraq to fight along with the ISIS and other jihadist groups. At the same time, the violence in Xinjiang and other parts of China and the presence of Uighur militants in the Middle East and in Southeast Asia have raised new concerns about the terrorist threat and Beijing's response to the same. 


\section{Middle East}

In 2014, events in the Middle East were completely dominated by the rise of ISIS which brought the involvement of the U.S. and the countries in Europe and most importantly some of the Muslim countries in the region to the forefront. Despite significant losses in terms of territory, personnel and financing, ISIS threat is still not out. At the same time, the Israeli-Palestinian conflict continues to be a major determinant of Middle East stability, as before. The resignation of the Yemeni President, the death of the Saudi King and the growing instability in Libya and Syria portend to significant challenges for the region's security in months ahead.

\section{Africa}

Egypt's challenges stemmed from frequent attacks on civilians and security forces by non-state armed groups galvanised by political instability. The outlook for Libya remains bleak, with diverse militias - once instrumental for the removal of Muammar Gadaffi - themselves becoming country's greatest security concern. While Nigeria reeled under Boko Haram threats, Somalia was hammered with attacks by al-Shabaab, despite the killing of its leader Ahmed Abdi Godane in September 2014.

\section{South America}

In 2014, Colombia experienced a continuation of attacks from the insurgent groups and from the country's right-wing armed criminal groups, Bandas Criminales. Peace talks also continued with the Fuerzas Armadas Revolucionarias de Colombia (FARC), despite continuing skepticism about its successful outcome.

\section{Looking Ahead}

From a counter-terrorism perspective, the response, either by concerned countries or collectively from the international community, remains deficient and often counterproductive as before. While many countries affected by the renewed violence lack capability, the support to these countries by the international community, especially by the U.S., has unfortunately, been ambivalent. This is further complicated by the debate about the nature of the threat, especially from ISIS and AI Qaeda that respective counties confront and the issue of commitment of resources by countries like the U.S. owing in a large part to domestic constraints.

Counter Terrorist Trends and Analysis is the journal of the International Centre for Political Violence and Terrorism Research (ICPVTR) of the S. Rajaratnam School of International Studies (RSIS) at the Nanyang Technological University (NTU), Singapore. The CTTA has a circulation of more than 13,500 subscribers.

\begin{tabular}{ll} 
Editor & Arabinda Acharya, PhD \\
\hline Associate Editor & Iromi Dharmawardhane \\
\hline Assistant Editors & Anton Chan, Stefanie Kam \\
\hline Design and Layout & Okkie Tanupradja
\end{tabular}

The views expressed in the articles are those of the authors and not of ICPVTR, RSIS, NTU or the organisations to which the authors are affiliated. Articles may not be reproduced without prior permission. Please contact the editors for more information at ctta@ntu.edu.sg. The editorial team also welcomes any feedback or comments. 


\section{Submissions and Subscriptions}

\section{Counter Terrorist Trends and Analysis}



aunched in 2009, Counter Terrorist Trends and Analysis (CTTA) is the journal of the International Centre for Political Violence and Terrorism Research (ICPVTR). Each issue of the journal carries articles with in-depth analysis of topical issues on terrorism and counter-terrorism, broadly structured around a common theme. CTTA brings perspectives from CT researchers and practitioners with a view to produce policy relevant analysis.

\section{CALL FOR CONTRIBUTIONS}

Counter Terrorist Trends and Analysis (CTTA) welcomes contributions from researchers and practitioners in political violence and terrorism, security and other related fields.

For more information please visit www.rsis.edu.sg/research/icpvtr/ctta, or to pitch an idea for a particular issue in 2015, please write to us at ctta@ntu.edu.sg.

For inclusion in the CTTA mailing list, please send your full name, organisation and designation with the subject 'CTTA Subscription' to ctta@ntu.edu.sg. 


\section{Global Threat Assessment New Threats on the Horizon?}

A series of developments - some new but mostly the legacy of more than a decade of terrorism and extremism and the fight against the same - warrants a re-write of the nature of the threat that the world faces today. These developments include the withdrawal of U.S.-led coalition forces from Iraq in 2011 and drawdown from Afghanistan in 2014, the Arab Spring fallout in the Middle East, and the flow of fighters in thousands from all over the world to Iraq and Syria, among others.

At the heart of these developments is the declaration of the establishment of a so-called Islamic Caliphate by the Islamic State of Iraq and Greater Syria (ISIS) (known as Ad Dawlah al Islamiyya fil Iraq wa ash Sham/Daesh in Arabic). More specifically, post-Arab Spring political chaos and instability in the Middle East have enabled fledging, mostly marginalised, groups to reorganise and pose threats to the security and stability of the world. While old actors such as Al Qaeda ('The Base') and its affiliates, including the Jabhat al Nusra (JN or 'Support Front for the People', also known as Al Nusra Front) are struggling to retain their prominence, new players, like ISIS, are competing for supremacy and legitimacy in the global jihadist arena. This has polarised radical and violent Muslim groups and individuals worldwide particularly in Asia, Africa, the Caucasus, and the Middle East. While some have pledged allegiance to ISIS, others remain loyal to AI Qaeda. At the same time, the sectarian divide within the Muslim world has hardened significantly, leading to increasing levels of violence in many countries.

\section{The Context}

Though Washington's October 2001 offensive in Afghanistan in response to the $9 / 11$ attacks did not elicit much opposition from the world community, the 
U.S. invasion of Iraq in March 2003 splintered the coalition, especially with regard to its allies in continental Europe, as well as diverted focus and resources away from the fight against Al Qaeda and the Taliban. It also galvanised the radical elements in the Muslim world. Groups like Al Qaeda and the Taliban exploited the general resentment to gain support and sympathies from fellow Muslims, which eventually metamorphosed into a worldwide opposition among a segment of the Muslims against the West in general, and the U.S. in particular, in the form of a global jihadist movement. With the invasion of Iraq, Al Qaeda and the Taliban leadership relocated to tribal Pakistan and Iran, reorganised, and began to carry out attacks in Afghanistan. At the same time, Iraq emerged as a new centre of international terrorism. The withdrawal of the U.S.-led coalition from Iraq in December 2011 and the marginalisation of Sunnis by the Nouri Al Maliki government created the conditions for the rise of the Islamic State of Iraq (ISI), the predecessor of ISIS. In many parts of the Middle East, the post-Arab Spring chaos provided opportunity for groups to re-emerge with renewed vigour and for new groups to appear. It also led to the relocation of Al Qaeda's focus to the Levant.

In October 2013, Al Qaeda under Ayman Al Zawahiri (now identified as Al Qaeda Central: AQC) disowned ISIS, led by the self-proclaimed Caliph, Abu Bakr al Baghdadi, for engaging in excessive violence and disobeying AQC's command to confine its operations in Iraq. ISIS' proclamation of an Islamic Caliphate on 29 June 2014 (first day of the month of Ramadan, 1435 in the Islamic calendar), has served to divert the loyalties of dispersed jihadist groups and individuals worldwide. Despite mass executions, graphic beheadings, slavery of women, and other atrocities, ISIS' battlefield successes have made its supporters turn a blind eye to its barbarism and brutality. Its wicked tactics also serve to instil a sense of awe and deference among its members and followers. ISIS has also taken the fight to the realm of the cyber space, with its Hollywood-style action-packed thriller media productions, eclipsing statements and videos of Al Qaeda leaders delivering long sermons, often viewed as boring and ramblings of the old guard. As opposed to traditional forums with limited audiences, ISIS has managed to engage a wide audience effectively with extensive use of social media-including Facebook and Twitter, serving to marginalise $A Q C$, its ideology, and influence.
"Despite mass

executions, graphic

beheadings, slavery of

women and other

atrocities, the

battlefield successes by

ISIS are making its

supporters turn a blind

eye to its barbarism and brutality."

\section{Evolution of ISIS}

ISIS evolved from Al Qaeda in Iraq (AQI), Tanzim Qaidat al Jihad fi Bilad al Rafidayn in Arabic or 'Al Qaeda Organisation in the Land of the Two Rivers,' led by Ahmed Fadil Nazal al Khalayleh, a.k.a. Abu Musab al Zarqawi. Abu Musab al Zarqawi created Jamaat al Tawhid wal Jihad ('Group for Monotheism and Holy War') in Iraq in 2003. In 2004, the group was renamed Al Qaeda in Iraq to fight the U.S. forces. The group also relentlessly targeted both the Shia and the Sunni, thus contributing to a civil war in Iraq. The killing of Abu Musab Al Zarqawi on 7 June 2006 in Hibhib in northern Iraq was followed by the emergence of the Islamic State of Iraq (ISI) from AQI. Consequently, ISI kept the U.S. engaged in bloody fights almost to the point of exhaustion. After the U.S. withdrawal from Iraq and during the post-Arab Spring civil conflict in Syria, ISI expanded its reach to Syria and renamed itself as the Islamic State of Iraq and Greater Syria (ISIS). Even though Al Qaeda Central shunned ISIS' adventurism, the group has succeeded in capturing the imaginations of a significant segment of Muslims worldwide. This has led to a virtual split among diverse jihadist groups in the Middle East, Asia, and Africa, with many groups supporting ISIS and distancing themselves from AQC, despite the latter's formative role in providing ideology, training, and financing to these entities. The virtual split among diverse jihadist groups materialised in the form of factionalisation of Al Qaeda in the Islamic 
Maghreb (AQIM) with Jund al Khilafa pledging allegiance to ISIS, and elements within AI Qaeda in the Arabian Peninsula (AQAP), with Ansar al Dawlah supporting ISIS. Similarly, TehrikeKalifefat supporting ISIS separated from the Tehrik-e-Taliban Pakistan (TTP). Groups like Boko Haram in Nigeria, Al Shabaab in Somalia, Sons of the Call for Tawhid and Jihad in Jordan, Jamaat Ansar Bayat al Maqdis in Egypt, and the Majlis Shura al Mujahideen in Gaza have pledged support to ISIS. In Southeast Asia, AI Jamaah al Islamiyah (JI) and Jamaat Asharut Tawhid (JAT) in Indonesia and Bangsamoro Islamic Freedom Fighters (BIFF) and Abu Sayyaf Group (ASG) in the Philippines, have split with some members of the groups supporting ISIS. Some groups have even acknowledged Abu Bakr al Baghdadi as the 'Caliph' of the Islamic State.

The ISIS Caliphate is also supported by a number of mosques in Western countries, especially in Australia, the U.K., and Canada. ISIS' defeat of the Iraqi Army, its seizure of large swathes of territory straddling Iraq and Syria, and the group's eventual declaration and establishment of a Caliphate are perceived by a segment of Sunni Muslims as serving a victory in the fight against Western dominance in the region as well as in the fight over Shia Iran. With its vast network of fighters and supporters worldwide, ISIS currently poses a threat of global proportions.

\section{Response}

The timely intervention by the U.S.-led coalition since September 2014 has prevented ISIS from expanding its territory and even relinquished some territory under its possession. However, groups like ISIS cannot be eliminated by air strikes alone. Likewise, even though it may be possible to degrade ISIS' strength through highly trained and specially equipped ground forces using real-time intelligence, the group could revive and continue waging the fight. This due to ISIS' appeal as the spearhead of the Caliphate and the group's ability to amass funding and other resources. With these funds and resources, ISIS could be emboldened to attract recruits from all over the world. To be successful, the fight against ISIS and the new generation of groups must also extend to counter-ideological movements and curbing sources of financial support, among other support sources. Governments need to partner with community organisations to facilitate the countering of

\section{"The fight against extremism should also be taken to the cyber space, where groups like ISIS, AQAP and $A Q C$ are exploiting with impunity."}

extremist ideologies and the promotion of moderation in Islamic discourse. Given how ISIS has deliberately distorted and misrepresented religion and exhibited itself as capable of carrying out large-scale brutalities through cruel massacres, it is also incumbent on mainstream Muslim leaders to remain vigilant to attempts by misguided leaders who use extremist propaganda to recruit members, particularly the youth. In addition, governments need to criminalise acts of advocating, supporting, and inciting religious hatred or participating in conflicts overseas. Through schools, youth organisations, and strategic communications platforms, governments must promote coexistence, moderation, and tolerance.

The fight against extremism should also be taken to the cyber space, where groups like ISIS, AQAP, and AQC are exploiting with impunity. The approach to tackle extremism on the cyber front involves monitoring and intervention with the aim to detect potentiality for radicalisation in individuals or individuals suspected of being radicalised. In democratic countries where curbs on freedom of speech are thought to infringe upon individual privacy as well as human rights concerns, monitoring and intervening on the cyber front could prove to a challenge. Hence, governments and citizens must weight the costs and consequences and to implement appropriate measures sensitive to the operational and contextual milieu.

\section{Looking Ahead}

Will ISIS replace AQC as the global leader of radical and violent movements? As a mostly selffinanced organisation with huge resources, large number of fighters and a growing global network, 
ISIS seems able to sustain the conflicts in Iraq and Syria and the region for a protracted period of time. The fight against ISIS is also likely to be prolonged, due to the existing schism and divisions among the countries in the region, besides diversion of counter-terrorism resources as the U.S. and other countries continue to fight groups like AQC and its associates concurrently.

Presently, the focus of the fight is to 'degrade and destroy' ISIS. Evidently, ISIS is most likely to retaliate, in one way or the other, targeting U.S. and its allies. At the same time, rising powers like China and India are increasingly forced to confront a growing threat from global terrorism. With the Taliban seeking to establish an Islamic State in Afghanistan and Pakistan, the threat in Xinjiang will increase, especially as segments of the Uighur community have been sharpening their skills by fighting in different conflict zones, including in Iraq and Syria.

The terrorist threat to India has heightened with the formation of the Al Qaeda in the Indian Subcontinent (AQIS), also known as AI Qaeda in South Asia. AQIS was created by AQC after the depletion of its Arab rank-and-file, but also as an attempt to replicate the success in Iraq - as the 'Iraqisation' of Al Qaeda reaped the group significant successes in Iraq. Pakistan and India are the main targets of AQIS. Working with factions of the Pakistani Taliban, AQIS also seeks to enlist dispossessed Rohingya Muslims to strike inside Myanmar. In this context, it is important that China continues and even strengthens its support to efforts taken by Pakistan and Afghanistan to dismantle the Taliban and Al Qaeda. Despite rivalry at the political level, it is imperative that China, India, and Pakistan cooperate with each other in counter-terrorism efforts, especially in the context of the U.S. and International Security Assistance Force (ISAF) drawdown in Afghanistan.

\section{Conclusion}

The scale of attacks and counter attacks by threat groups in Iraq and Syria targeting the regimes, Christians, and the Shia have raised the spectre of religious tension and violence worldwide. From the Middle East to Africa and Asia, communities that coexisted for centuries are now at loggerheads with each other. The acts amounting to ethnic and religious cleansing by ISIS are particularly precipitating anger, suspicion, and prejudice between Sunni and Shia Muslims, and between Muslims and non-Muslims. ISIS propaganda is politicising, radicalising, and militarising Sunni Muslim youth at an unprecedented scale, especially its message and actions that suggest Muslim supremacy, infecting a growing segment of the community. Like Al Qaeda ideology galvanised the radical segments of the Muslim community after the 9/11 attacks, ISIS has been able to create a global network of groups, homegrown cells, and individuals that are willing to kill and die. To win the fight against groups like AQC and its associates and ISIS and other likeminded groups the effort by governments should be multidimensional, involving diverse institutions, agencies and jurisdictions. To be effective, the international community must also pool its resources, share strategies, and collaborate in three areas: preventing radicalisation, criminalising advocacy, support, and participation in conflicts, and rehabilitating and reintegrating the combatants.

Professor Rohan Gunaratna is head of the International Centre for Political Violence and Terrorism Research (ICPVTR) at the S. Rajaratnam School of International Studies (RSIS), NTU. 


\section{Southeast Asia}

\section{Indonesia}

In 2014, the Indonesian government, especially the security establishment, remained the main target of terrorist attacks by Mujahidin Indonesia Timur (MIT) and its network, despite evidence of interest and in many cases involvement of the local jihadists in conflicts in Iraq and Syria. The Mujahidin Indonesia Barat (MIB) also carried out a number of criminal activities to support the funding of terrorism. Overall, the country's relatively weak legal regime continues to debilitate an otherwise robust counter-terrorism structure in the country from a long-term perspective.

Poso, the northeastern coast of Central Sulawesi, Indonesia, remained the epicentre of terrorism in Indonesia this year, followed by Bima in West Nusa Tenggara. The Mujahidin Indonesia Timur (Mujahidin of Eastern Indonesia), or MIT, led by Santoso, was allegedly behind a series of terrorist attacks targeting the police. From March to August this year, the alumni of the MIT's Poso training camp in Bima killed 3 police officers in a series of shootings. A police officer was also injured during an ambush attack carried out by the MIT on a police station in Poso. Two alleged members of the Mujahidin Indonesia Barat (Mujahidin of Western Indonesia) or the MIB also carried out a bank robbery in the Purworejo district of Central Java early this year. They were subsequently arrested. The group was led by Abu Roban, who was killed in a police raid in 2013. On 31 December 2014, 6 suspected terrorists from the MIB were gunned down in Ciputat, South Tanggerang, during a police raid. The six men killed in Ciputat were previously involved in a string of shootings on police in Greater Jakarta that claimed at least three lives and a bombing attack at the Ekayana Buddhist Temple in West Jakarta in August 2013.

In general, the Indonesian police remained key targets of terrorist attacks throughout 2014, reflecting the continuity in the shift from the "far enemy" to 
the "near enemy" - a trend that has manifested more intensively since the dismantling of the Aceh terrorist training camp in 2010 . At the same time, police's anti-terror unit - Detachment 88 - foiled several terrorist plots during raids conducted across the country and captured at least 54 terrorist suspects - a majority of whom were linked to the MIT.

\section{Tactics, Targets and Operational Structures}

Despite the successful operations by Detachment 88 to weaken Santoso's network of support in Java, West Nusa Tenggara, and Poso's neighbouring province, South Sulawesi, members of his network continued to carry out ambush, shooting, and stabbing attacks against Indonesian police. In addition, since the death of Noordin M. Top in 2010, there has been a decline in suicide attacks (Noordin had led a Jl faction responsible for scores of suicide bombings in Jakarta and Bali. From 2011 to 2013, there had been three suicide bombings which "only" killed the bomber. In 2014, there were no suicide bombing attacks. The decline in suicide attacks can be attributed to the death of Noordin Top as well as the generational gap in military capabilities among the Indonesian militants.

Comparatively speaking, the current generation of militants, including Santoso himself, lack the same standard of training and expertise as other Indonesian Islamist militants, particularly the veterans who had received training in Afghanistan (from the late 1980s to early 1990s) and in Mindanao (from the mid 1990s to early 2000s). These militants from the previous generation had received robust military trainings from these regions, and from smaller scale military trainings which were conducted in Mindanao and Poso up until 2007.

The militants' latest effort to establish a centralised military training in Indonesia had failed with the 2010 government crackdown on the camp in Aceh. The Aceh camp was set up by Dulmatin, a key figure involved in October 2002 Bali bombings, and supported by Abu Bakar Bashir leader of the Jamaah Ansharut Tauhid (JAT) group. The camp was subsequently named the Al Qaeda Serambi Mekkah, or Al Qaeda in Aceh. The terrorist leader Santoso, had offered a military training course that lasted around 2 months for each batch based on the concept of qital tamkin (creating a secure base for the establishment of an Islamic state), which was also propounded by Al Qaeda Serambi

\section{"In general, the Indonesian police remained key targets of terrorist attacks throughout 2014..."}

Mekkah. However the quality of the training fell flat due to lack of skilled trainers. A majority of the skilled militants were those who had received training in Afghanistan or Mindanao or who were involved in the Aceh training camp. However, these individuals had either been killed or captured.

Nevertheless, the Indonesian security apparatus continues to be targeted by MIT network for revenge - qisas (eye for eye) - mainly in response to the killing or arrests of the latter in counter-terrorism operations. The jihadists describe qisas as a justified retaliatory attack against the enemy, in particular, against those implicated in the killing or responsible for the death of Muslims. This argument was put forward by one of the main perpetrators of the 2002 Bali bombings, Imam Samudra, who had argued that targeting civilians was a matter of securing justice for the numbers of Muslim civilians killed by the U.S. The justifications for such attacks bear similarities to the causes for the attacks carried out by $\mathrm{JI}$ central on Christians up until 2007 in Poso, a site where bloody conflicts took place between Muslims and Christians during the late 1990s and early 2000.

Authorities have evidently been able to push MIT offensives on the ground, thereby serving to limit the group's ability to recruit members especially through radical sermons in mosques and schools. Yet, MIT has been attempting to compensate through an aggressive online propaganda strategy. MIT, which comprises of 20-30 core members who operate mainly in the remote mountainous area of Poso, continues to publish texts, audio, and videos in both Indonesian and Arabic extremist forums.

Arguably, this has helped MIT to enlarge its image and its reach. MIT was also successful in attracting Uighurs from China's restive Xinjiang province, a region which has seen a significant number of attacks allegedly carried out by Uighur minorities and an increased crack down on the 
Uighur by the Chinese authorities. The Uighurs had travelled via Cambodia, then to Thailand, and via Cambodia, then to Thailand, and subsequently by air to Kuala Lumpur and Indonesia, to meet with Santoso. Four of the Uighurs were arrested in September 2014 in Poso on charges of using fake Turkish passports. The incident highlighted the sensitivities of Indonesian groups to the issues in the wider Muslim community, whether in Iraq, Syria, China and elsewhere.

\section{Counter-terrorism Efforts}

In 2014, Detachment 88 successfully foiled several plots and arrested dozens, including those involved in the attacks. It also seized up to 93 motorcycles that were allegedly robbed by MIT members in Central Sulawesi.

In early August 2014, the Indonesian government banned the Islamic State of Iraq and Greater Syria (ISIS). Despite the ban, the existing legal regime in Indonesia does not confer upon authorities the power to arrest supporters of ISIS without proven evidence of their involvement in terrorist acts. Yet, according to official estimates, the number of Indonesians joining ISIS has soared from 56 in mid-year to over 110 by the end of 2014 .

A number of individuals who were openly displaying ISIS paraphernalia in their vehicles or house windows had been arrested but they were eventually released. Even Abu Fida and Afif Abdul Majid, who played influential roles in carrying out fundraising activities for ISIS and helped in facilitating the movement of Indonesian militants into Syria and Iraq, could not be charged for these activities. Police eventually charged them for past terrorist acts unrelated to ISIS. The lack of legal measures to prosecute individuals under suspicion of terrorism remains to be one of the most serious lacunae in Indonesia's overall counter-terrorism initiatives, despite best efforts by Detachment 88 at the tactical and operational levels.

\section{Looking Ahead}

In September 2014, ISIS leader Abu Bakar al Baghdadi called on his followers to kill American citizens as well as citizens of those countries that have joined in the U.S.-led coalition to attack ISIS in Syria and Iraq. At present, MIT is the only active terrorist group in Indonesia that has pledged allegiance (bayah) to Abu Bakar alBaghdadi and stands ready to pursue violence on ISIS' instructions.

\section{“...the existing legal regime in Indonesia does not confer upon authorities the power to arrest supporters of ISIS without proven evidence of their involvement in terrorist acts."}

The presence of foreign militants in Poso could strengthen the training skills and provide the logistical support for MIT to carry out more sophisticated attacks in the country. The partnership between foreign militants and local militants could also inspire other old or new jihadi groups and cells to conduct attacks against the "far enemy" in similar ways.

The arrests of dozens of suspected terrorists in 2014 indicate that Detachment 88 continues to remain pro-active and mostly successful in the crack down on terrorists in the country. At the same time, the move by the Indonesian government to ban the ISIS is a positive and a historic initiative - given that the Indonesian government has not yet banned Jemaah Islamiyah $(\mathrm{JI})$ as a terrorist group in view of a judicial acknowledgement of the group's terrorist propensities.

This is due largely to the weak legal regimes in the country and external conflicts including ongoing developments in Syria. These weaknesses are being exploited by the MIT as well as by other jihadi groups. An important shift is the ability of domestic groups to fully harness the online domain and make emotive appeals for recruitment and fundraising.

This remains a key challenge going forward. It is however unlikely for the new government under President Jokowi to pass laws requiring parliament approval to address the problems above. 
Despite efforts to strengthen the existing anti-terrorism legal regime, the lawmakers remain divided on a number of issues. It is in this context that the initiatives of the current Minister of Religious Affairs, Lukman Hakim Saifuddin and Saud Usman Nasution, the new head of Indonesia's Counter Terrorism Agency (BNPT), are noteworthy especially with regard to engaging the community in countering the appeal of ISIS particularly and the jihadist ideology broadly.

Ultimately, the role of the community in combating radical ideology is critical. Communities and the concerned agencies need to adopt a more cooperative approach in spreading narratives of peace and tolerance to ensure that their messages are heard above the terrorist and extremist messages of hate and violence.

V. Arianti is an Associate Research Fellow with the International Centre for Political Violence and Terrorism Research (ICPVTR) at the S. Rajaratnam School of International Studies (RSIS), NTU. 


\section{Southeast Asia}

Increase in interest in militant jihad in Malaysia, as well as the threat posed by returning Malaysians who have travelled to Iraq and Syria to fight, have been the most important developments for the country in 2014.

In 2014, Malaysia experienced a significant increase in terrorist activities, most of which were closely linked to the ongoing Syrian conflict, as well as to the extremist group Islamic State of Iraq and Greater Syria (ISIS) in the Middle East. In particular, there was a spike in the number of Malaysians travelling to join the conflicts overseas. Malaysian fighters with social media presence on Facebook and Twitter also garnered large followings and 'likes' from supporters back home - highlighting the potential general increase in enthusiasm for militant jihad. At the same time, the threat posed by Darul Islam (DI or State of Islam), a terrorist grouping at least 50 years old that originated in Indonesia and developed cells in Malaysia, also re-surfaced, along with the emergence of four new groups designated by authorities as terrorists in Malaysia. Concerns that extremist groups and individuals within Malaysia would be motivated by ISIS' propaganda to link up with terrorists in Southeast Asia have prompted Malaysian authorities to step up counterterrorism efforts, leading to the arrest of 40 individuals for terrorism-related offences this year. Authorities also thwarted a planned terrorist attack. Malaysia tabled a White Paper on Terrorism in December 2014, which is expected to set the stage for more robust counter-terrorism mechanisms for Malaysian agencies.

\section{Radicalisation in Malaysia}

In 2014, radicalised individuals within Malaysia seem to have derived inspiration from a combination of two sources - firstly, from humanitarian and socially motivated issues involving the ongoing violence in Syria and 
elsewhere in the Middle East, and secondly, from the Islamist religio-political belief that the declaration of the establishment of an 'Islamic State' and a Caliphate by ISIS group under Abu Bakr al Baghdadi appears to have fulfilled.

Malaysians fighting in Syria for humanitarian or social reasons have distanced themselves from ISIS, and the support for supposed humanitarian causes seems to be growing in the country. An example is Mohd. Lotfi Ariffin, a former PAS (Parti Islam Se Malaysia, or Pan-Islamic Party) member who died while fighting in Syria. Ariffin and numerous others like him in Malaysia have joined diverse Islamist groups fighting in Syria, such as Ajnad al-Sham and not necessarily ISIS. In their writings on social media they frequently make reference to more humanist ideals rather than Islamist ones. Ariffin, for example, had stressed on his Facebook postings that he was "in Syria not because of this or that faction. (He was) here because of jihad fi sabilillah (the fight in Allah's cause)." His older brother also stressed that he was fighting for a cause; namely, the protection of civilians trapped in a war zone.

Other Malaysians, however, have been inspired to join ISIS due to the appeal of its claim to have established a pan-Islamic caliphate, or the socalled "Islamic State." One such individual was Ahmad Tarmini Maliki, a 26-year-old factory worker who killed himself and 25 Iraqi soldiers on 26 May 2014 with a suicide attack. He was the first Malaysian suicide bomber working for ISIS.

One of the most significant developments pertaining to Malaysians fighting for ISIS has been the formation of an exclusive military unit within ISIS by Malaysian and Indonesian foreign fighters in the Middle East that have joined the group - the Katibah Nusantara Lid Daulah Islamiyyah (The Malay Archipelago Unit of the Islamic State). This unit which aims to bring together the Malay-speaking fighters in ISIS has sparked concerns that alliances and friendships formed there could change the nature of militancy in the Southeast Asian region as these fighters could, on their return to their homes in Malaysia and Indonesia, be able to exploit their combat experience and contacts made while in the Middle East.

A number of Malaysians fighting in Syria and Iraq - both linked with ISIS and those ostensibly fighting for a humanitarian cause - have been openly talking about their exploits in social media in 2014, and their accounts have become resoundingly popular with thousands of Malaysian fans 'liking', commenting, and re-

\section{“ In August 2014, Malaysian authorities also detected a plot by militants carry out a number of attacks..."}

tweeting their Facebook and Twitter posts. Whether by design or happenstance, social media in Malaysia has become a primary source for exposing ordinary Malaysians to the Syrian conflict, and fighters have also used social media to pass on information to interested individuals on how to travel to the conflict zone to join the fight. Besides the online buzz, more traditional forms of spreading jihadist ideology such as radical speeches and sermons have also become more noticeable in Malaysia, with both local and foreign extremist ideologues travelling throughout the country to spread their message.

\section{New Groups}

In late June 2014, citing intelligence sources, Malaysian Press reported on the formation of four new groups in the country referred to only by their acronyms. These four groups were known as: BKAW, BAJ, DIMzia and ADI. The initials 'DI' have been in use for some time in jihadist circles as 'Darul Islam' (State of Islam). There is a likely connection between the four new groups and older groups such as Darul Islam Sabah, which continues to have active elements. Moreover, Malaysian jihadists Amin Bacho and Zulkifli bin Hir (a former leader of Kumpulan Militan Malaysia (KMM), an Al Qaeda affiliated group but now mostly defunct) continue to operate in the Philippines. It is believed that these new groups are linked to existing Malaysian terrorists, and it was revealed that they have set up training camps and safe houses which were discovered in a Malaysian police dragnet operation in mid 2014. These groups are allegedly friendly to ISIS ideology, and wish to set up a Caliphate in Southeast Asia.

In August 2014, Malaysian authorities also detected a plot by militants to carry out a number of attacks targeting the government infrastructure and personnel as well as a disco, pubs, and a Carlsberg (beer manufacturing) factory in Petaling Jaya, a suburb outside of Kuala Lumpur, for being un-Islamic. 


\section{Trusted Al Qaeda Lieutenant}

Before being appointed as AQIS Chief he was AI Qaeda's internet propagandist and also head of Al Qaeda's Sharia committee for Pakistan. He rose in Al Qaeda's ranks after the killing of $\mathrm{Al}$ Qaeda leader Abu Yahya Al-Libi in a 2012 US drone strike. Abu Yahya Al-Libi was the face of Al Qaeda's online propaganda campaign and ran the group's media operations, and Asim Umar filled this position. Reportedly, Ayman AlZawahiri came to know about Asim Umar in 2011 when he was restructuring Al Qaeda, after the killing of Osama Bin Laden. While announcing the formation of AQIS, Ayman Al-Zawahiri mentions that the spadework to launch AQIS was initiated in 2012. He said: "This entity was not established today, but it is the fruit of a blessed effort for more than two years to gather the mujahidin in the Indian subcontinent into a single entity to be with the main group, Qaedat al Jihad."

Before actually joining Al Qaeda, Asim Umar was already well-known to the organisation and a trusted Al Qaeda associate. He first developed relations with $\mathrm{Al}$ Qaeda during his time with HUJI, and won the trust of Al Qaeda leaders when he travelled to Afghanistan for militantcombat training in Al Qaeda-run training camps. It was during this time that he met Osama Bin Laden. Since then, Asim has enjoyed a good reputation with different Al Qaeda leaders, including Osama Bin Laden. According to some media reports, Asim helped Osama to move to his safe house and last abode in Abbottabad.

Asim's ideology is also in line with classic Al Qaeda thinking. In most of his video statements and published works he remains fixated with America ('the far enemy'). In a video statement in 2013, he appealed for global jihad to give a final push to the "collapsing edifice of America." The individuals purportedly involved in the planning of these attacks were among those arrested this year. Other individuals arrested include an architect and a technician, both 26 years old, and a 42 year old shopkeeper at the Kuala Lumpur International Airport (KLIA) on 25 September 2014.

According to the authorities, they were intending to join ISIS in Syria. The three were recruited by a senior Malaysian militant through Facebook, which was followed by meetings with a 'handler' who assisted in planning their trip to Syria. Further arrests in late November 2014 included

\section{"...Indiscriminate law- enforcement targeting could lead to a sense of persecution among the community and could complicate the radical/ extremist environment further in the country."}

an unnamed 36-year-old who had fought in Syria from December 2013 before returning to Malaysia in April 2014, as well as two government employees who is believed to have funded Malaysians going to fight in Syria. Additionally, a number of Malaysian extremists, including Dr. Mahmud Ahmad, an ISIS supporter and former university lecturer, are believed to have found refuge in the Philippines, evidence that regional ties between extremists still exist.

\section{Looking Ahead}

Malaysia has been rigorously vigilant in its response to the increase in extremism in the country. Police have arrested 40 individuals on charges related to terrorism in 2014, and have proposed supplementing the Security Offences (Special Measures) Act - SOSMA, with further legislation to deal specifically with terrorism. SOSMA replaced Malaysia's InternalSecurity Act, and covers national security issues including terrorism. This was announced in the White Paper tabled in Parliament in November 2014. Titled "Toward Tackling the Threat of Islamic State", the White Paper outlined the threat that ISIS poses and the impact it has had on Malaysians, as well as the dangers in allowing its skewed Islamic teachings and violent practices to spread in Malaysia.

The proposed legal measures to deal with the emerging threat in Malaysia includes a provision to allow information from social media to be used as evidence to charge and prosecute individuals with suspected militant inclinations or links. Moreover, also proposed is the establishment of a mechanism, as yet unspecified, to deal with extremist missionaries coming from abroad. 
However, in dealing with the challenges, the Malaysian authorities need to keep in mind the root causes or motivations that are galvanising its citizens to militancy especially after Kuala Lumpur repealed the Internal Security Act either in terms of humanitarian or religio-political issues. It is the latter religious considerations involving the establishment of the Caliphate or an Islamic state by ISIS - which is of much deeper immediate concern. Like in other countries, this has created a mobilization of unexpected proportions among the members of the wider Muslim community as evident from individuals wanting to "migrate" to the Islamic state or to join the fight in Iraq and Syria to defend it. In the Malaysian context, the individuals behind the planned attacks in 2014 appear to belong to this category. At the same time, harsher counter-terrorism measures could stir up more radical sentiments among those who are inspired to join the fight on humanitarian grounds. Indiscriminate law-enforcement targeting could lead to a sense of persecution among the community and could complicate the radical/extremist environment further in the country.

Despite a rather perplexing environment in the country characterised by no major terrorist attacks to date, Malaysia has in the past been used for planning and preparations of some of the most high-profile attacks elsewhere, including the 9/11 attack in New York. Now, Malaysia again seems to be on the crossroads.

Anton Chan is an Analyst with the International Centre for Political Violence and Terrorism Research (ICPVTR) at the S. Rajaratnam School of International Studies (RSIS), NTU. 


\title{
Southeast Asia
}

Stifled from military rule and under international isolation for almost half a century, Myanmar has made significant progress in political reforms since 2011. However, the country now stands at a critical juncture as it confronts three challenging tasks - ensuring a smooth transition to democracy, managing ongoing internal conflicts, and responding to the growing threat of inter-communal violence and trans-national terrorism.

\begin{abstract}
A Stuttering Transition?
Once shattered by army-led isolation, Western sanctions, and long-standing internal conflicts, Myanmar's ongoing political reforms look promising. The country is scheduled to hold multi-party parliamentary elections in 2015. The main contest is likely to be between Aung San Suu Kyi's National League for Democracy (NLD) and the army-backed Union Solidarity and Development Party (USDP). However, some fundamental issues remain unresolved. An amendment of the 2008 constitution is to be expected, and a Parliamentary committee is working on recommendations to be submitted to the Parliament. However, the outcome could only be known six months before the election. The amendment, among other things, will determine the NLD leader Suu Kyi's eligibility for the presidency in the 2015 elections. The constitutional amendment also looks set to determine the degree of autonomy to be given to provincial governments or legislatures. In the past, this has been a major source of friction between the central government and various ethnic groups, often leading to armed rebellion. While these groups have long been demanding a federal form of government, Naypyidaw is in favour of a centralised structure. So far, indications show that any decentralisation of power will be minimal, an outcome which could have a negative impact on ongoing ceasefire talks with the armed groups.
\end{abstract}


Pressure is also mounting on Myanmar's quasicivilian government to carry out the reforms critical for its transition to democracy. While most Western sanctions have been lifted in recognition to the reforms already carried out by the current government led by President Thein Sein, there are accusations of stalling on the rest and even rolling back of some reforms including media freedom and human rights.

\section{Ceasefire Negotiations}

As one of most ethnically diverse countries in Asia, resolving Myanmar's longstanding internal conflicts remains a tremendous task. Though negotiations with the armed groups have progressed, critical challenges remain.

In 2014, Myanmar moved closer to its first-ever Nationwide Ceasefire Agreement (NCA). The NCA, a priority agenda of the Thein Sein government, is critical for ending the six- decadelong civil war and paving the way for political dialogue on ethnic issues.

Negotiations between the government's Union Peace Working Committee and the Nationwide Ceasefire Coordination Team (NCCT) representing 16 ethnic armed groups have been moving forward, albeit with hiccups, particularly on issues involving the scope of future political dialogue and the reform of the armed forces along federal lines. While the priority of the central government remains ceasefire and an immediate restoration of peace, various ethnic groups are interested in working out a long-term political settlement with increased political autonomy. The government has inked ceasefires with 14 of the 16 major armed ethnic groups that comprise the NCCT, but deals with the Kachin Independence Army (KIA) and Ta'ang National Liberation Army (TNLA) in Shan state remain elusive, with KIA frequently clashing with the Myanmar Army in the northern part of the country. The government accuses the KIA of being disingenuous in its pursuit of peace, whilst KIA leaders are doubtful if a ceasefire could lead to greater autonomy which the group is demanding.

Additionally, there are also relatively more powerful ethnic groups, such as the United Wa State Army, that despite having an unofficial truce with the government, are not part of the NCCT and remain outside of the ongoing ceasefire negotiations. Ongoing clashes between the Myanmar army and the some of the groups especially in Karen, Shan and Kachin states in
"... Though

negotiations with the armed groups have progressed, critical challenges remain."

2014 indicate that there are enough spoilers in the overall peace process.

\section{The Rohingya Impasse}

The situation in western Myanmar's Rakhine state remains volatile and deeply scarred by communal riots since 2012 that left over 200 dead and some 140,000 homeless trapped in displacement camps. The situation remains grim for the Rohingya Muslims, with increasing numbers now living in the squalid camps, and many hundreds fleeing the country every day. According to the UNHCR at least 53,000 people have undertaken irregular maritime journeys in the Bay of Bengal towards Thailand and Malaysia, and several hundred have reportedly died during the journey.

Rohingya are not recognised as legitimate citizens of Myanmar both by Myanmar's 1982 Citizenship Law and the Buddhist majority especially in the Rakhine state. In 2014, Rakhine Muslims were mostly missed out of a controversial census - the first in three decades - because of fears that allowing someone to be registered as a Rohingya could amount to recognition of his citizenship which in turn would antagonise the Rakhine majority and further inflame tensions among the rival ommunities. A few days before the census began, Rakhine activists attacked aid agencies running refugee camps accusing them of bias towards Rohingya, and forced the aid workers to flee Rakhine. While many aid groups returned later, conditions in the camps remain dire, particularly in terms of the lack of basic necessities especially healthcare.

The Myanmar government has faced criticism from the international community for not being able to protect the Rohingya from communal violence. The new United Nations Special Rapporteur on the human rights in Myanmar, Yanghee Lee described the situation in Rakhine state as "profoundly disturbing" and called for the adoption of credible measures to reduce tensions and promote reconciliation between the 
Buddhist and Muslim communities. In response, in 2014, the government drafted the Rakhine Action Plan. Though the plan aims to "bring harmony" to the conflict-torn western state, some rights groups have expressed concerns about the possibility of enforced segregation and expulsion of the Rohingya community based on their ethnic and religious identity.

Rohingya-Rakhine relations remain highly volatile and any small incident has the possibility to escalate into large scale violence. In addition there is a growing concern that tensions in the Rakhine state could be exploited by the transnational terrorist groups who are keen to wage an armed jihad against Naypyidaw for failing to recognise and protect its Muslim minority.

\section{The Rise of Buddhist Extremism}

The extremist manifestation of Buddhism in Myanmar, especially since 2012, has led to several bouts of religious violence that have left over 200 people dead and tens of thousands displaced, mainly Muslims. Some radical Buddhist monks have been accused of fanning intolerance by stoking fears of a threat from Islamist militants. Buddhist extremism is gradually escalating to militancy, a trend especially visible in the Rakhine state where a Buddhist militia movement known as the Arakan Army is taking root. The Arakan Army previously had an alliance with the Kachin Independence Army, but of late has disclosed its more hard-line religious stance. It is believed to have more than a thousand heavily armed fighters.

2014 saw a spread of the ideas of the 969 movement - a controversial group of Buddhist monks opposed to what they see as Islam's "expansion" in Buddhist majority in Myanmar. This is evidenced by numerous public meetings by the 969 movement not only in Yangon but across the country. In early October 2014, the website of a popular Myanmar news agency, The Irawaddy, came under 'hacktivist' attack, reportedly by the supporters of the 969 movement.

Though a majority of Buddhists in Myanmar do not support the hate speech spread by the extremists, the narrative is going unchallenged as Myanmar does not have any legal mechanism to prevent inflammatory speech that provokes religious and racial hatred. In addition, politicians as well as policymakers often hesitate to take action against Buddhist monks who are socially embedded and a source of legitimacy, especially
“ Rohingya-Rakhine relations remain highly volatile and any small incident has the possibility to escalate into large scale violence."

at a time when the power relations are shifting. Anti-Muslim hate speech is creating fear, mistrust and resentment within the Muslim community in Myanmar especially among the youth. If left unaddressed, this will eventually become a potential cause of radicalisation that the Islamist extremists could exploit.

\section{Threat of Terrorism}

The terrorist threat in Myanmar has escalated significantly since the 2012 Muslim-Buddhist riots in its western region which later spread to its central and north-eastern regions. The communal violence, coupled with the rise of Buddhist extremism, has created a shared sense of victimhood among the Muslim minorities in Myanmar. The sense of Muslim victimhood is being exploited by the jihadist groups in the region and beyond. Since June 2012 there has been a plethora of statements posted in social media platforms depicting the plight of the Rohingya which has caused numerous terrorist groups to the desire to conduct armed jihad in Myanmar. Several radical groups operating in South Asia, Central Asia and Southeast Asia including the Tehreek-e-Taliban Pakistan (TTP), the Afghan Taliban, the Islamic Movement of Uzbekistan (IMU), and the Jama'ah Ansharut Tauhid - are using the Rohingya issue to incite members of the Muslim community.

The TTP especially has been playing a key role - patronising Tehrik-e-Azadi Arakan (TAA) - a group comprising Rohingya living in Pakistan, and providing training, including the making and use of IEDs and VBIDs, to its members. TAA has been recruiting its fighters mostly from Karachi reportedly a stronghold of the Rohingya Solidarity Organization (RSO), a group which had extensive links with AI Qaeda (now being referred to as $\mathrm{Al}$ Qaeda Central). 
TAA carried out attacks in Afghanistan-Pakistan border areas in November 2014. Bangladeshi authorities arrested three Rohingya from Dhaka for their alleged links with suspected Jama'atul Mujahideen Bangladesh (JMB) operatives. Five detonators, two bombs and explosives were seized from their possession. Also, in the same month, Indian authorities arrested a Myanmar national for his alleged links with the TAA. Incriminating videos, training manuals, and jihadist literature including Islamic State group's literature were found from his possessions.

Additionally, Al Qaeda Central has also turned its attention to Myanmar, especially after the September 2014 announcement of the establishment of Al Qaeda in the Indian Sub-continent (AQIS). AQIS identified Myanmar as one of their main focus areas, alongside India and Bangladesh. One of the major strengths of AQIS is AI Qaeda Central's old links with diverse groups in South Asia and Southeast Asia. This could enhance the reach and lethality of Rohingya in Myanmar. Significant numbers of AQIS propaganda materials have been translated into the Burmese language and disseminated in 2014, which indicates recognition of the disaffected Rohingya as a potential pool of recruits. In addition to these threats, there also have been unconfirmed reports about the emergence of a new group called Myanmar Muslim Army (MMA), which is reportedly using Thai territory for training Myanmar Muslims.

\section{State Response}

On 4 June 2014 the bicameral union Parliament passed the country's first Anti -Terrorism law. The law carries a minimum 10 years and a maximum of life imprisonment or death penalty for acts of terror. Since the law was passed, authorities have arrested 36 people suspected of terrorism activities, though no details about the persons involved or their activities leading to the arrests have been given. Myanmar also plans to set up a central counter-terrorism body, the first of its kind in the country focusing on specific areas such as chemical attacks, combating terrorism financing and gateway security.

\section{Looking Ahead}

In the run up to the 2015 elections, there are three challenging tasks ahead for Myanmar. These are: ensuring a smooth transition to democracy, managing ongoing internal conflicts, and responding to the growing threat of inter-communal violence and transnational terrorism. It remains to be seen how a country, transiting from decades of authoritarian rule to democracy fares in dealing with the threats from the complex ethnic and religious challenges that underlie various conflicts in the country leading to political violence, terrorism and extremism.

Iftekharul Bashar is an Associate Research Fellow with the International Centre for Political Violence and Terrorism Research (ICPVTR) at the S. Rajaratnam School of International Studies (RSIS), NTU. 


\section{Southeast Asia}

\section{Philippines}

Anton Chan

In 2014, one of the most important terrorism related incidents in the Philippines was the kidnapping and subsequent release of two German tourists by the Abu Sayyaf Group (ASG), which has retained its notoriety despite government efforts and U.S. assistance against the group. Despite a significant decline in its membership due to the government's sustained offensive against the group, ASG continues to stage audacious kidnappings. The United States also announced in 2014 that it would be deactivating the personnel in its Joint Special Operations Task Force Philippines, or JSOTF-P, which had been established since 2001 to help the Armed Forces Of the Philippines (AFP) fight the group. Additionally, the Bangsamoro Islamic Freedom Movement (BIFM) is also proving to be increasingly bothersome, especially in the context of its opposition to the peace agreements between the government and Moro Islamic Liberation Front (MILF). The peace talks between the Philippine government and MILF remain on track, notwithstanding opposition from the Moro National Liberation Front (MNLF). Additionally, the Communist Party of the Philippines (CPP) and its armed wing, the New People's Army (NPA) continued to pose threats to peace and security in the country.

While these issues reflect the characteristics and trends of the traditional conflicts in the Philippines, the impact of the declaration of a Caliphate by the Islamic State of Iraq and Greater Syria (ISIS) has added a new dimension to terrorism in the country, with a number of groups and individuals publicly pledging their allegiance, especially on social media platforms. The possibility of Philippine nationals travelling to the Middle East to participate in conflicts there has also kept the country on its edge. 


\section{Bangsamoro Peace Process: Actors and Spoilers?}

Negotiations between representatives of MILF and the government of the Philippines progressed with the signing of the landmark agreement - the Comprehensive Agreement on the Bangsamoro (CAB) - on 27 March 2014. Following up on the agreement, on 10 September 2014, the government submitted the draft of the Bangsamoro Basic Law (BBL) to the Philippines Congress. As the legislative process takes its own course, the parties involved remain hopeful that the passing of the BBL through a plebiscite, followed by the creation of the Bangsamoro Transition Authority (BTA) formalising autonomy for Mindanao - for one year to start with - could be accomplished before President Benigno Aquino's term ends in 2016.

The proposed Bangsamoro political entity will replace the existing Autonomous Region of Muslim Mindanao (ARMM), which was created in 1996 under a separate peace agreement with the MNLF. This however has created a rift between the government and the MNLF, due to perceived marginalisation and dispossession of authority of the latter, especially its erstwhile leader and former governor of ARMM, Nur Misuari. MNLF has itself been split on this issue with large scale violence perpetrated by the Nur Misuari faction in Zamboanga City in late 2013.

After a series of negotiations however, in November 2014, both the Moro groups met in Manila as part of the 'MILF-MNLF Bangsamoro Coordination Forum (BCF)', brokered through the Organization on Islamic Cooperation (OIC). BCF was formed to "provide a venue to find common ground between the 1976 Tripoli Agreement, 1996 Final Peace Agreement with the MNLF and the Comprehensive Agreement on the Bangsamoro (CAB)" with the MILF and to coordinate the efforts of MILF and MNLF towards achieving a political solution to the decades long conflict with 'lasting peace and inclusive development' for the Bangsamoro people. In a communiqué issued on 17 November 2014, both the parties affirmed their commitment to harmonise the two peace tracks and work together for the resolution of the conflict in southern Philippines. It was also proposed to establish an Executive Bureau and a secretariat of the BCF to institutionalise these initiatives which also include joint efforts involving "da'wah and education, shariah, economy, natural
"Even as the Philippines government made significant progress towards a peaceful resolution of the Moro conflict, there is still a concern that the peace process could be derailed by rogue elements..."

development."

Even as the Philippines government made significant progress towards a peaceful resolution of the Moro conflict, there is still a concern that the peace process could be derailed by rogue elements of MILF - BIFM and by the ASG. Hence operations against both the groups have continued with the same vigour as before.

\section{Abu Sayyaf Group}

The ASG continued its kidnapping operations with more cross-border raids, with its operatives travelling by boat to the resort islands in neighbouring East Malaysia (Sabah) to kidnap individuals, mostly tourists, bringing the victims to the Philippines, and demanding ransom for their release. On 2 April 2014, Abu Sayyaf gunmen raided a Malaysian resort in Semporna, kidnapping a tourist from the People's Republic of China named Gao Huayuan and a Filipina resort employee named Marcy Darawan.

Both were released on 31 May 2014. In two separate incidents on 6 May 2014 and 16 June 2014 respectively, ASG also abducted two Malaysian-Chinese fish farm managers Yang Zai Lin and Chan Sai Chuin from East Malaysia. In these incidents too, both were released after negotiations with the group. Although the Philippines government generally does not admit to payment of ransoms for release of hostages, it is likely that ransoms were paid in these cases. 
Learning from these examples, ASG has found that ethnic Chinese - regardless of nationality - are tempting targets as the victims and their families tend to pay larger ransoms rather quickly, making them profitable choices for kidnapping. Later in the year, the Chinese government warned its citizens against travelling to the Philippines after another Chinese, $\mathrm{Li}$ Peizhi, a teenager, was kidnapped from his family-owned store in Zamboanga in the southern Philippines.

The biggest windfall for the ASG, however, is likely the ransom of approximately US\$ 5.6 million that was demanded for the release of two German hostages, Stefan Viktor Okonek and Henrike Dielen. Again, official sources did not state that any ransom was paid for their release, but ASG claimed that it had received the ransom in full, and even posted a photograph online of a militant posing next to stacks of 1,000 note peso bills, indicating that a ransom was indeed paid. It was also claimed that the price of fire arms on the Philippines black market increased after the release of the two Germans, due to the shortage of supply caused by large purchases made by ASG using the ransom money.

Since October 2014, the government has intensified its offensive against the ASG targeting its strongholds in Sulu and Basilan. The government has formed "Joint Task Groups" for both the areas to execute its operations against the group with a decisive punch, especially in the context of the end of the U.S. Special Forces support for actions against ASG in terms of logistics, training and intelligence. The U.S. reduction of its forces in the JSOTF-P is due to a justified belief the AFP is now quite capable of dealing with ASG. The operations against the group resulted in significant casualties involving the ASG, and the ensuing turmoil also enabled long-time Swiss captive Lorenzo Vinciguerra to escape from his captors.

The Armed Forces of the Philippines targeted BIFM through "Oplan Dark Horse" (Operation Dark Horse), launched in January 2014 which led to the capture of large numbers of its fighters and destruction of a number of its bases and camps including the group's main stronghold in Barangay Ganta, Shariff Saydona Mustapha in Maguindanao province. However, the BIFM continues the fight with attacks targeting members of the security forces.
"The rise of the ISIS has also affected the Philippines, with a number of videos emerging on social media such as You Tube featuring senior members of local groups and others individually or collectively pledging allegiance.

\section{ISIS Effect in the Philippines}

The rise of the Islamic State of Iraq and Greater Syria (ISIS) has also affected the Philippines, with a number of videos emerging on social media such as Youtube featuring senior members of local groups and others individually or collectively pledging allegiance to ISIS. On 23 July 2014, a senior leader of the ASG, Isnilon Hapilon, featured in a Youtube video reading a pledge of allegiance to ISIS with a number of militants. Additionally, in the high profile kidnapping of the two Germans, the ASG not only demanded a payment of ransom money, but also threatened that the hostages would be executed if Germany did not stop its assistance to the U.S.-led coalition against ISIS. However, the fact that the hostages were released without Germany giving any commitment for staying away from the coalition indicates that the ASG is most likely disingenuous in resuming the pursuit of a jihadist agenda, and has merely been riding on the popularity of ISIS to seek support from fellow militants. The Bangsamoro Islamic Freedom Fighters (BIFF - the armed group of BIFM) also pledged its allegiance to ISIS and its leader Abu Bakr al Baghdadi. In a statement, BIFF spokesperson- Abu Misry Mama also stated that if ISIS needs, BIFF would be ready to help to send its members to protect the Islamic 
state. However, there has been no evidence of direct involvement of any member from the two groups with ISIS activities or vice versa so far. In 2014, the Philippines government maintained a low profile with no evidence of any strong measures in dealing with the impact of ISIS. The government's stand has been that reports of oath taking are unconfirmed, and that 'further investigations' need to be carried out to ascertain the influence of ISIS on local groups and individuals. The claim by former Filipino President Fidel V. Ramos that up to 100 Filipinos have trained with ISIS was also quickly dismissed by the authorities. There were however reports indicating deaths of Filipino fighters who were in combat in Syria. According to the Embassy of the Philippines in Damascus, information was provided by the Syrian government that two Filipinos were killed while fighting against the Assad regime. The Iranian Fars news agency (FNA) also identified another fighter from the Philippines - one Abo Ahmad Shiko - who had lost his life in the fight against the Assad regime.

\section{Communist Party of the Philippines}

Despite Manila's best efforts, the Communist Party of the Philippines' New People's Army (CPP-NPA) continued its 45 year-long insurgency in the country. According to Public Affairs Office of the AFP, CPP-NPA strength reduced to 3200 from 4000 in 2014, the group's lowest reported numbers since the beginning of the insurgency. Additionally, the arrest of CPP leaders - Chairman Benito Tiamzon and his wife, the party's Secretary General Wilma Tiamzon - in March 2014, was a blow to the organization's leadership.

The government has been in peace talks with the group but without any meaningful progress. Talks are likely to resume in 2015, but the pace and progress of the same would depend on government's response to the demand for the release of the Tiamzons. The CPP-NPA did however, announce its customary Christmas truce with the military, and a further period to last until the end of the Catholic Pope's visit to the Philippines from 15 to 19 January, which passed without incident.

\section{Looking Ahead}

To be sure, there is a positive outlook for the Philippines with the government remaining engaged in peace talks with the MILF and MNLF and the CPPNPA. However, the ASG and BIFM would continue to be the spoilers for ending age-old conflicts and establishing platforms for durable peace in the country. Ultimately it depends on the government to sustain the peace initiatives and at the same time deal with renegades and the radical elements especially the ASG and the BIFM/BIFF. Additionally, clashes between security forces and the MILF/MNLF such as occurred on 25 January 2015 could also act as road-bumps and should be avoided. A self-governing authority, established in accordance with the Bangsamoro agreement, might be able to deal with challenges at the local level. However, the government must ensure that the agreement gets legislative approval and institutions pledged therein are in place within the scheduled time frame. This is something that has failed the peace initiatives in the past, especially in respect of 1996 peace deal with MNLF, and hopefully will not be repeated.

Anton Chan is an Analyst with the International Centre for Political Violence and Terrorism Research (ICPVTR) at the S. Rajaratnam School of International Studies (RSIS), NTU. 


\section{Southeast Asia}

\section{Thailand}

Anton Chan

Thailand ended almost half a year of political upheaval on 22 May 2014 when the military junta under Prayuth Chan-ocha took power. The Prayuth government inherited a broken peace process in Southern Thailand, and an ongoing insurgency that entered its eleventh year with no end in sight. Muslim insurgents in the four southern provinces of Yala, Narathiwat, Pattani, and to a lesser extent, Songkhla, continued their struggle against the Thai government with the goal of achieving independence from Thailand. On the ground, however, it appears that many of the individual attacks are not part of a grand strategy, but rather are reactive. Attacks may be triggered by actions from security forces, whom insurgents feel act with impunity against the local populace, and the insurgency itself remains fuelled by day to day difficulties in the social and economic sphere. Deaths from the conflict since 2004 reached over 6,200 in November 2014, and the new military government in Bangkok has tackled the insurgency by introducing tighter security measures, which in the past have always been counterproductive. Meanwhile, Malaysia continued to work with the Thai government, acting as a facilitator in the peace process.

\section{Tactics and Targets}

Similar to 2013 , the trend of attacks continued to remain the same targeting the security forces and paramilitary defence volunteers. Attacks on children and a number of 'revenge' attacks on civilian targets have also occurred.

On 3 February 2014, three young brothers were killed and their parents wounded when gunmen fired at the family after they returned home from evening prayers at the local mosque. The ambush in Bacho district, Narathiwat, left the three boys dead, and their parents injured. The gunmen had been hiding in a nearby forested area and waited for the family to return to their home before opening fire at them with automatic weapons. Investigations revealed that the attack was committed by two members of the 
paramilitary forces who held a grudge against the boys' father who was a former insurgentturned informant. The killing of the three brothers was followed by a small wave of revenge attacks by insurgents in Narathiwat and neighbouring provinces. On 9 February 2014, a policeman's wife was gunned down and her body set on fire in public. A note was left on her body, saying that the killing was revenge for the killing of the three brothers. Two similar attacks occurred soon after. On 12 February 2014 the burned body of a 29 year old female bank employee was discovered with a note addressed to then-Thai Army Chief Prayuth Chan ocha saying "this is not the last body after the three brothers." She too had been shot and then burned after having her body doused in petrol. A month later, two more attacks occurred in which the victims' bodies were burned. This trend of 'tit for tat' attacks continued later in 2014, with messages being left at the scenes of insurgent attacks on their victims, expressly attributing the cause of the killings to what they saw as indiscriminate actions by security forces.

2014 also saw a large number of attacks using Improvised Explosive Devices (IEDs), as insurgents moved from carrying out attacks in the provinces to attacks in urban areas. On 6 May 2014, insurgents carried out a well orchestrated attack in the city of Hat Yai, Songkhla province. Five IEDs were planted, four of which were detonated successfully, resulting in injuries to 10 people. The identity of perpetrators is not known and as is common, no particular group took responsibility for the attacks. An explosive also went off outside the Holiday Hill Hotel, an area frequented by Malaysian tourists, in the Betong district, Yala province on 25 July 2014, killing two people and wounding 52 more. Multiple bombings were carried out on 31 October 2014 at four different karaoke restaurants in Pattani's Muang district, resulting in the death of a waitress of Lao nationality. The choice of targets highlights that the attacks were meant to discourage Muslims from visiting locations of ill repute.

The southern Thai insurgency remains a nebulous phenomenon, with small cells on the ground acting more or less independently of a nominal leadership from a previous generation of militants in exile with waning authority. This makes attacks difficult to predict or control. However, in July 2014, unconfirmed reports emerged that talks between the insurgents and eight core Barisan Revolusi Nasional (BRN) members were taking place at a mosque in
“ 2014 also saw a large number of attacks using Improvised Explosive Devices (IEDs), as insurgents moved from carrying out attacks in the provinces to attacks in urban areas."

Pasemas of Kelantan state, Malaysia, to plot simultaneous terror attacks in the three restive Thai provinces. The group apparently planned to use about 150 militants from the Runda Kumpulan Kecil (RKK or small action group) to carry out gun and bomb attacks in areas outside Muang district in Yala province, in areas in Muang municipality, Pattani, in the municipal areas in Muang district and in other outlying districts in Narathiwat. It is however, not known if attacks that followed this supposed meeting were indeed orchestrated by these individuals.

\section{Military Rule, the Southern Insurgency and Restarting the Peace Process}

Historically, there has been a deep sense of distrust between the Muslims in the southern provinces and the Thai military, which worsened in 2004 with the killings of Muslims at Krue Se Mosque (April 2004) and Tak Bai (October 2004). Southern Thai Muslims also blame the military for continuation of the emergency decree in the provinces. This makes it quite difficult for the current government under ex-Army Chief Prayuth Chan-ocha to deal with the insurgency with a hearts and mind approach including through peace negotiations.

Despite the complexities involved, the Prayuth government appears to be committed to to reignite the peace dialogue set in motion by the previous governments. Prime Minister Prayuth has discussed the southern situation numerous times, and while the government has not yet officially restarted the talks, it has reiterated its willingness to do so and apparently preparing the groundwork for the same. Prime Minister Prayuth also visited Malaysia with a high level team of officials on 1 December 2014, with the 
announced intention of discussing how to move forward with the peace talks, with Kuala Lumpur continuing to act as facilitator.

\section{Concerns beyond the Deep South}

Thailand is also experiencing threat of terrorism from other groups, especially in Bangkok. Thai authorities arrested two Hezbollah militants planning to attack Israeli and other tourists in Bangkok's popular backpacker area Khao San road in mid April 2014 during the Thai New Year - Songkran. Involved in the plot were French-Lebanese national Daoud Farhat and Lebanese-Filipino national Youssef Ayad, who arrived in Thailand several days before the Songkran festival began on 13 April 2014. However, the Thai authorities were able to arrest the would-be perpetrators and prevent the attacks with intelligence provided by Israel. A third suspect - Bilal Bahsoun - however eluded the Thai authorities. Hezbollah operatives have operated in Bangkok in the past which was highlighted in attempted attacks in Bangkok in 2012.

Additionally, human trafficking and illegal flow of refugees especially those involving the Uighur from China's Xinjiang province and Rohingyas from Myanmar have become issues of serious security concern for Thailand. Due to harsh crackdown by respective governments, both the Uighur and the Rohingyas have been fleeing from their homeland - sometimes on their own or being smuggled out by the human smuggling rings operating in the region. In March 2014, Thai authorities pulled more than 100 Uighur from a human smuggling ring. Later they were found to be missing from the shelter where they were put up and believed to have fled to make their way to Malaysia. A number of Rohingya and Bangladeshi refugees have been attempting to enter the region through Thailand as the country sits along the regional human trafficking routes

\section{Looking Ahead}

With no solution in sight, the insurgency in southern Thailand will continue further. The government, whether under a civilian or military leadership, has consistently failed to address the underlying issues. Instead it invariably comes out with short-fix measures that fail to inspire confidence among the Southern Thai Muslims and become counterproductive. Political instability in Bangkok has been derailing almost all attempts at reconciliation through negotiations. Malaysia does have a significant role in bringing the conflicting parties to the negotiating table, but overall geopolitical concerns on the part of the Thai government and distorted perceptions and disagreements among the southern Thai militants have been preventing this to happen. Mostly, the southern Thai conflict will remain relegated to the back as long as Bangkok remains unstable - oscillating between democratically installed governments and military rule.

Anton Chan is an Analyst with the International Centre for Political Violence and Terrorism Research (ICPVTR) at the S. Rajaratnam School of International Studies (RSIS), NTU. 


\section{Southeast Asia}

Even though there were no terrorist attacks in the country, Singapore continues to be a target of the threat of radicalisation and extremism especially after the emergence of the Islamic State of Iraq and Greater Syria (ISIS). This prompted the government to raise the threat level, putting its security apparatus in a heightened state of alertness. While continuing to collaborate with neighbouring countries against the threat of terrorism, Singapore has also pledged its support to the international fight against ISIS.

\section{Singaporeans Fighting in Syria}

In October 2014, Deputy Prime Minister Teo Chee Hean stated that there are at least two Singaporeans that have travelled to Syria to participate in the conflict. One is Haja Fakkurudeen Usman Ali (Haja), a naturalised Singapore citizen of Indian origin. Haja, a 37-year-old supermarket manager, is believed to have been radicalised by Gul Mohamed Maracachi Maraicar, an Indian national and a former Singaporean Permanent Resident, who worked as a systems analyst in a multinational company. Gul was investigated and deported from Singapore terminating his PR status in Singapore. However, no action could be taken against Haja as he is believed to have left Singapore in November 2013 for the Middle East, taking his wife and three children with him. The second Singaporean is a 47-year-old woman who went to Syria with her Malaysian husband, son and daughter from a previous marriage, believed to be 14 and 18-years-old respectively. According to reports from the Malaysian press, the family traveled to Syria in November 2014, but did not stay together. The husband is believed to have joined the Al Qaeda-linked Jabhat al Nusra group in Syria, while the son is believed to have joined ISIS. The woman involved has allegedly been working as a cook, while the daughter has been teaching English to the children of other fighters in Syria, but information on their group affiliations has not been made public. 
The government has reiterated its resolve to deal decisively with individuals that pose a threat to the country, especially those who assist, support, promote, or join violent organisations like ISIS which have demonstrated a tendency towards the use of extreme violence and brutality. As stated by DPM Teo Chee Hean, such persons pose a "real threat to Singapore's national security, and will be dealt with in accordance with our laws".

\section{Singapore in the Fight against ISIS}

In December 2014, the government of Singapore announced that it would be sending a team of 50 to 60 Singapore Armed Forces (SAF) personnel to Iraq to join the coalition efforts against ISIS. As with previous deployments to Afghanistan, the units will not engage in front line combat roles, but provide a supportive role through the provision of an air-to-air re-fuelling tanker as well as an imagery analysis team.

While in Naypyidaw, Myanmar, for the East Asia Summit (EAS), the Prime Minister of Singapore Lee Hsien Loong proposed the creation of an East Asia Summit symposium to tackle religious extremism, a subject which Singapore actively pursues in conducting its own deradicalisation programs involving psychological, religious, and social counselling for detainees incarcerated for their links to terrorism and extremism. Singapore will host the East Asia Summit Symposium on 'Rehabilitation and Reintegration' on 16-17 April, 2015, supported by Singapore's Ministries of Foreign and Home Affairs, and the Religious Rehabilitation Group (RRG). The symposium will focus on identifying best practices for deradicalisation, rehabilitation, and reintegration of fighters returning from Syria and Iraq.

\section{Looking Ahead}

While no terrorist groups are known to be actively operating in Singapore, the general trend of a rise in extremism in the region and beyond affects the country significantly. However, Singapore will continue to deal sternly with extremism and terrorism with the "whole of government" approach encapsulated as "total defence" as in the past which has been useful not only to prevent any terrorist attacks in the country but also keeping the country in a state of perpetual readiness to deal with the consequences of the same if an attack takes place.

Anton Chan is an Analyst with the International Centre for Political Violence and Terrorism Research (ICPVTR) at the S. Rajaratnam School of International Studies (RSIS), NTU. 


\section{South Asia}

\section{Afghanistan \\ Halimullah Kousary}

In 2013, the Afghan National Security Forces (ANSF) took over security responsibility from NATO-led International Security Assistance Force (ISAF). ANSF now leads all military operations against the Taliban. In 2014, Afghanistan held its third presidential election with overwhelming participation of Afghans across the country despite Taliban threats and attacks. The election resulted in the first ever-peaceful transfer of power in the history of the country demonstrating a level of maturity in Afghan politics. However, these developments did not make any dent on the Taliban-led violence in the country.

\section{Enduring Taliban influence in Afghanistan}

Since mid-2013, the Taliban has initiated an ambitious shift in their military campaign. Assisted by their foreign associates, the Taliban launched offensives involving groups of 500 to 1,000 fighters in several provinces of the country, with a view to capture and control territory. The provinces include Helmand and Kandahar in the south, Kunar Nuristan, Nangarhar and Logar in the east, Badghis and Herat in the west and Badakhshan in the northeast. Six of the nine provinces share the border with Pakistan. This continued in 2014 as well, facilitated by the formal end of combat missions both by the U.S. and NATO in December 2014, with the latter transitioning to a training and support role for the Afghan security forces.

Under their new President - Ashraf Ghani Ahmadzai - the new Afghan government signed the Bilateral Security Agreement (BSA) with the U.S. and Status of Forces Agreement (SOFA) with NATO on 23 November 2014. 
While these agreements signify Afghanistan's continued engagement with the International Community in security matters, without which it would be difficult for the Afghan security forces to stand their ground and face a determined militant force, the continued footprints by the U.S. and NATO also remain a strong catalyst for the Taliban to carry on their fight. In the months following the signing of the agreements, the Taliban increased its offensives including a bloody campaign of suicide operations across the country. Reuters has reported that nearly 3,200 Afghan civilians were killed in the conflict between the militant group and the army in 2014, and more than 4,600 Afghan army and police died in Taliban attacks. Accordingly, President Ashraf Ghani's top priority will be keeping government control of territory and preventing security from further deteriorating in 2015.

\section{Regional Interests at play in Afghanistan}

One major failure of the U.S. in the region has been its inability to prevent the India-Pakistan rivalry affecting the fight against the Taliban in Afghanistan. Divergent interests of the two countries hindered progress and shaped a regional dimension to the Taliban insurgency. Rivalries with India have formed Pakistan's view of the Taliban as a strategic asset; and Islamabad's paranoia about India's growing influence in Afghanistan has been used to justify its support for Taliban as a counterweight.

Kabul has made all attempts to keep the IndiaPakistan rivalry and fight against the Taliban apart by maintaining a balance in its relationships with both India and Pakistan. A month into office, on 14 November 2014, President Ashraf Ghani made his first visit to Pakistan in a bid to build mutual trust between the two countries. He also visited China, and some analysts have seen this step as attempting to befriend China in order to leverage on its influence on Pakistan as well as a generally more balanced foreign policy approach. His predecessor, President Karzai had made 20 visits to Pakistan for the same purpose, but with little effect. Despite these initiatives however, Pakistan continues to be ambivalent about its relations with the Taliban, justifying its interactions with the later on the basis of what Islamabad calls "good and bad" Taliban. This is evident from the fact that following President Ashraf Ghani's visit to Pakistan, Sartaj Aziz, Pakistan's advisor on national security and foreign affairs, argued that Islamabad has no
"In the long term, economic development in Afghanistan and economic integration in the broader region is fundamental to fighting the Taliban and by extension, the broader militancy in the region."

reason to antagonise groups that pose no threat to Pakistan, describing the Afghan Taliban as the enemy of Afghanistan and the US instead. At the same time, Afghanistan stressed the need that Pakistan's most recent military operation Zarb-eAzb be targeted at all militant groups based in North Waziristan. On the contrary, 'Zarb-e-Azb' was purportedly designed to target the Pakistani Taliban and foreign militant groups seen as threat to Pakistan and China such as Islamic Movement of Uzbekistan, East Turkistan Islamic Movement (ETIM) and AI Qaeda. India-Pakistan rivalry has also affected the fight against the Taliban on the economic front. In the long term, economic development in Afghanistan and economic integration in the broader region is fundamental to fighting the Taliban and by extension, the broader militancy in the region. But this has not been the case so far.

It was evident from the fact that at the 18th SAARC Summit of the South Asia Association for Regional Cooperation (SAARC) on 26 November 2014 in Kathmandu three agreements on connectivity and energy cooperation failed to be adopted by the member countries. Pakistan was unwilling to sign the agreements and this brings up the question whether important economic developments such as the TAPI pipeline project (Turkmenistan-Afghanistan-Pakistan-India) are feasible in the current geopolitical context. After the vicious Pakistani Taliban attack on an armyrun school in Peshawar on 16 December 2014, it was hoped that Pakistan would bring a change in its policy towards the Afghan Taliban and targeting Afghan Taliban leaders who base 
themselves along the Afghanistan-Pakistan border. However, government efforts continued to remain focused only against the Pakistani Taliban. It has tried to leverage the school attack to mount pressure on Afghanistan and show the world that it too is subjected to terrorism with external support. At the same time, Pakistan claims that it sees militants of all hues as a threat to the region. If true, this should lead Islamabad to target Afghan Taliban sanctuaries, dismantle their structure in Pakistan and bring them to the negotiation table with the Afghan government.

\section{Transnational Dimensions to the Conflict in Afghanistan}

Afghanistan-Pakistan has remained a strategic region in the history of Islamist power struggle. During the Afghan jihad in 1979, Islamists from across the world poured into Afghanistan and Pakistan to fight against the Soviet Union, empower an Islamic rule in Afghanistan and then expand it to other Muslim countries in the world. Al Qaeda owes its origin and spread to the Soviet occupation of Afghanistan and its aftermath - the fight by the "mujahideen," against the occupation of Afghanistan followed by extreme neglect of the country by the international community, especially the U.S., after the Soviet Union retreated. While al-Qaeda was the previous product of this phenomenon, the recent dramatic rise of the Islamic State in Iraq and Syria (ISIS) is the newest, largest threat group in the region and AfghanistanPakistan is susceptible to its presence. Already, there have been reports of fissures in the Taliban movement, with reports emerging of at least one former Taliban commander - Mullah Abdul Rauf Khadim - possibly having switched allegiance to ISIS and attempting to recruit on their behalf.

The rise of the Islamic State in Iraq and Syria (ISIS) is also important from an Afghan perspective. It has led to a discourse on the typology rather than the essence of Islamist factions. However, whether pledging allegiance to Abu Bakr al Baghdadi or Mullah Omar the primary issue remains a revival of Islamist supremacy in the Muslim world and a sense of shared goals among Islamist militants whether transnational or local. Other than the sense of a shared goal, what else makes Afghanistan-Pakistan region vulnerable to increasing influence of Al Qaeda and ISIS is the existence of the common enemy - the U.S. and its Muslim allies in the region.

Therefore, as the conflict in Afghanistan-Pakistan region lingers on, it will likely draw in the involvement of transnational terrorist organizations like ISIS and Al Qaeda. While the Afghan Taliban ought to be perceived as a rival of ISIS as both claim leadership of the Muslim Ummah, some Taliban elements have reacted to it with a welcoming tone. Reports suggest that elements in the Afghan Taliban launched operations in the name of ISIS in parts of Afghanistan. This came as some commanders of TTP in Pakistan's FATA region welcomed ISIS campaign while others pledged allegiance to it. If ISIS is able to persist, it would most likely further trans-nationalise local conflicts, affecting the security of Afghanistan in its wake.

\section{Looking Ahead}

Group attacks by the Taliban assisted with manpower by foreign militant factions in 2014 are an indication of a more ambitious military campaign to wage a protracted insurgency in Afghanistan in the years to come.

Halim Kousary is the Deputy Head of Research at the Centre for Conflict and Peace Studies (CAPS), Kabul, Afghanistan. 


\section{South Asia}

\section{Bangladesh}

After remaining dormant for a couple of years, Islamist militant outfits in Bangladesh are showing sign of revival in 2014 indicating their resiliency to adapt in an unfavourable environment and out-manoeuvre the government crackdown. The groups like Ansarullah Bangla Team (ABT) have been making sophisticated use of propaganda largely through online social media to reach their audience. This gave them an opportunity to spread their ideology and to reach out to potential pool of recruits while maintaining a low profile. Some militant outfits have been recruiting youths in large numbers from the mainstream educational institutions. This is in contrast to the prevailing practice of recruiting from madrassas.

Secondly, most of the groups continued to indoctrinate their cadres through study circles and prepare them for combat through training. Some outfits opted for small scale target killings often with locally made weapons.

In 2014 at least 35 militants have been arrested and substantial quantity of arms, explosives, detonators, bomb making manual and extremist publications has been seized from them. The interrogation of the militants demonstrated the capability and preparedness of the groups to carry out major attacks in the country.

\section{Harkat-ul-Jihad Al Islami Bangladesh (HuJI-B)}

At least 13 militants from the HuJl-B were arrested in 2014. Sophisticated remote control devices, and detonators have been recovered. The Bangladeshi authorities have unearthed a laboratory which HuJI-B was using to develop powerful explosives. Investigations reveal that HuJI-B is capable of using remote-controlled bombs to assassinate important personalities. 
The HuJI-B is one of the oldest Islamist militant group in Bangladesh. Founded in 1984 by the Bangladeshi veterans of the Soviet-Afghan war, the group went through several phases of evolution and took its current shape in 1990. In 1992 the group publicly announced that it aims to wipe out democracy and establish a Talibanstyle regime in Bangladesh through armed jihad. The group is known to have links with Pakistan based militant groups like Lashkar-e-Taiba and Jaish-e-Muhammad. It has links with some Kashmir based groups in India also. The group currently operates in Dhaka division mostly in Gopalganj, Narayanganj, and Jamalpur district. The group is suspected to have links with $\mathrm{Al}$ Qaeda.

\section{Jamaatul Mujahideen Bangladesh}

At least $15 \mathrm{JMB}$ members have been arrested by the Bangladeshi authorities in 2014. Powerful explosives of new kind as well as bomb-making equipment were seized. For the first time two financiers of JMB were arrested. They provided money for hijacking convicted militants from a police van earlier in February 2014. Bangladeshi authorities have found a linkage between this hijack with the 2 October blast in Burdwan, West Bengal, India.

Some of the key leaders of JMB are currently hiding in India's West Bengal and Assam state. From there they have been trying to reorganise their outfit. Now they are also active in areas like Sylhet, Hobigonj, Bagerhat, Satkhira, Barguna, Jamalpur, Narayanganj, Tangail, Mymensingh, Gazipur, and Comilla districts.

Founded in 1998 by some of the followers of Ahle Hadis (Salafi) Movement, JMB aims to impose a rigid, extremist interpretation of the Islamic Law on Bangladesh. To achieve this end, it sought to undertake terrorist activities to undermine the authority of the state. JMB carried out a spectacular attack in 17 August 2005 when it exploded 510 bombs within a span of less than an hour throughout Bangladesh. In recent years the group is found to be decentralising its command structure by establishing independent cells.

\section{Ansarullah Bangla Team}

At least 5 members of ABT have been arrested in 2014. Created in 2011, this group adheres to Al Qaeda's ideology and remains directly linked with Al Qaeda in Arabian Peninsula (AQAP).

\section{“ Currently, all the militant organisations are trying to form a common platform called the "Bangladesh Jihadi Group'."}

At present the group is active in southern coastal area of Bangladesh and Dhaka metropolitan area. The group is using female activists to collect funds for their activities. In 2014, the group assassinated a professor of university for his views on religious issues. Earlier in 2014, the ABT also assassinated a Muslim cleric.

The group has conducted targeted killings by small cells, most likely due to their limited operational capabilities. There is also a possibility that the group wants to remain a lowprofile so as to avoid the radar of law enforcement agencies. This group is also active in the Internet. The group uses web resources to recruit members as well as to identify their targets. They are recruiting mostly from the highly educated youth from the mainstream universities. The group's members are preparing to go to Iraq and Syria. This group is in touch with a number of Bangladeshi diaspora in the U.K. who are facilitating their travel via Turkey.

In the context of the rise of $\mathrm{Al}$ Qaeda in the Indian Subcontinent (AQIS), the ABT has become more important from a threat perspective. Security experts are of the opinion that $A B T$ is most likely to be a key partner of AQIS. ABT might try to overcome its limited operational capabilities by recruiting members of other groups.

There are also a number of smaller groups that emerged in 2014, inspiring the youth to join jihad both in the country as well as overseas. Currently, all the militant organisations are trying to form a common platform called the 'Bangladesh Jihadi Group'. The group is trying to conduct a spectacular attack to announce their presence. At least 3 members have been arrested. 


\section{Conflict in Syria and Iraq}

The number of fighters who travelled to Syria from Bangladesh has not been definitively established. However, there have been constant efforts to attract Bangladeshi youths by promoting the concept of Islamic State in the society, especially through the social media. Additionally, the involvement of the Bangladeshi diaspora in Syrian conflict remains a concern for Bangladesh. While some youth from Bangladeshi diaspora community in the U.K. have travelled to Syria to fight, a segment of the diaspora has been involved in recruiting Bangladeshis to fight in Syria. On 22 September 2014, Bangladesh police arrested a British citizen of Bangladeshi origin for suspected links with the Islamic State of Iraq and Greater Syria (ISIS) group.

So far, no known militant group has pledged their allegiance to ISIS or its leader Abu Bakar al Baghdadi. However, some members of Jamaatul Mujahideen Bangladesh (JMB) have been actively trying to establish a link with the ISIS. In a video released on 2 August 2014, a group of Bangladeshi individuals declared themselves followers of Abu Bakr al Baghdadi.

There was also a claim about the formation of a new group called Jund AtTawheed Wal Khilafah (Soliders of Monotheism and the Caliphate) in Bangladesh. In a YouTube video uploaded in October, the group announced their launch and in the same video, pledged their allegiance to IS' leader, Abu Bakar Al Baghdadi. In the video, the group appears to be trying to inspire the Bangladeshi Muslims to participate in jihad physically and financially. The group said that it is preparing for what they call "Ghazwatul Hind" or the Final Battle of Hind (Indian subcontinent) to establish an Islamic State. The term Ghazwatul Hind (or Gazwa-e-Hind) is frequently used by self-styled jihadists in Pakistan for getting public support in Pakistan and raising funds to be used in their attacks in Kashmir with the aim of creating what they call Dar-ul-Islam, or the abode of Islam.

\section{Looking Ahead}

With the emergence of AQIS and diffusion of the Islamic State ideology especially through online social media platforms, Bangladesh's militant landscape is changing, which needs constant monitoring. In this crossroads of change, the regrouping of the local militant outfits need to be taken seriously. Bangladesh needs to enhance its capability to detect, monitor, prevent and counter online activities by radical and extremist elements and their impact on the ground. Bangladesh's counter-terrorism has so far relied on operational response, but as the threat spreads, it is necessary to boost the strategic response that emphasise on prevention of radicalisation.

Iftekharul Bashar is an Associate Research Fellow with the International Centre for Political Violence and Terrorism Research (ICPVTR) at the S. Rajaratnam School of International Studies (RSIS), NTU. 


\section{South Asia}

\section{Vikram Rajakumar}

Terrorism, both international and domestic, continued to threaten India's national security. There were six major terrorist attacks in India in 2014; the Chhattisgarh attack on the Central Reserve Police Force, the May and December 2014 attacks in Assam, attacks in Kashmir, the Chennai Railway Station blast in Tamil Nadu and bombings in Burdwan in West Bengal. In 2013, there were only two major attacks, and the continuing situation in Kashmir which were linked to terrorism in the country.

In 2014, 975 deaths were caused by terrorist incidents as opposed to 885 deaths in 2013. The Jammu and Kashmir region saw 193 deaths in 2014 compared to 181 in 2013, and there were 465 deaths in the northeast against 252 in 2013. 314 deaths were attributed to the Maoists (Naxalite or left-wing extremism) in 2014, compared to 421 in 2013, a slight drop in numbers. Compared to 25 in 2013, Islamic extremism caused 3 deaths in 2014.

There were also a number of major breakthroughs by the security forces of India. As many as 77 people have been arrested in connection with their involvement in Islamist terrorist plots and subversive activities. There has also been a visible increase in the level of cross-border cooperation between Indian and Bangladeshi authorities, in terms of intelligence-sharing and other counter-terrorism initiatives.

The main highlights of the year however were the declaration of the formation of Al Qaeda in the Indian Subcontinent (AQIS) by the Ayman Al Zawahiri-led Al Qaeda Central (AQC), and the spread of the influence of the Islamic State of Iraq and Greater Syria (ISIS) in the country. 


\section{Key Incidents}

\section{Chennai Railway Station Blasts}

On 1 May 2014, two low intensity explosions went off inside Chennai's Central Railway Station, killing a 24-year old woman and injuring 14 others. The bombs exploded in two sleeper coaches of the Bangalore-Guwahati Express at $7.30 \mathrm{am}$, about ten minutes after the train arrived at the platform of the Chennai station. Initially, the Indian Mujahideen was believed to have been involved in the blasts as there were similarities between this and other blasts in which the IM has been implicated. However, investigations revealed that a man by the name of Abu Bakar Siddique, chief of the Al Ummah, a proscribed Islamist terrorist group in Tamil Nadu, could have been behind the blasts.

\section{JMB Plot}

On 2 October 2014, an explosion in a two-storey house in the Khagragarh area of Burdwan in West Bengal prevented an imminent terrorist attack by the Jamaat-ul-Mujahideen Bangladesh (JMB). The explosion occurred when two JMB militants set off an improvised explosive device (IED) by accident while assembling it. Both militants died on the spot. Security forces subsequently recovered more than fifty IEDs, a large number of wristwatch dials and SIM cards for mobile phones from the site, which appeared to be a hideout for a JMB cell in India. In addition, micro video cards containing propaganda songs, Taliban training videos, fake Indian identification documents, such as passports and electoral cards, maps of Bangalore and Kolkata, and partially burnt pamphlets and literature written in Arabic and Urdu were confiscated from the site. Investigations revealed that there were plans to detonate some of the IEDs in strategic locations in Kolkata, West Bengal.

\section{Maoist Insurgency}

The Maoist insurgency led by the Communist Party of India - Maoist (CPI-M) continues to be the single biggest domestic security threat faced by India. In the past, Maoists have launched attacks against security forces, public and private infrastructure, as well as civilians. Commonly used tactics include shootings, abductions, vandalism, ambush and attacks using IEDs. The Maoists have also spread across the country, the latest being Kerala state in southern India, more

\section{"CPI-M continues to be the single biggest domestic security threat faced by India."}

specifically, in the Wayanad District. Though the numbers and intensity of the Maoist attacks have been on a decline this year, there were three major attacks targeting security personnel during the year.

The most significant attack took place on 11 March 2014, in the Sukma District of Chhattisgarh state in Central India, when 15 security forces personnel were killed in an ambush by Maoist cadres. One civilian died in the crossfire, while three others were injured. The incident occurred in the Jeeram Ghati area, barely eight kilometres from the location of the infamous 25 May 2013 attack, when CPI-Maoist cadres killed 28 people and injured at least 30 , including members of the state's top leadership belonging to the Congress Party. Earlier, on 28 February 2014, six police personnel, including a Station House Officer (SHO) were killed when a police patrol party headed by the $\mathrm{SHO}$ was enroute to Shyamgiri Hills to patrol a road under construction near Kuwakonda-Bacheli, Dantewada district in the same state. In another major incident on 11 May 2014, seven police commandos were killed in a Maoists landmine blast in the forests of Gadchiroli district of Maharashtra.

\section{Insurgency in the Northeast}

The northeast saw a total number of 465 terrorism related deaths in 2014. A series of violent incidents between the states of Assam and Nagaland, related to a longstanding border dispute, erupted on 12 August 2014, which led to 20 deaths. The scuffle ensued after miscreants from Nagaland fired on agitators outside the Central Reserve Police Force (CRPF) camp in Golaghat district of Assam. Protesters were demanding the release of two students suspected to have been abducted by Naga insurgents. Thereafter, offenders from Nagaland attacked villages and compelled thousands of people to flee, leading to a massive exodus. Over 10,000 people have been displaced from their homes in the two states, now being put up 
in 14 relief camps in Uriamghat in the Golaghat district of Assam.

Following the incidents, the road link between the states of Nagaland and Manipur was cut off due to an economic blockade imposed against Nagaland by various Assam-based organisations including Karbi Students and Youth Council (KSYC), All Dimasa Students' Union (ADSU), All Assam Gurkha Students' Union (AAGSU), Karbi Unemployed Youth Association (KUYA), Karbi Re-Awakening Organisation (KRAO) and United Students Union of Karbi Anglong (USUKA). In December 2014, suspected National Democratic Front of Bodoland (NDFB) rebels killed 63 people in Saralpara village in Kokrajhar district and in Santipur village of Sonitpur district.

Despite the violent incidents of 2014, the insurgency in the seven states that make up India's northeast has been within manageable limits, with a substantial decline of the support base of the militants both internally and in Bangladesh. The region remains however, vulnerable due to poor governance and weaknesses in the internal security apparatus of the states. In addition the geopolitical environment is characterised by volatility, as a result of the shared border between Bangladesh and Myanmar.

\section{Jammu and Kashmir}

This region has seen a drop in the number of militant attacks compared to 2013 , one of the most significant being the killing of eight members of the security forces including one officer and three police men in Uri and Tral on 5 December 2014. However there has been an increase in infiltrations by militants from Pakistan to India through the Line of Control (LoC). This could be attributed to the severe summer flooding in the region. Security forces were busy doubling up as search and rescue personnel, which gave the militants a chance to slip through the borders, although many were later apprehended.

\section{ISIS and AQIS}

The influence of the Islamic State of Iraq and Greater Syria (ISIS) has complicated the already complex web of security threats faced by India. Speeches by Abu Bakr al Baghdadi and videos produced by Al Isabah, ISIS' media wing, have been translated to Urdu, Hindi, and Tamil and circulated through social media sites through
“... the Indian Muslims in South India, particularly Tamil Nadu, have no such clear agenda, although they believe that they have been oppressed for a long time by the Hindu majority."

the Al Isabah Media Production, which is the media unit of "Ansar ut Tawheed Fi Bilad Al Hind" (Supporters of Monotheism in the Land of India) as it claims in its twitter account. Certain ISIS videos and speeches particularly target the Indian Muslims, especially new converts. There are also attempts to persuade non-Muslims to convert.

A region found to be particularly vulnerable to ISIS propaganda is southern India. With the established roots of Islamist militancy in Jammu and Kashmir, northern Muslims have a clear agenda as to why they are fighting. However the Indian Muslims in South India, particularly Tamil Nadu, have no such clear agenda, although they believe that they have been oppressed for a long time by the Hindu majority. This has been leading some members of the community, especially the youth to be influenced by ISIS propaganda. In August 2014, 26 persons were arrested for their demonstrated support to ISIS. It was also reported that a Muslim youth from Tamil Nadu was involved in a suicide attack in Syria at the behest of ISIS.

In May 2014, four youth from Thane, Maharashtra, western India, travelled to Iraq on the pretext of going on a pilgrimage, but broke away from the tour group and travelled to Mosul for joining ISIS and wage Jihad.

On 3 September 2014, AQC leader Ayman Al Zawahiri, announced the establishment of Al Qaeda in the Indian Subcontinent (AQIS), with 
Maulana Asim Umar as its leader. It is believed AQC's move could be to counter the increasing influence of ISIS in the India sub-continent including countries like Afghanistan, Bangladesh, India, Pakistan and Sri Lanka. Intelligence agencies in India believe that Asim Umar may be from the Indian State of Uttar Pradesh, where he attended the Darul Uloom Deoband seminary, before he left India for Pakistan in the late-1990s and joined Harkat ul Juhadi al Islami (HuJI). AQIS has allegedly 'unified' the mujahideen fighting in the region. The significance of AQIS for India is still not clear, though the group claimed responsibility for a couple of attacks in neighbouring Pakistan.

One of the youths is known to have died in an air strike in August 2014, while another was deported to India from Turkey on 29 November 2014. He is currently being interrogated by the National Investigation Agency (NIA) of India. In Jammu and Kashmir, there have been cases of people waving the ISIS flag in the streets of Srinagar on at least three occasions.

On 3 September 2014, AQC leader Ayman AI Zawahiri, announced the establishment of $\mathrm{Al}$ Qaeda in the Indian Subcontinent (AQIS), with Maulana Asim Umar as its leader. It is believed AQC's move could be to counter the increasing influence of ISIS in the India sub-continent including countries like Afghanistan, Bangladesh, India, Pakistan and Sri Lanka.

Intelligence agencies in India believe that Asim Umar may be from the Indian State of Uttar Pradesh, where he attended the Darul Uloom Deoband seminary, before he left India for Pakistan in the late-1990s and joined Harkat ul Juhadi al Islami (HuJI). AQIS has allegedly 'unified' the mujahideen fighting in the region.

The significance of AQIS for India is still not clear, though the group claimed responsibility for a couple of attacks in neighbouring Pakistan.

\section{Counter-terrorism}

Tehseen Akhtar, also known as Monu, who had replaced Yasin Bhatkal (arrested from the IndiaNepal border near Motihari, Bihar on 28 August 2013) as the India operations chief of the IM and who masterminded the attacks on Bodh Gaya (07 July 2013) and a Narendra Modi rally in Patna (27 October 2013) was captured on 25 March 2014 in Naxalbari, in Darjeeling District of West Bengal. Earlier on 22 March 2014, a key
"U.S. and

India however have

agreed to step up joint

combat exercises,

maritime security

endeavours,

intelligence-sharing

mechanisms, and

increase military

exchanges."

IM operative, Zia ur Rehman, a.k.a. Waqas, a citizen of Pakistan, was arrested at the Ajmer Railway Station in the western state of Rajasthan. In a continuing series of arrests, thirteen other IM operatives were also arrested in March 2014.

\section{Looking Ahead}

Terrorist related events, particularly new wave of recruitments of young cadres and attempted attacks in eastern sectors including Kolkata, stemming from Islamic terrorism are likely to increase in India despite the change of government and subsequent overhaul of the security apparatus.

While India currently faces a multi-faceted threat from terrorism and insurgency, the threat from Islamist terrorism is especially high due to the discontent that a segment of the Indian Muslim community has towards the Narendra Modi government. Prime Minister Modi is seen as a Hindu nationalist by many of the Islamic militant groups such as the IM. Thus, even as the overall level of violence could be decreasing, the threat perception remains high.

The counter-terrorism efforts undertaken by New Delhi, although commendable, are still inadequate. Furthermore, the political discordance in relation to the implementation of the National Counter-Terrorism Centre (NCTC) - a nodal agency responsible for tackling all terrorism related cases in the country - 
highlights the absence of timely counter-terrorism interventions by relevant institutions in the country. In addition, there is also a lack of resources (financial, human, and technical) in key counter-terrorism agencies. Investment in terrorism and counter-terrorism research has been woefully inadequate or almost non-existent.

In this context, the visit of the United States President, Barack Obama holds significance. However, so far, the impulse had seemed to be on moving forward a previously signed nuclear deal inked by previous governments, rather than in any specific areas of counter-terrorism cooperation.

U.S. and India however have agreed to step up joint combat exercises, maritime security endeavours, intelligence-sharing mechanisms, and increase military exchanges.

New Delhi must also comprehensively examine the underlying causes of extremism and develop socio-economic policies to address the root causes of conflicts. For example, investments in infrastructure development in the Maoist-affected areas, the Kashmir valley, as well as the northeast region will create employment opportunities, thereby reducing the incentives to join terrorist or insurgent groups. Most importantly, there must be a political consensus against terrorism and for building a more robust counter-terrorism apparatus in the country, specifically one that surmounts local or parochial interests, something that has undermined the professionalism of the security apparatus in India for years.

Vikram Rajakumar is a Senior Analyst with the International Centre for Political Violence and Terrorism Research (ICPVTR) at the S. Rajaratnam School of International Studies (RSIS), NTU. 


\section{South Asia}

\section{Pakistan}

Abdul Basit

As 2014 drew to a close, the Fazlullah-led Pakistani Taliban carried out a massive assault on a school in Peshawar, killing 132 students in cold blood, indicating that Pakistan's fight against home-grown terrorism was far from over. The brazen attack - termed Pakistan's 9/11 — jolted the entire nation, including the country's political and military leadership. During the year, the overall security situation in Pakistan also remained volatile on account of the Afghan Taliban's announcement to continue its armed resistance against foreign troops in Afghanistan, splintering of the Pakistan Taliban, and competition between Al Qaeda Central (AQC) and the Islamic State of Iraq and Greater Syria (ISIS) for influence over local jihadist organisations. The adoption of a first-ever National Internal Security Policy (NISP), the promulgation of the anti-terror Pakistan Protection Act 2014, and the 'Zarb-eAzb' military offensive in the North Waziristan Agency, were highlights of the government's counter-terrorism efforts during the year.

\section{Major Trends in 2014}

\section{U.S. Drawdown from Afghanistan}

At the end of 2014, NATO's International Security Assistance Force (ISAF) completed its 13-year combat mission in Afghanistan. As the year drew to a close, the bulk of NATO/ISAF troops left Afghanistan, leaving behind 13,300 troops - 10,800 from the U.S. and 2,500 from other NATO countries - to pass on the support, assistance, and training mission to the Afghan National Security Forces (ANSFs), also known as the Resolute Support (RS). The agreement to this effect materialised in the form of the Status Forces Agreement (SOFA), which was signed between NATO and the new Afghan government on 30 September 2014. With the 21 November 2014 announcement by the U.S. President Barack Obama to extend the U.S. 
combat mission in Afghanistan for another year, the American troops will also take part in combat operations against the Taliban in Afghanistan.

\section{AQIS-ISIS Competition}

The Islamic State of Iraq and Greater Syria (ISIS) has gained sympathies among the jihadist groups in Pakistan, challenging Al Qaeda's ideological preponderance over these groups. So far, three militant groups Tehrik-e-Khliafat ('Caliphate Movement'), Jandullah ('Soldiers of God'), and the group led by the former Tehrik-eTaliban Pakistan (TTP) central spokesperson Sheikh Maqbool, a.k.a. Shahidullah Shaid, have pledged allegiance to ISIS. In September 2014, ISIS followers also distributed a booklet entitled "Fatah" ("Victory") in Peshawar, Pakistan. The booklet contained twelve articles aiming to recruit volunteers and spread ISIS extremist ideology in Pakistan.

Facing such stiff competition from ISIS, AI Qaeda chief Ayman Al Zawahiri announced the formation of $\mathrm{Al}$ Qaeda in Indian Subcontinent (AQIS), also known as Al Qaeda in South Asia, on 30 September 2014. Faced with a weakening clout, Al Qaeda tried to revive its standing among the jihadist organisations in the region, by shifting its focus to more contentious regional issues like Indian atrocities against Kashmiri Muslims, oppression of Indian Muslims in Gujarat, Assam, and Ahmedabad, and the difficulties of Rohingya Muslims in Burma, among others.

\section{Fragmentation of the Pakistan Taliban}

Even though TTP has never been a coherent entity, comprised of numerous constituent groups from different tribes, the group formally splintered into four major factions in 2014: the Hakimullah Mehsud faction, Waliur Rehman faction, Jamaat-ul-Ahrar ('Group of the Free Ones'), and the Punjabi Taliban. The first round of fragmentation came with the killing of former TTP emir Hakimullah Mehsud in a drone strike in 2013, which sparked a bitter succession struggle among the different TTP constituents. Eventually the head of Swat Taliban Mullah Fazlullah became the TTP chief. The Hakimullah Mehsud and Waliur Rehman constituents of the TTP, who traditionally ruled the group, were not happy with Fazlullah's leadership. In May 2014, the Waliur Rehman left TTP, calling it a criminal and un-
“ Faced with a weakening clout, Al Qaeda tried to revive its standing among the jihadist organisations in the region, by shifting its focus to more contentious regional issues."

Islamic organisation. On 15 September 2014, the Hakimullah Mehsud unit led by Commander Shehryar Mehsud also defected from the TTP, refusing to accept Fazlullah as its head.

The second wave of factionalisation came with the Pakistani government formally starting peace negotiations with TTP, on 29 January 2014. During the peace talks, TTP's central Shura faced fierce opposition from the Mohmand faction of the Pakistani Taliban. The group's leader, Umar Khalid Khurasani, staunchly opposed the peace talks. In April 2014, the group broke away from TTP calling itself Ahrar-ul-Hind ('Indian Freedom Fighters'), and on 26 August renamed itself as Jamaat-ul-Ahrar (JA) ('Group of the Free Ones'). Meanwhile on 3 September, the Punjabi Taliban left TTP and unconditionally accepted the government's peace offer. The faction surrendered to the government, vowing to limit its activities to Afghanistan. The third wave of defections came with the rise of ISIS. Several small constituents of the TTP pledged allegiance to ISIS, the most notable being Tehrik-e-Khlifat ('Caliphate Movement'), Al Tawhid Batallion in Khurasan, and the group led by former TTP spokesperson Shahidullah Shaid.

\section{Volatile Borders}

Pakistan's borders with Afghanistan, India, and Iran remained volatile during 2014. Border tensions between India and Pakistan started in mid-July along the Line of Control (LOC) in the divided Himalayan region of Kashmir and the International Working Boundary (IWB), leading to minor arms and mortar exchanges. After a brief 
lull in mid-October, the situation flared up again along the LOC and IWB. Both sides blamed each other for initiating hostilities. The October 2014 border-tensions were the most serious and worst in more than a decade since the signing of the 2003 ceasefire agreement between the armed forces of the respective countries.

Between Iran and Pakistan, hostilities arose in February 2014 when Iran threatened to send its troops inside Pakistan in pursuit of Pakistanbased Iranian-Sunni militant group Jaish-ul-Adl ('Army of Justice'). On 11 September 2014, Jaish -ul-Adl militants abducted five Iranian Revolutionary Guards from a military check-post in Iran's Sistan-Balochistan province and brought them to Pakistan. In October 2014, border clashes re-erupted when thirty Iranian security personnel crossed the Pakistan border in pursuit of Jaish-ul-Adl militants. Even a high-level meeting between Iranian and Pakistani security officials on 22 October 2014 in Tehran failed to defuse the tensions.

The Afghanistan-Pakistan border (Durand Line) also remained restive throughout 2014. Sporadic cross-border shelling by Pakistani security forces on TTP's sanctuaries in eastern Afghanistan sparked tensions. In August 2014, Sartaj Aziz, Pakistan's National Security and Foreign Affairs Adviser asked Afghanistan's government to hand over the fugitive TTP chief Mullah Fazlullah to Pakistan. In September 2014, Afghanistan's Foreign Minister Zarrar Ahmed Osmani lodged a protest at the $69^{\text {th }}$ meeting of the United National General Assembly (UNGA) over Pakistan's cross -border shelling, terming it "unacceptable." Friction also grew over Pakistan's plan to create a 480-kilometre long trench along the Durand Line, as a measure to stop illegal border crossings and cross-border terrorist attacks. Afghanistan's Senate (Mehrano Jirga) condemned the plan of digging the trench and warned to take the issue to the UN and other international forums. Pakistan has so far dug out 230 kilometres-long despite this.

\section{Anti-Government Protests}

Despite efforts to strengthen the democratic system in Pakistan, the political situation facing Pakistan continued to remain turbulent, with nationwide anti-government protests led by cricketer-turned-politician Imran Khan's Pakistan Tehrik-e-Insaf (PTI) or Justice Party. Imran Khan started his protest movement in August 2014, alleging election fraud during the May 2013
"Following the Taliban attack on Peshawar on 24 December 2014, the Pakistani government announced a 20-point National Action Plan (NAP) to counter religious extremism and terrorism."

general elections. The country-wide protests have not only undermined the government's legitimacy but has also hindered its day-to-day functioning, thus diverting government attention and resources from key security-related issues, especially early repatriation of conflict-hit internally displaced persons and restoration of infrastructure destroyed during the military operation in North Waziristan. The protests have also provided Pakistan's military establishment an upper hand in terms of dictating the country's security and foreign policy, a source for which has directly challenged the authority of Prime Minister Nawaz Sharif.

\section{Pakistan's Counter Terrorism Initiatives in 2014}

\section{National Action Plan to Counterterrorism}

Following the Taliban attack on Peshawar on 24 December 2014, the Pakistani government announced a 20-point National Action Plan (NAP) to counter religious extremism and terrorism. The plan is mostly dependent on the use of kinetic means (constituting a hard approach) to combat terrorism. Among other efforts, the NAP puts emphasis on adding more teeth and girth to Pakistan's current anti-terror laws, creating military courts for expeditious trials of detained terrorists, curbing terrorist financing, banning hate speech, lifting the moratorium on death penalty, as well as intensifying and expanding the on-going military operations in North Waziristan and Khyber tribal regions. Nevertheless, broader political and strategic 
imperatives which form the cornerstone of a successful counter-terrorism strategy seem to be missing.

\section{National Internal Security Policy (NISP)}

On 24 February 2014, the Pakistani government approved Pakistan's first-ever National Internal Security Policy (NISP). The policy addressed the three main aspects of strategic, operational, and day-to-day routine matters. The policy adopts a five-pronged approach to dismantle, contain, and prevent terrorism, and then educate and reintegrate through rehabilitation, those militants who are not hardcore and only involved in petty crimes. The NISP designates the National

National Internal Security Policy (NISP)

On 24 February 2014, the Pakistani government approved Pakistan's first-ever National Internal Security Policy (NISP). The policy addressed three main aspects of strategic, operational, and day-to-day routine matters. The policy adopts a five-pronged approach to dismantle, contain, and prevent terrorism, and to educate and reintegrate through rehabilitation, those militants who are not hardcore and only involved in petty crimes.

The NISP has designated the National Counter Terrorism Authority (NCTA), set up in 2009, as the central body for coordinating and implementing counter-terrorism operations in Pakistan. The NISP has given Pakistan the hitherto missing institutional structure required to manage the competing demands of the different security and law enforcement agencies.

\section{Pakistan Protection Act 2014}

In July 2014, Pakistan's National Assembly passed the Pakistan Protection Bill, providing Pakistani security forces with additional powers to fight terrorism. The Bill adopts a 'guilty-untilproven-innocent' approach, placing the burden of proof on the accused. Furthermore, Pakistani security forces are given vested authority to shoot at sight, to arrest suspects, and to search houses without search warrants. The bill has been enacted as a special set of security measures for two years, following which, its status would be re-evaluated.

\section{North Waziristan Offensive (Operation Zarb-e- Azb)}

On 15 June 2014, the Pakistan Army launched a much awaited and major military offensive Zarb-

\section{"The challenge of radicalisation and extremism continue to hinder Pakistan's counter-terrorism campaign."}

e-Azb (named after the sword of the Holy Prophet Muhammad) against local and foreign militants in FATA's North Waziristan Agency. The operation was launched in response to the attack on Karachi International Airport on 8 June 2014 by the TTP, and the failure of the TTPgovernment peace talks.

The Pakistan Army claims to have killed about 1,100 militants since the launch of the operation, clearing 80 percent of North Waziristan's territory from the jihadist presence, including the destroying of the militants' command and control structure and facilities that manufacture improvised explosive devices (IEDs). The Zarb-e -Azb operation is to continue until the whole area is cleared of militants.

\section{Looking Ahead}

The challenge of radicalisation and extremism continue to hinder Pakistan's counter-terrorism campaign. In the absence of meaningful madrassa reforms and curriculum revision, the radical madrassas continue to churn out individuals susceptible to militant recruitment. Such madrassa networks have been used by terrorists as lodging and shelter points while conducting terrorist attacks in Pakistan's main cities.

\section{Defunct National Counterterrorism Authority}

Pakistan's National Counter Terrorism Authority (NCTA) remains defunct, due to executive lethargy, as bureaucratic turf wars have crippled its day-to-day functioning. Fighting and winning against terrorism is as much about the right leadership as it is about the right strategy.

Thus far, the Joint Intelligence Directorate (JID), an NCTA subsidiary, intended to be responsible for the oversight of the operational aspects of 
intelligence sharing and inter-agency cooperation among the country's 26 intelligence agencies, has not been formed. Overcoming its own bureaucracy and bringing operational unity to the country's many intelligence and security agencies through a cohesive national level anti-terrorism policy remains the foremost challenge for the NCTA.

\section{Backlash of North Waziristan Offensive}

Moving beyond operation Zarb-e-Azb, the fight against the terrorists will be in mainland Pakistan. TTP has shown a strong presence and outreach in Pakistan's major cities. Managing the backlash through intelligence-led smart policing will be the only way to overcome this challenge. The militants escaping from North Waziristan have taken a tactical retreat in Afghanistan's Khost and Pakitika provinces, where they are setting up their new sanctuaries to fight another day.

With the approaching winter, the militants will go into hibernation and try to reenter North Waziristan in the summer (from May till June 2015). Thus, the Zarb-e-Azb offensive can only be deemed fully successful if it can effectively minimise the post-operation retaliation and block re-entry of terrorists.

\section{Conflict-affected Regions and IDPs}

Reconstructing the destroyed infrastructure in North Waziristan and rehabilitation of internally displaced persons (IDPs) is as significant as dislodging militants and destroying their infrastructure in the long-term.

Indeed, military offensives are just one part of counter-terrorism, which will need to be supplemented by political and socio-economic measures. In the past, military operations in Swat in April 2009, and in South Waziristan in July 2009, were successful from a kinetic perspective, but the less-than-impressive and slow-paced reconstruction programs almost reversed the gains. Hopefully, the same will not be the case with the military operations in North Waziristan. At the same time, it is important to understand the significance of the TTP offensive against the school children in Peshawar in December 2014. While the families affected by the incident particularly, as well as the government and the country as a whole, comes to grips with the incident, its broader geo-political implications need to be understood.

What prompted this carnage? It may be far too simplistic to blame the U.S. or the Indian intelligence agencies, or even the international community (for awarding the Nobel Peace Prize to Malala Yousafzai, herself a victim of the TTP atrocities for advocating education for women in Pakistan) for the massacre.

Pakistan needs to understand where it stands and what it needs to do to rein in the terrorists, along with the extremist ideology on its own soil. The U.S. drawdown from Afghanistan in 2014 also places Pakistan at a crossroads in its history. It is both a challenge and an opportunity. Pakistan can either be an agent of peace in the region, or an obstruction by continuing its support for militant groups perceived as favourable to its own national interest and remaining enmeshed in proxy wars with its neighbours.

Abdul Basit is an Associate Research Fellow with the International Centre for Political Violence and Terrorism Research (ICPVTR) at the S. Rajaratnam School of International Studies (RSIS), NTU. 


\section{South Asia}

\section{Sri Lanka}

\section{Iromi Dharmawardhane}

Although militarily defeated, an international network of the Liberation Tigers of Tamil Eelam (LTTE) remains intact, as evident from at least half a dozen foiled attempts to carry out terrorist attacks in Sri Lanka since the war ended in 2009. Much of the conflict-affected Tamil community in Sri Lanka also remains under the grip of the LTTE's separatist ideology. At the same time, despite the many large-scale reconstruction projects and high economic growth rates, food insecurity and high unemployment have undermined the government's efforts to engage and gain the confidence of the Tamil community in the conflict-affected areas in the country. Islamist extremism has also taken root in Sri Lanka, with groups like Thowheed Jamath provoking religious discord. Concurrently, Sinhalese groups like the Bodu Bala Sena continue to demonise Muslims in the country.

\section{LTTE Reviving?}

On 13 March 2014, Kajeeban Ponniah Selvanayagam, a.k.a. Gopi / Gobi, a.k.a. Kasiyan, shot and wounded a police officer who was attempting to arrest him for involvement in subversive activities against the state. The incident occurred in Kilinochchi, the LTTE's former strong-hold, in the Northern Province of Sri Lanka. Subsequent investigations revealed that Gopi was in fact a former bodyguard of the LTTE's slain leader Velupillai Prabhakaran and the leader of a newly formed LTTE cell, planning the assassination of the Sri Lankan President, Mahinda Rajapaksa and/or the Secretary of Defence, Gotabaya Rajapaksa. Gopi and his associates had setup four LTTE units in the north and one in Colombo.

Many former LTTE cadres or their family members were involved in the operation, while unemployed youth were also targeted in establishing a network in Sri Lanka. Investigations also led to the recovery of arms, 
ammunition, and explosives, including 56,000 rounds of Magnum pistol ammunition, 120,000 rounds of $9 \mathrm{~mm}$ bullets, and 2,750 of 12-bore shotgun cartridges - packed with grease so that it may be used for a period of ten years or more.

On 11 April 2014, Gopi and his two main associates, Sunderalingam Kajeepan, a.k.a. Thevian and Navaratnam Navaneethan, a.k.a. Appan, also senior members of the LTTE, were killed during an armed encounter with the security forces in the jungles of Welioya, in northern Sri Lanka.

\section{Cracking down on the LTTE's International Network}

At present, the Terrorist Investigations Department (TID) of the Sri Lankan police has in its custody about 100 suspected LTTE activists, approximately half of whom were arrested after the foiled plot in March-April 2014. According to the government, recent attempts to revive the LTTE in Sri Lanka was funded and supported by the LTTE's front organisations based overseas. The LTTE's international network is known to operate through front or cover organisations in over 50 countries.

In March 2014, the Sri Lankan government designated the LTTE and 15 front organisations and 424 individuals based overseas as "foreign terrorist" entities under the United Nations Security Council Resolution 1373 (2001) for supporting terrorism. Among the designated entities were: the Norway based Tamil Coordinating Committee (TCC) or Nediyavan Group (also known as the Castro Group), led by Perinbanayagam Sivaparan, a.k.a. Nediyavan, based in Norway; the Global Tamil Forum (GTF) led by (Fr.) Joe Emmanuel, based in the United Kingdom; the Transnational Government of Tamil Eelam (TGTE) led by Visvanathan Rudrakumaran and operating in the US and Canada; and the France-based Headquarters Group led by Segarampillai Vinayagamoorthy, a.k.a. Vinayagam. Accordingly, having contact with and moving the assets of these groups are now prohibited. The government also requested concerned foreign governments to investigate the activities of the listed entities.

Colombo also obtained more than 40 INTERPOL 'Red Notices' for the arrest of suspected LTTE members operating abroad in 2014. In March 2014, Subramaniam Kapilan, a.k.a. Nanthagopan, was arrested in cooperation with
“ Terrorist Investigations Department (TID) of the Sri Lankan police has in its custody about 100 suspected LTTE
activists."

Iranian and Malaysian authorities. Nanthagopan was a key advisor to the international network, operating in Southeast Asia, as well as a deputy leader of the Nediyavan Group. Together, Colombo and Kuala Lumpur also dismantled the LTTE network in Malaysia, leading to the deportation of at least seven senior LTTE members from Malaysia to Sri Lanka in 2014.

\section{Islamic Extremism and Terrorist Cells}

In recent years following the end of the war in 2009, Islamic religious organisations like Thowheed Jamath - Wahhabist groups which preach religious extremism and intolerance have taken root in the underdeveloped Eastern Province, and have gradually gained influence in other parts of Sri Lanka. One of the main objectives of the Thowheed Jamath movement is the implementation of Sharia law for Muslims in the country. It also advocates, for example, compulsory wearing of the burka for Muslim women - a practice foreign to Sri Lanka. It is estimated that at present 10 percent of Sri Lankan Muslims adhere to the ideology of Thowheed Jamath. The activities of the extremist movement have included the construction of mosques and madrassas in different parts of the country, which has created communal discord, while it has also been inciting religious intolerance. The emergence of such a movement is strongly opposed by groups like the Bodu Bala Sena (BBS), meaning or 'Buddhist Power Brigade,' which also preaches extremism against the Muslim community, and has caused significant communal tensions in Sri Lanka.

Groups like Al Qaeda Central, Lashkar-e-Taiba, and other jihadist elements have also been active in the country. This was evident from the plot to attack the US consulate in Chennai and 
Israeli consulate in Bengaluru in Southern India, involving two Sri Lankan Muslims: Mohammed Zakir (Sakir) Hussain and Mohammad Hussain Mohammad Sulaiman, both of whom had conducted reconnaissance for the planned attacks. Another Sri Lankan Muslim, Mohammed Salim, as well as two Tamils of Sri Lankan origin - Sivabalan and Arun Selvarajan - were subsequently arrested and charged in India for their involvement in the plot. The Sri Lankan government has expressed concern over the increasing presence of overseas Islamist terrorist cells in the country. In an article published in the U.S. Defence Department's journal Prism in August 2014, former Sri Lankan Defence Secretary Gotabaya Rajapaksa observed that, "Some Islamic groups in Sri Lanka have started to establish ties with LTTE-linked agents to create further problems."

\section{Sinhalese Backlash}

On 12 June 2014, three Muslims assaulted a Buddhist monk in the Kalutara District of southwestern Sri Lanka, and the three were subsequently arrested. Later, on 15 June 2014, stones were thrown at the monk by several other Muslims as he was walking past a mosque in Dharga Town in the Kalutara District. These incidents, reportedly combined with the effects of a provocative speech made in the district on 15 June 2014 by the extremist Buddhist monk Galagoda Aththe Gnanasara Thera, the leader of BBS, triggered attacks by Sinhalese. SinhalaBuddhist mobs targeted shops and residences of Muslims in the coastal towns of Dharga Town, Aluthgama, and Beruwala in the Kalutara District during 15 and 17 June 2014. In the attacks, four Muslims died, and over 60 individuals, including journalists, police personnel, and pedestrians, were seriously injured. At least 82 shops and 211 houses were destroyed or damaged during the three days of violence. The Sri Lankan government and police were heavily criticised for their failure to stop the violence, although a curfew was imposed on 16 June when the violence was at its peak, and about 10,000 police and Special Task Force (STF) personnel and an Army mobile team were deployed to the areas under attack. The former Sri Lankan President Mahinda Rajapaksa also reaffirmed the right to religious freedom in the country and the government launched a special program supported by district authorities to bring the situation to normalcy.

\section{"Colombo continues to make progress in the implementation of recommendations for post-conflict national reconciliation..."}

\section{National Reconciliation}

Colombo continues to make progress in the implementation of recommendations for postconflict national reconciliation made by the Lessons Learnt and Reconciliation Commission (LLRC) under a National Plan of Action. In this respect, many military bases were also withdrawn from the conflict-affected areas in the north and the east in 2014, while those in strategic locations have been retained due to security concerns. About 19,500 acres of land, out of the approximately 26,000 acres occupied by the military in these areas since 2009 , have now been returned to civilian owners. Demining efforts in conflict-affected regions have been speedy and successful. In 2014, 55,761 mines and unexploded ordnance (UXO) were recovered and neutralised.

In 2014, the government spent approximately Rs. 300 million (US \$2.28 million) for livelihood relief for conflict-affected populations and Rs. 10 billion (US \$ 7.61 million) to develop local government institutions in the Northern and Eastern Provinces in 2014. In October 2014, the iconic Yal Devi Express train resumed its run from Colombo to Jaffna after 24 years, connecting the populations across Sri Lanka as well as the economies of the conflict-affected regions with the national economy. In November 2014, Sri Lanka began construction work on a four-lane highway to the north from Colombo to Jaffna.

A part of the Atchchuvely Industrial Estate opened in Jaffna in August 2014, and is expected to provide direct and indirect employment to about 10,000 people in the region. 
Nevertheless, more programs to reduce the economic vulnerabilities of the conflict-affected populations are direly needed, as the regions have been suffering from food insecurity and high unemployment since the end of the war in 2009. As noted by the Sri Lankan government, lack of job opportunities and the rising cost of living are forcing many children in the north to drop out from lower-secondary school $\left(6^{\text {th }}\right.$ to $8^{\text {th }}$ grade $)$ to support their families.

In April 2014, a new police unit at the national level was formed to address complaints related to communal tensions, unauthorised construction of religious places, unethical conversions, and other related issues. In response to the Sinhalese mob attacks on the Muslim communities in the south which were likely inspired by the BBS, the government prohibited participation in rallies that would encourage ethnic or religious hatred. In December 2014, National News Agency Ltd., Sri Lanka's first Muslim-owned mass media outlet, was launched under the auspices of the government. However, the Sri Lankan Muslim population in general remains deeply shaken by the attacks and hostility by the segment of Sinhalese extremists. As noted by the Sri Lankan government, lack of job opportunities and the rising cost of living are forcing many children in the north to drop out from lower-secondary school $\left(6^{\text {th }}\right.$ to $8^{\text {th }}$ grade) to support their families.

In April 2014, a new police unit at the national level was formed to address complaints related to communal tensions, unauthorised construction of religious places, unethical conversions, and other related issues. In response to the Sinhalese mob attacks on the Muslim communities in the south which were likely inspired by the BBS, the government prohibited participation in rallies that would encourage ethnic or religious hatred. In December 2014, National News Agency Ltd., Sri Lanka's first Muslim-owned mass media outlet, was launched under the auspices of the government. However, the Sri Lankan Muslim population in general remains deeply shaken by the attacks and hostility by the segment of Sinhalese extremists.

\section{Looking Ahead}

While the Sri Lankan government faces such formidable challenges in achieving national reconciliation, the greatest threat remains the activities of the LTTE's surviving international network, especially its relentless misinformation campaign. The government must adopt a strategic, coherent, and long-term communication strategy to counteract the LTTE's decades-long propaganda war effort to engage the international community and Tamil diasporas. The Sri Lankan government, in conjunction with the private and non-profit sectors, needs also to reach out more conscientiously to the conflict -affected Tamil population so that their economic, social, psychological, and political needs are met, as well as introduce counter-ideology measures. At the same time, the government must criminalise all acts related to the spread of extremism and prejudice in the country, so that communal relations can be restored between the Buddhists and Muslims.

Iromi Dharmawardhane is a Senior Analyst with the International Centre for Political Violence and Terrorism Research (ICPVTR) at the S. Rajaratnam School of International Studies (RSIS), NTU. 


\section{Central Asia}

\section{Kazakhstan, Kyrgyzstan, Tajikistan, Turkmenistan, and Uzbekistan}

\section{Central Asia}

Countries in Central Asia - Kazakhstan, Kyrgyzstan, Tajikistan, Turkmenistan, and Uzbekistan - have two main concerns. The first is the withdrawal of the U.S.-led international forces from neighboring Afghanistan. Though the organisational and operational capabilities of Central Asian groups such as the Islamic Movement of Uzbekistan (IMU), Islamic Jihad Union (IJU), Jund al-Khilafah (JaK) and Jamaat Ansarullah (JA) have been significantly degraded, there is a general perception that the drawdown of the U.S. troops from Afghanistan could re-empower these entities. The second is the increasing number of Central Asians travelling to Syria and Iraq to fight along with the Islamic State of Iraq and Greater Syria, (ISIS) and other jihadist groups and the possibility of these battle-hardened militants carrying out attacks upon return to their home countries. At present, an estimated 1,000 Central Asian militants are in Syria and Iraq. In addition, Central Asians studying and living in Turkey, the Middle Eastern countries and in Russia are being recruited by the jihadist groups. Some of these experienced and battlehardened militants have returned to their respective home countries and were found to be engaged in terrorist activities. 


\section{KAZAKHSTAN}

Currently, Kazakh citizens form the bulk of the Central Asians fighting in Syria and Iraq. In 2014, Kazakhstan's National Security Committee (NSC) stated that more than 300 Kazakh nationals, half of which were women, have been fighting with ISIS in Syria and Iraq. The increasing involvement of Kazakhs fighting in Syria and Iraq has been due to the the spread of radical ideologies, especially among the youth in Kazakhstan - particularly in Atyrau, Aktobe, South Kazakhstan, and Jambyl provinces.

Furthermore, Tablighi Jamaat and Hizb ut-Tahrir al-Islami (HTI, the Islamic Liberation Party) have been relentlessly trying to recruit the youth. HTI has been active in Kazakhstan's Jambul and Almaty provinces and working with its cells in neighbouring Central Asian republics. It also has increased its activities in western Kazakhstan due to spread of Salafi and Wahhabi ideologies in neighbouring Russian republics of Tatarstan and Bashkortostan.

On 30 June 2014, a court in Almaty sentenced five members of $\mathrm{HTI}$ to six to seven and a half years in prison on charges of "inciting ethnic or religious hatred, advocating the overthrow of constitutional order by force, and propagating terrorism."

\section{Kazakh Fighters in Syria and Iraq}

In January 2014, Kazakh security forces arrested Kamil A. Abdulin who took part in the Syrian war. According to Kazakh authorities, Abdulin, his wife and young daughter moved through Georgia and Turkey to Aleppo in Syria. Under the nom de guerre of "Abuzar," Abdulin joined a squad of Kazakh and Central Asian militants named "Old Turkestan Jamaat" which was led by Amir Omar. Old Turkestan Jamaat is believed to be one of the Al Qaeda cells in Syria.

On 22 November 2014, ISIS released video titled "Race towards Good" featuring Kazakh nationals, including about 20 children, being trained at a training camp. The camp appears to be situated in the Syrian city of Raqqa, a stronghold of ISIS.

Kazakh militants trained in Syria also have been engaged in terrorist activities abroad. On 9 January 2014, Kyrgyzstan's security services arrested two Kazakh nationals in the Kyrgyz provinces of Bishkek and Chuy. The two men

\section{“...Tablighi Jamaat and Hizb ut-Tahrir al-Islami (HTI, the Islamic Liberation Party) have been relentlessly trying to recruit the youth."}

reportedly completed their military training in Syria and travelled to Kyrgyzstan to establish a cell and recruit the Kyrgyz citizens to fight in Syria. The police seized a cache of arms assault rifles, pistols, and ammunition at the time of the arrest.

\section{Government Response}

In 2014, the Kazakhstan government scaled up its response against terrorism and extremism. Dozens of terrorist and extremist personalities have been arrested and a number of terrorist plots were disrupted. On 3 February 2014, a court in Kazakhstan tried four Kazakh nationals for their involvement in militant activities in Syria.

They were arrested by the Turkish security agencies in October 2013 while slipping into Turkey from Syria, and were extradited to Kazakhstan. The four men were reportedly planning to move their families from Kazakhstan to Syria.

On 29 April 2014, a court in Kazakhstan sentenced E. Esembaev, a resident of Pavlodar region, to six years on the charges of "incitement of religious hatred and propaganda of terrorism and extremism." Esembaev studied at a university in Syria. After returning home in 2011, he started to propagate his radical views in different towns in Pavlodar region, urging people to travel to Syria to take part in in the fight.

A number of non-governmental organisations (NGOs) have been counselling students in schools and universities with a view to immunise the youth against extremism. 
The Kazakh media has also stepped up its efforts to educate and inform the public on the dangers of extremism, by broadcasting interviews with former militants who publicly acknowledge that they regret their deeds, while appealing to Muslims in Kazakhstan not to be induced by propaganda of ISIS or other groups. For instance, in a media interview, Kamil A. Abdulin, who returned home from Syria, explained that he decided to leave the war after he witnessed immoral dealings involving "the families and friends of his armed compatriots who died during the war."

\section{KYRGYZSTAN}

Although there were no terrorist attacks in Kyrgyzstan in 2014, the threat from militant groups such as the Islamic Movement of Uzbekistan (IMU), Islamic Jihad Union (IJU) and Jaish al-Makhdi (JM) persists in the country. IMU and IJU in Kyrgyzstan and Tajikistan have been recruiting the locals to join the fight in Syria and Iraq. On 24 February 2014, Kyrgyzstan's State Committee for National Security (SCNS) detained a member of the IMU - a Kyrgyz national - at the Osh international airport where he arrived from Russia. The detainee underwent military training in Federally Administered Tribal Areas (FATA) of Pakistan and in Syria. He reportedly moved from Syria to Turkey where he was engaged in recruiting Kyrgyz citizens to join the rebel forces in the fight against the Syrian regime. The Kyrgyz nationals fighting in Syria and Iraq with hard line radical militants is estimated to be between 200 and 300 .

\section{HTI}

Hizb ut-Tahrir al-Islami (HTI) has extensive networks, both in the north and south of Kyrgyzstan. Its branch in the southern Kyrgyz province of Osh is reportedly in charge of the Central Asian region.

The group is mainly active in Talas and Chuy provinces in northern Kyrgyzstan and in Osh andJalalabad provinces in southern Kyrgyzstan, with an estimated 10,000 members across the country. HTI is actively conducting online indoctrination campaigns to widen its support base with websites in the Uzbek, Russian and Kyrgyz languages.
66

Although there were no terrorist attacks in

Kyrgyzstan in 2014, the threat from militant groups such as the Islamic Movement of Uzbekistan (IMU), Islamic Jihad Union (IJU) and Jaish al-Makhdi (JM) persists in the country."

\section{Kyrgyz Fighters in Syria and Iraq}

On 8 January 2014, a Kyrgyz member of the IJU, who had been recruiting locals to fight in Syria, was arrested by the Kyrgyz police in Jalal-Abad. After receiving military training at a terrorist camp in Afghanistan, he reportedly returned home to plot a series of terrorist attacks in Jalal-Abad.

The IJU have also recruited youth from the JalalAbad and Kyzyl-Kiya provinces to fight in Syria alongside Islamist opposition forces. On 17 February 2014, police in Kyrgyzstan arrested six Kyrgyz nationals some of whom reportedly trained at rebel camps in Syria. The six men were plotting terrorist attacks in the Kyrgyz cities of Bishkek and Osh.

In December 2014, the Salah al-Din provincial division of the ISIS in Iraq released a video claiming a suicide bombing by Abu Abdullah- a Kyrgyz fighter - at the headquarters of the National Police of Iraq in southeast of Samarra. Abu Abdullah detonated a four-wheel-drive truck with 1.5 tonnes of explosives at the target, killing and injuring dozens.

In July 2014, Kyrgyzstan's Ministry of Internal Affairs reported a worrying increase in the number of Kyrgyz women involved in terrorist and extremist activities from 1.1 percent in 2005 to 23 percent in 2014. In July 2014, at least ten of 80 Kyrgyz nationals involved in the war in Syria were reported to be women, mostly 
recruited from Turkey and sent across the border into Syria. By end December 2014, the number of Kyrgyz national fighting in Syria and Iraq has risen to nearly 300 .

\section{Government Response}

Over the past few years, Kyrgyzstan has arrested dozens of $\mathrm{HTI}$ members and seized many extremist propaganda materials. On 23 June 2014, Bishkek City Police Department dismantled the HTI's cell in Bishkek and arrested its five members. The detainees were residents of Norin, Jalal-Abad and Talas provinces of Kyrgyzstan. The police also seized a large number of extremist literature including brochures, leaflets, notes and CDs during the raid.

On 24 March 2014, Kyrgyzstan's State Committee for National Security (SCNS) and provincial Police Department detained the leader of the HTI's women wing, a 35-year-old resident of Tokmok city. Since January 2014, about 145 women have been arrested. Kyrgyzstan has also been clamping down on jihadist activities in the Internet, blocking websites with extremist content.

\section{TAJIKISTAN}

The security of Tajikistan remains fragile with concerns of more instability after the withdrawal of US troops from Afghanistan particularly with threats from Islamic Movement of Uzbekistan (IMU) and Jamaat Ansarullah (JA).

Meanwhile, nearly 300 Tajik nationals are reported to have fought with jihadists in Syria and Iraq. A principal security concern for the government of Tajikistan is the threat of battlehardened Tajik militants returning home to mount attacks.

\section{Tajik Militants in Syria and Iraq}

On 22 January 2014, the Tajik media reported that Ahmad - a 9-year-old Tajik boy participated in the fighting in Syria. Fluent in Tajik, Turkish, Arabic and Russian languages, Ahmad is reported to be acting as an interpreter for militants from Chechnya (Russia), Turkey and other countries.

\section{“In August 2014... a Tajik citizen was arrested in Osh, Kyrgyzstan, from where he was attempting to travel to Palestine to join the "jihad" against Israel."}

In August 2014, ISIS appointed a Tajik man as "Emir" of the northern Syrian province of Raqqa. A few days later, a Tajik citizen was arrested in Osh, Kyrgyzstan, from where he was attempting to travel to Palestine to join the "jihad" against Israel. Many fighters are being recruited from among the Tajik Diaspora in Russia.

On 12 November 2014, Tajik police detained 12 members of JA who have recruited residents of the northern Tajik province of Sughd to fight in Syria. JA, the Islamic Movement of Uzbekistan (IMU)'s branch in Tajikistan is also supported by Al Qaeda. It aims to establish a Sharia-based governance in Tajikistan.

The emir of the group is Amriddin Tabarov (also known as Mullo or Domullo Amriddin) with close ties to the Afghan Taliban leader Mullah Omar and he was a candidate for Al Qaeda's top post after Osama bin Laden's death. Although not a sophisticated and strong terrorist outfit, JA was responsible for several bloody incidents in Tajikistan, using various tactics including a suicide bombing, ambush and grenade attacks.

In September 2014, Tajikistan's security agencies arrested 11 members of the IMU in Sughd. Two of the arrested were reported to have fought in Syria. 


\section{Drug Trafficking}

Tajikistan's porous borders are being used by drug smugglers as a transit point for the transportation of Afghan heroin to Russia and Eastern Europe. According to the UN Office on Drugs and Crime (UNODC), about 90 tonnes (or 30 percent) of heroin produced in Afghanistan annually is smuggled through "northern routes" in Central Asia, out of which 75-80 tonnes passes through 1.5 thousand kilometres of porous TajikAfghan border. The illegal transit of Afghan narcotics has been a vital source of funding for terrorist activity in the region.

\section{Government Response}

On 24 September 2014, the Collective Security Treaty Organisation (CSTO), composed of Armenia, Belarus, Kazakhstan, Kyrgyzstan, Tajikistan, and Russia, held its annual summit in Sochi, Russia. The member-states discussed the security situation in Afghanistan and highlighted that border security will be one of the major concerns for the Organisation. In the aftermath of the summit, CSTO decided to increase its military aid to Tajikistan to boost security on its borders with Afghanistan. Earlier in October 2013, the Tajik Parliament had ratified an agreement with Moscow to extend Russia's military presence in Tajikistan until 2042.

\section{TURKMENISTAN}

Turkmenistan's security concerns, like other countries, are founded on the U.S. forces drawdown in Afghanistan. This is exacerbated by Taliban's growing presence in northern Afghanistan since April 2013, and its attacks on the Turkmen border guards since February 2014.

\section{Key Challenges}

The porous and ill-protected borders between Turkmenistan and Afghanistan have been most vulnerable to possible terrorist infiltration into Central Asia. In 2014, Taliban militants attacked Turkmen border guards at least three times.

On 26 February 2014, three Turkmen border guards were killed by the Afghan Taliban militants crossing the border from Afghanistan's north-western Badghis province into Turkmenistan. It was the first attack reported

\section{"The porous and ill- protected borders between Turkmenistan and Afghanistan have been most vulnerable to terrorist infiltration into Central Asia. In 2014, Taliban militants attacked Turkmen border guards at least three times."}

against the Turkmen border guards on the Afghanistan-Turkmenistan border since 2001. However, the Taliban denied its involvement in the incident with its spokesman, Qari Yousuf Ahmadi stating that Badghis officials were "looking to achieve their malicious objective by blaming the attack on the Taliban." Ahmadi contended that the Taliban seeks "good relations with Afghanistan's neighbors and the international community based on mutual respect and did not interfere in internal affairs of others and expect the same from others."

Tensions on the border were heightened when Taliban militants killed at least three Turkmen border guards during a cross-border attack from Ghormach District, northern Afghan province of Faryab on 24 May 2014. On 8 September 2014, Taliban militants attacked border posts of Turkmenistan however without any casualties.

It is believed that attacks on the Turkmen borders have been attempts by the Taliban to establish a passage to Central Asia. There is also an alternate perspective that Taliban's target is not Turkmenistan or Central Asia; the attacks were likely aimed at heightening tensions in the north and west of Afghanistan which used to be relatively trouble-free. 
Turkmenistan is also one of the main transit routes for the transportation of Afghan drugs to Russia and Europe. Drugs through Turkmenistan also go across Iran and the Caspian Sea to the Caucasus, Turkey and the Balkans. It is believed that about 80 tonnes of drugs are transported annually through Turkmenistan.

\section{Government Response}

Turkmenistan has made efforts to boost security along its border with Afghanistan, mainly to counter the Taliban offensive and narcotics trafficking. It has mobilised its army reservists and contract service personnel and deployed them to the border with Afghanistan. In March 2014, ethnic Turkmens residing in northern Afghanistan also took up arms to protect the border and to prevent attacks by the Taliban.

\section{UZBEKISTAN}

Uzbekistan is also a victim of the spillover effects arising from the armed conflicts in Syria and Iraq. About 50 Uzbek nationals are believed to have fought in Syria, although it is difficult to put an exact number. Moreover, Uzbekistan now needs to mitigate the impact of the U.S. drawdown in Afghanistan.

Central Asians fighting in Syria and Iraq are predominantly ethnic Uzbeks. However, most of them are believed to be Uzbeks from a number of countries and not necessarily only from Uzbekistan. There are substantial Uzbek minorities in a number of countries i.e., Afghanistan - 2.9 million, Tajikistan - 1.1 million, Kyrgyzstan - 680,000, Kazakhstan 500,000 , and Turkmenistan - nearly 350,000.

On 28 August 2014, a group of unknown people hung the black flag with Arabic scripts, similar to the ISIS' flag, on a bridge in Tashkent. It was the first-ever open demonstration of support for ISIS in the country. In September 2014, in a statement sent to the news agency, an Uzbek jihadist named Bekobadiy claimed that ISIS appointed an "emir" for Uzbekistan. However, he did not disclose the name.

Ethnic Uzbeks have set up at least three jamaats (units) in Syria for the fight. These units have been fighting either with the Chechen-led Jaish al -Muhajireen wal-Ansar (Army of Emigrants and Helpers, or the JMA), the ISIS, the AI Qaedaaffiliated al-Nusra Front or Ahrar ash-Sham
"Ethnic Uzbeks have set up at least three jamaats (units) in Syria... either with the Chechen-led Jaish al-Muhajireen walAnsar (Army of Emigrants and Helpers, or the JMA) the ISIS, the Al Qaeda-affiliated alNusra Front or Ahrar ash -Sham against the Syrian and Iraqi governments."

against the Syrian and Iraqi governments. One of the jammats - Kateebat Imaam Al-Bukhari (KIB, Imam Bukhari Battalion), which is also known as Imam Bukhari Jamaat or Mawarannahr Mujahideen in Syria, was founded by the Uzbek fighters as an independent jihadist unit in Syria in October 2013. KIB appears to be most prominent among other Central Asian militant units in Syria and Iraq. Sheikh Muhammad Ali Al-Uzbeki was said to be the commander of the unit. KIB is operating particularly in Syria's northern Aleppo and northwestern Latakia provinces. The videos released by KIB in recent months suggest that it aims "is to topple the regime of Bashar al-Assad through waging armed "jihad" against progovernment forces in Syria and establish Shariabased rule there and ultimately in "Mawaraunnahr" (historical name for Central Asia), particularly in Uzbekistan, Kyrgyzstan and Tajikistan. KIB is running its own website www.albuxoriy.com in Uzbek language. It also created its own media wing - 'Al-Fath Studio.' The unit has been fighting under the coordination of JMA, al-Nusrah Front, ISIS and Ahrar ashSham. Sabri's Jamaat is another Uzbek unit operating under ISIS. The group also comprised many fighters from Russia's Dagestan Republic. In January 2014, Sabri Jamaat's media wing posted a video explaining that the jamaat was named after its leader, Sabri. The unit is currently 
led by Khalid ad-Dagestani, a jihadist from Dagestan, after its previous emir, Abdullah atToshkandi from Uzbekistan was killed in January 2014. In March 2014, the jamaat declared allegiance to the ISIS and to the leader of the JMA, Abu Omar al-Chechen (also known as Abu Omar al-Shishani).

The other Uzbek Unit is Seyfuddin Uzbek Jamaat is another Uzbek unit which is reported to have fought under al Nusrah Front. The group is led by Abu Hussein. Some reports suggest that the Seyfuddin Uzbek Jamaat is receiving support from the Islamic Movement of Uzbekistan (IMU).

\section{IMU}

In May and June 2014, IMU suffered significant losses by Pakistani air force operations in FATA. At present, several IMU militants are operating independently in different parts of FATA and most likely in Northern Afghanistan as well. The group's limited activities in Central Asia would indicate its lack of resources and restricted operational capability. In September 2014, the IMU's leader, Usmon Ghazi, declared allegiance to the ISIS in an effort to attract fresh recruits and reclaim popular support in Central Asia.

At the same time, with the ideological and logistical support of Al Qaeda, IMU managed to recruit several Turkish and German citizens. Mounir and Yassin Chouka, German citizens of Moroccan origin who are senior members of the IMU, produced several propaganda videos encouraging German Muslims to move to Pakistan to join the jihad there. On 6 February 2014, the Munich State Court charged a 27-yearold German national for his involvement in terrorist activities in Germany. The defendant reportedly had made an attempt to recruit members for the IMU.

\section{IJU}

The Islamic Jihad Union (IJU) has also been active in 2014, and has urged its followers in Central Asia and Russia to conduct "lone-wolf" style attacks in their respective countries. For instance, in March 2014, an IJU commander claimed that they have a new project titled "Individual Jihad in the territory of Russia," and called on Muslims in Russia and Central Asia for "individual jihad." He said that "due to the difficulty of traveling overseas to conduct jihad, Muslims can perform their individual obligation (fard'ayn) of jihad from wherever they are. There

\section{"In May and June 2014, IMU suffered significant losses by Pakistani air force operations in FATA..."}

is a wide range of opportunities in Russia and Central Asia for successful jihadi operations." He also urged his followers based in Russia and Central Asia to focus on tactics and targets such as arson, attack on railway and vital energy infrastructures like gas and oil pipelines and electricity transmission grid. In another statement issued in December 2014, IJU explained the "importance" of "individual jihad." Nevertheless, in 2014, the IJU has focused more on targeting coalition forces in Afghanistan in order to secure and maintain support of Al Qaeda, the Afghan Taliban and other militant groups operating in FATA with the same agenda. It has carried out numerous assassinations in the northern and northeastern Afghan provinces such as in Takhar and Kunduz, areas with a significant Uzbek and Tajik population.

\section{Government Response}

Uzbekistan has put in place extensive counterterrorism programs and legislations to fight terrorism, religious extremism and the financing of terrorism. Uzbekistan has outlawed all unregistered religious groups and sects in its territory, and undertaken steps to stop the spread of radicalisation in the country.

In August 2014, the Uzbek Parliament adopted amendments to the law on online media that allow blocking of access to websites as well as blogs containing extremist content or those that promote illegal activities. It is an important step to address the use of the Internet as a tool of recruitment and spreading radical ideologies.

Religious scholars and clerics also have warned the public against supporting extremist and radical propaganda. For instance, in September 2014, Shaykh Muhammad Sodiq Muhammad Yusuf, the most prominent religious and spiritual leader in Uzbekistan, officially declared that "the ISIL [ISIS] defies Sharia law, and thus Muslims must not obey its orders." 


\section{Looking Ahead}

Although the threat from the IMU, IJU, JaK and JA has been minimised, their ties with Al Qaeda and the Taliban remain intact. These militants have strengthened by their experience of fighting coalition forces in Afghanistan, and have gained significant advances in tactics and strategy formulation as a result of its engagements and cooperation with other militant groups operating in the Afghanistan-Pakistan border region.

Although the two militant groups currently appear not to have enough capacity that would destabilise individual countries or the whole region, they still continue to pose a significant threat to both Central and South Asia, while carrying out sporadic attacks there. In pursuit of violent jihad, Central Asian militants are highly likely to remain limited in their appeal among their own countrymen. This is due to the fact that Muslims in Central Asia are averse to the militant groups' dogmatic insistence of an Islamic state. They are afraid of such ideologies largely due to the Tajik civil war in the past and developments in neighboring Afghanistan. With highly limited social base, these militants are unlikely to achieve the goals of overthrowing the secular governments in Central Asia.

However, as long as the conflicts in Syria and Iraq continue, the number of Central Asians travelling to join the "jihad" in these conflict zones will continue to grow. These battle-hardened militants may engage in terrorist activities in Central Asia upon their return to home countries.

In the long term, unless more viable solutions are considered, radicalisation of Muslims in Central Asia will likely to remain major security issues that the governments in the region will need to tackle. In order to effectively prevent further radicalisation of their populace, "soft approaches" also are needed. The governments should focus primarily on the prevention of radicalisation, with particular efforts to educate the youth. The youth in Central Asia have a rather rudimentary knowledge about Islamic concepts such as "jihad", "hijrah" and so on, which makes them very susceptible to indoctrination by radical influences. In addition to the importance of promoting moderate views through the media, the onus also lies with the Muslim scholars and clerics in Central Asia to educate the Muslims on Islamic concepts, so that they remain inoculated from radical Islamic ideas.

Nodirbek Soliev is a Senior Analyst with the International Centre for Political Violence and Terrorism Research (ICPVTR) at the S. Rajaratnam School of International Studies (RSIS), NTU. 


\section{East Asia}

Violent attacks continued to take place in China during 2014 in spite of enhanced security measures and economic and social development efforts in the restive Xinjiang Uighur Autonomous Region (XUAR). Uighur opposition to the Han Chinese dominance continues in China and the resurgence of jihadism especially in the Middle East and South Asia has given opportunity to groups like East Turkistan Islamic Movement (ETIM) to exploit the marginalisation - perceived or otherwise - of the Uighur to draw sympathy and support from fellow jihadists across the globe.

In 2014, China witnessed a number of attacks following the government's 9 September 2014 announcement of new anti-terror guidelines. On 21 September 2014 there were explosions at three locations in Luntai county in the region's south, including a shopping area. Middle East chaos also found its way into Xinjiang. On 3 September 2014, Iraqi authorities captured a Chinese national, believed to be a Uighur. The man was captured in the battlefield and was believed to have been fighting with the Islamic State of Iraq and Greater Syria (ISIS) militants.

The current spate of indiscriminate violent attacks in public areas, particularly railway stations, mostly targeted civilians from the Han Chinese community. On 1 March at least 29 civilians lost their lives and another 143 sustained injuries during a knife attack at the Kunming Railway Station in southwest of China. On 30 April, a bomb and knife attack took place at a railway station in Urumqi, Xinjiang, killing 3 and injuring 79 others. On 6 May as many as 6 people were wounded in a knife attack at a train station in China's Guangzhou city in the south. On 22 May, another bomb and knife attack at a railway station in Urumqi, Xinjiang, killed 3 and injured 79 others. On 22 May as well, in a brazen attack, 5 terrorists drove two sports utility vehicles (SUVs) into a market in Ürümqi, Xinjang, setting off explosives 
before crashing head on and exploding during the attacks. Eye witnesses reported hearing up to a dozen explosions. 31 people were killed and more than 90 others were injured. Although no particular group has claimed responsibility, the Chinese government has attributed the attacks to the ETIM.

On 30 July, Jume Tahir, a deputy president of the Xinjiang Islamic association, was stabbed to death. Tahir was a chief Imam at the city's main mosque and a former deputy to the official National People's Congress (NPC). Although it is unclear what motivated the killing of Tahir, the attacks highlighted a division between the local Uighur community and their state-backed Imams, who have supported many of the government's policies involving the Uighur population.

\section{Government Policies and Uighur Opposition}

On 24 August, China executed 8 people in Xinjiang for their involvement in what it called "terrorist" attacks. 3 of them were described as ETIM militants who were responsible for killing 5 people in a VBIED attack at Beijing's Tiananmen Square in October 2013. On 23 September 2014, a Xinjiang court sentenced a Uighur scholar Ilham Tohti, with life imprisonment after a brief two-day trial. Tohti had been running a website called Uighur Online and was detained shortly after the July 2009 Ürümqi riots for being critical towards the Chinese government's policies in Xinjiang.

In December 2014, Xinjiang's legislators passed a law prohibiting residents from wearing burqas in public in a bid to tighten its control over the Xinjiang's Uighur Muslim minority. Earlier, the state banned fasting by Muslim civil servants, teachers and students during the Islamic holy month of Ramadan. While Muslims perceive these measures as restrictions on their religious and cultural identity, the Chinese government defended the ban for the sake of good health of its employees. In reality however, these rather insensitive measures were in reaction to the escalation of violent attacks which Beijing attributed to the Uighur.

The Chinese government has also been investing heavily for the social and economic development of the province. Since 2010, hundreds of billions of Yuan have been allocated for Xinjiang's development until 2020. However, the benefits of these programmes do not go to

\section{"The current spate of indiscriminate violent attacks in public areas, particularly railway stations, mostly targeted civilians from the Han Chinese community..."}

the Uighur as most of the project related jobs and other benefits are being appropriated by the Han Chinese. Moreover, these efforts are overshadowed by Beijing's stringent and harsh policies vis-à-vis the Uighur.

\section{Uighur Jihadist Links}

As early as 2012, reports that Uighurs from Xinjiang were being trained in the AfghanistanPakistan border region and were being deployed to fight against Bashar al-Assad's regime highlighted the expansion of Uighur links to jihadists in Iraq and Syria.

There are in fact a number of Chinese fighters involved in the conflict in the Middle East. However, while some Chinese fighters are aligned with the ISIS, others are fighting with the Free Syrian Army (FSA).

A major portion of the Chechen, Uzbek and Uighur militants have formed a group distinct from Al Qaeda's Syrian affiliate Jabhat al Nusra against the Assad regime.

The new group, which is named Al-Muhajireen, has exposed the rifts between the Chechen and North Caucasian fighters and ISIS and other Islamists involved in the Syrian conflict, though in the past several of these smaller entities have fought alongside groups like Jabhat al-Nusra and the Islamic Front, particularly in key battles in north-western Aleppo and also Latakia. 
Front, particularly in key battles in north-western Aleppo and also Latakia. This could pose an added challenge for China's security as more militants are attracted to the join the fighting in Syria and Iraq due to different causes.

Uighur militants have also been establishing links with terrorists and extremists in Southeast Asia, especially in Indonesia. On 13 September 2014, Indonesia's Detachment 88 arrested four Uighur who had entered into Indonesia using forged passports.

These individuals reportedly had plans to receive training in bomb-making and weapon handling with the Indonesian terrorist group - the Mujahidin Indonesia Timur (MIT) led by Santoso, before returning to their country to launch attacks. Authorities found articles with the ISIS symbols in the vehicle that these Uighur and other 3 Indonesians were travelling in. Notably, MIT is one of the few groups in Indonesia that has pledged allegiance to ISIS.

The fact that Xinjiang shares cultural and linguistic linkages with Turkey and other states in Central Asia with large Turkic population is indication that Uighur discontent can have a rippling effect in the neighbouring countries.

ETIM's connections in North Waziristan in Pakistan have allowed its fighters to gain experience to fight in other conflicts such as in Syria and Iraq. Additionally, ETIM's close ties with the Mullah Omar-led Taliban (the Afghan Taliban) remains significant, particularly in view of the unfolding security concerns in Afghanistan after the U.S./ISAF draw down in 2014.

\section{Looking Ahead}

Amid signs of increasing radicalisation of the Uighur and militant elements establishing new cross-border links, especially for going abroad Iraq, Syria and Indonesia to name a few - to train and fight, Beijing's harsh counter-terrorism approach appears to be failing or leading to counter-productive outcomes.

\section{"Amid signs of increasing radicalisation... Beijing's harsh counter-terrorism approach appears to be failing or leading to counter-productive outcomes."}

Though the militant propensity of groups like ETIM and their links with jihadist groups in other conflict zones cannot be overlooked, there is a need for Beijing to revisit the roots of Uighur discontent which lie in the social, economic and religious marginalisation of the Uighur in Xinjiang. The grievances involving the Uighur in Xinjiang are being exploited by groups like ETIM and even al-Zawahri-led Al Qaeda Central (AQC). In fact, ETIM leader Abdullah Mansour had laid out Uighur grievances against China and compared Xinjiang to other areas of the world where jihadists were fighting, such as Palestine, Kashmir and more recently, Syria.

At the same time, radicalisation seem to be affecting non-Uighur Muslims, especially with a few Han Chinese converting to Islam and fighting in Syria. This is not discounting the fact that, Beijing would have to deal with these militants returning to China and carrying out attacks at home.

Beijing's huge investments for internal security and its international presence mostly in terms of trade and commerce, investments in infrastructure and other developmental initiatives in conflict affected countries have been impressive. 
Ironically, there has not been any perceptible peace dividend for China vis-àvis threats to its interests either at home or abroad. Contrarily, its counterterrorism policies have consistently been perceived to be oppressive, both by the militants that are hostile to China and by many members of the international community.

Under these circumstances, China needs to project a more transparent posture not only involving its counter-terrorism initiatives, but also in terms of its relations with other members of the international community. China's role in the Shanghai Cooperation Organisation (SCO), particularly in respect of counter-terrorism cooperation has been quite impressive. Beijing needs to expand these initiatives and continue to work closely with its neighbours and other concerned countries, in order to enable the government to put up a stronger and more effective front against few militants that appear to be bent upon destabilising the country.

Stefanie Kam is an Associate Research Fellow with the International Centre for Political Violence and Terrorism Research (ICPVTR) at the S. Rajaratnam School of International Studies (RSIS), NTU. 


\section{Middle East}

In 2014, Iraq's slide to chaos and potential disintegration continued further, with the hardening of the religious/sectarian and ethnic divides, and with groups like the Islamic State of Iraq and Greater Syria (ISIS) consolidating and expanding their presence in the country. In fact, ISIS' rise, consolidation and its metastasis as the so-called 'Islamic State,' have been one of the foremost developments in Iraq as it posed to challenge the peace and stability of the region and the world at large. The situation in Iraq also provided fertile conditions in support for a strengthened militancy - more broadly speaking, a renewal of jihadism - in Iraq as well as in the region.

\section{ISIS Phenomenon}

In early January 2014, the country witnessed a revitalised militancy which rapidly escalated with the declaration of the so-called caliphate under Abu Bakr Al Baghdadi, the leader of ISIS. ISIS' control of territory, especially of Mosul, the second largest city in Iraq, along with the strategic Mosul Dam and possession of military hardware taken over from the collapsing Iraqi army, highlighted the deteriorating state of governance in an already weak Iraq, under former Prime Minister, Nouri Al Maliki. ISIS was able to amass vast funds, mostly from the illegal sale of oil and natural gas and extortion, taxes collected from the population in the territory under its control and other criminal activities. Among the criminal activities carried out by ISIS, there was also the likely looting of US $\$ 425$ million from the Mosul branch of the Iraqi central bank. At present, ISIS controls Iraq's largest oil refinery in Baiji and thirteen oilfields in Nineveh, Al-Anbar, Salaheddiin, and Kirkuk (although most of Iraq's oil production, most of which in the South), are still under the control of the Iraqi government. 
The upheaval in Sunni areas of Iraq at the end of 2013 came mostly as a response to Nouri Al Maliki's order to arrest the Sunni parliamentarian Ahmad Al Alwani. Al Alwani was accused of inciting anti-government activity. The government's order to crack down a protest in Ramadi, the capital of Iraq's Sunni-dominated Anbar Province, further added to the anger among the Sunni. This led radicals among the community to capitalise on the growing sectarian divide in the country.

In ISIS militants' quest to seize Ramadi and Fallujah, as well as other smaller towns in the province, they were joined by Sunni protestors who defected from the Iraqi security services, the Baathists, as well as fighters from Sunni tribes. Many of these fighters from Sunni tribes had earlier served as a bulwark against radical groups like Al Qaeda in Iraq and Ansar al Islam, among others.

Up until June 2014, the insurgency in the Anbar Province in western Iraq may be judged to be a partial success. Although the government regained Ramadi, it failed in its attempt to recapture Fallujah. On 10 June 2014, ISIS fighters, along with scores of militants joining them from the Syrian battlefield, captured Mosul. The city fell easily to ISIS owing to the fact that many Iraqi security forces personnel either surrendered or deserted, as well as owing to the strong support for the militants by Mosul's Sunni residents.

After having declared the establishment of the Islamic State on 29 June 2014, ISIS subsequently made its advance down the Tigris Valley until Tikrit and Diyala Province, proceeding to capture Mosul Dam.

Over the summer of 2014, ISIS almost succeeded in encircling Baghdad from the north, west, and from the Sunni-dominated villages to the south in its offensive. The group was also rewarded with plenty of financial resources, as well as with arms and ammunitions. The group currently manages oil fields, raises tax from its citizens and ransom from captives, and is in possession of U.S.-supplied military equipment, including Humvees, tanks, and personnel carriers, captured from the Iraqi army.

\section{"Over the summer of 2014, the ISIS offensive almost succeeded in encircling Baghdad from the north, west, and from the Sunni- dominated villages to the south."}

The group has also sought to expand its gains in the Anbar Province by capturing the towns of Hit and Kusaiba at the beginning of October 2014, and is slowly advancing towards Ain al Asad airbase, which provides troops and supplies to the Haditha Dam.

In a similar fashion, ISIS is striving to proceed to Baghdad, and the militants captured the tow of Amiriya Fallujah and Qara Tappa at the end of October 2014.

The domestic counter-offensive against the ISIS has been mostly haphazard and deficient, adevelopment which has prompted the involvement of other countries, especially the U.S. The response has been focused on enlisting the support of the Sunni tribal groups, as the Iraqi security forces are in disarray and in many areas, completely disintegrated. Some of the Iraqi armed forces personnel have also reportedly joined ISIS.

However, the Sunni tribal leaders in the Anbar Province and the areas surrounding Baghdad are beginning to show signs that they are disenchanted with the limited support provided for by the Iraqi government and the U.S. 


\section{Ethnic Divide and Iraq's Religious Minorities}

ISIS has also taken advantage of the country's ethnic tensions. The Kurds belong to one of the world's largest communities. Many Kurdish populations stretching across Turkey, Iran, Iraq, and Syria have been fighting for an independent Kurdistan state.

Under the Saddam Hussein regime, the Kurds of Northern Iraq were also subjected to atrocities, which included chemical attacks. The new-found sense of empowerment by the Kurds after the removal of Saddam Hussein however, was shortlived, especially with the August 2014 dismissal of Iraq's President Talabani, who is of Kurdish origin.

With its offensives in North-Eastern Iraq, ISIS committed great atrocities against the Kurdish population. In early August 2014, it directly threatened the Kurdistan Regional Government (KRG), with its forces advancing into the Kurdish territory in Northern Iraq.

ISIS was able to overwhelm the poorly armed Peshmerga (armed Kurdish fighters). The towns mostly affected were Zumar, Wana, and Qaraqosh, where the fear of being executed by the ISIS or forced conversions has seen thousands flee from their homes.

ISIS also attacked Sinjar, an ancient town which was under Kurdish control ever since the Iraqi army deserted the area in June 2014. The ISIS offensive has resulted in thousands of Yazidis, who are mostly Kurdish, to flee to the Sinjar Mountain. This has triggered a humanitarian crisis.

The ISIS siege of Sinjar Mountain was reversed by U.S. airstrikes, along with the support from the People's Protection Units (Yekineyen Parastina Gel, also known as YPG) in Syria and Kurdish Workers Party (Partiya Karkeren Kurdistan, also known as PKK) in Turkey. Approximately 5,000 Yazidis were killed and thousands of women were kept captive and subjected to servitude or sex slavery. By 8 August 2014, the ISIS offensive nearly reached Irbil, the capital of the KRG.

\section{"With its offensives in north-eastern Iraq, ISIS committed great atrocities against the Kurdish population."}

Initially, in the aftermath of the group's capture of Mosul, scores of Iraqi Christians were forced to flee the city, as they were threatened to choose between forced conversion or execution. ISIS robbed over 1,500 Christian families at its checkpoints, while also confiscating their properties and turning Christian churches into mosques. Additionally, ISIS desecrated the ancient Christian center in Mosul and committed atrocities against the Assyrian Christians, Iraqi Turkmen, Shabaks, and Armanians, among others.

\section{Politics of Sectarianism?}

The outcome of the national parliamentary elections held on 30 April 2014 intensified ISIS' ruthless offensive. On 17 June 2014, the Iraqi Independent Higher Election Commission announced that Nouri Al Maliki's Shia-dominated coalition - State of Law - obtained a total of 92 seats, the Sunni candidates collectively obtained 53 seats, and the various Kurdish Provinces won 62 seats.

Nouri Al Maliki's attempt to obtain a third term as Iraq's Prime Minister was however hampered by the ISIS offensive, which most within Iraq and outside, (including countries like the U.S. and Iran), blamed on Al Maliki's divisive policies.

Indeed, after the departure of the U.S. forces in 2011, the Shia-dominated government under Nouri Al Maliki widened the sectarian divide, dispossessing and marginalising the Sunnis. ISIS exploited the sectarian divide, capitalising on the increasing tensions between the Sunnis and the Shias. 
Eventually, Nouri Al Maliki stepped down on 14 August 2014 and Haider Al Abadi, nominated by the Iraqi President Fuad Masum, became the Prime Minister. Unlike Nouri Al Maliki, Haider Al Abadi set out on a campaign to craft an inclusive governing structure, and hence a secure Iraqi society. He banned airstrikes from being conducted in residential areas and started recruiting key Sunni tribal leaders to the Iraqi security forces under the 'National Guard' program. Moreover, he ordered the Iraqi security forces to cease the shelling of Sunni-inhabited areas located within ISIS-controlled territories.

Nevertheless, Sunni tribal leaders claimed that there was a lack of substantial government support, while episodes of sectarian violence in Baghdad have been increasing day by day.

Under these circumstances, it is difficult to be optimistic that Haider Al Abadi's policies have been truly inclusive, satisfying all the factions and overcoming the sectarian and ethnic challenges successfully - even more so as Iraq's dependency on countries like the U.S. and Iran seems to be increasing.

\section{External Involvement}

Caught between the threat from ISIS and demands of the international community to manage the same, it seems inevitable that the Iraqi government may, yet again, have to reap the fruits of someone else's misdemeanour.

The involvement of Iran and the U.S. in Iraq's internal affairs might have similar consequences like the U.S. invasion of Iraq in 2003 - further inflaming the sectarian and ethnic issues. This is not discounting the roles and intricate dynamics of involvement of other regional countries such as Saudi Arabia, Egypt, Turkey, Syria, and others.

Following the ISIS offensives in both Syria and Iraq, the U.S. adopted a more interventionist agenda and has even put in place a coalition against the group in northern Syria and Iraq. In the aftermath of the attacks on the KRG's Peshmerga in August 2014, the Obama administration established a separate US weapons supply channel to the peshmerga forces.

\section{“ To be sure, 'degrading and ultimately destroying' ISIS requires ground offensives, together with airstrikes."}

Washington has also sent its own special forces, albeit as advisors, to train its Iraqi counterparts and to provide intelligence support.

But an increasing U.S. involvement could further complicate issues in Iraq. Airstrikes by the U.S.-led coalition may have reaped temporary successes against ISIS, but they have not been enough. Ultimately ground offensives are necessary and this is where the so-called coalition has fallen flat - no one is entirely committed to put 'boots on the ground.' To be sure, 'degrading and ultimately destroying' ISIS requires ground offensives, together with airstrikes.

While most agree on this, no one is sure how to go about it, due to domestic issues and compulsions in the respective countries involved, while foreign military intervention would only be acceptable upon the request of Iraq and Syria. Ultimately, it is likely that the U.S. intervention would lead to further alienation of Sunni tribes and an increase in sectarian violence in Iraq.

Another important aspect involving Iraq has been Iran's increasing influence. The Shia state has been supporting the Iraq political establishment, while its military assistance, including its own air campaign in Iraq to counter ISIS, often deemed necessary, has increased its hold over the Iraqi government. 
Moreover, Iran is also collaborating with Shia militant groups, such as the Badr Organisation or the Asaib Ahl al Haq, in order to both counter ISIS and consolidate its de facto leverage on Iraqi politics. In July 2014, Iran sent advisers from the Quds Forces of the Islamic Revolutionary Guard Corps to help the Iraqi security forces reorganise and expand the involvement of Shia militias.

This move stands in sharp contrast to the Iranian involvement during Nouri Al Maliki's reign, when the Iraqi government was rather elusive in respect of Tehran's involvement due to U.S. sensitivities. An increased presence of Iranbacked militias and Tehran's leverage over Iraqi policy-making could be counter-productive for Haider Al Abadi's efforts to dissipate sectarian tensions. This, in turn, may embolden the fractioned Sunni militancy to unite under ISIS.

\section{Looking Ahead}

Ultimately, Iraq's future hinges upon Haider Al Abadi's ability to create and sustain an inclusive government, address the sectarian and ethnic tensions, and work with partner countries to eliminate ISIS. At the community engagement level, this would entail the effective engagement with the Kurdish community to prevent more radical demands of separatism along sectarian lines. Furthermore, as the current effort to fight the Islamic State has evidently yielded temporary success, there is a need to build a political strategy accompanying the fight at the ground-level to help to weaken ISIS' support base and sympathisers.

Partnerships between the local actors, regional states, and the international community is also needed, in order to gradually weaken and degrade the ISIS' financial strengths, military mobility, leadership and its access to social media for recruitment and information operations, and in the long-run, to help ensure Iraq remains stable and territorially intact.

Aida Arosoaie is an Analyst with the International Centre for Political Violence and Terrorism Research (ICPVTR) at the S. Rajaratnam School of International Studies (RSIS), NTU. 
In 2014, events between the Israeli and Palestinian entities highlighted, yet again, the downsides of the mutual exclusiveness rhetoric shared by the Israeli authorities and Hamas. The interactions between the two, including negotiations have always been based on respective political dynamics rather than on a sincere desire to establish peace. Most importantly, these events frustrated the peace negotiations between the Palestinian Authority (PA) and the Israeli government, while eventually leading to a war between Israel and Hamas. The exchanges between both Israel and Hamas' signal their continued refusal to recognise one another as legitimate political actors, as a consequence political relations between Israel and Palestine in 2014 continued to be fraught with tensions.

\section{Frustrated Peace Talks}

Under the patronage of U.S. Secretary of State John Kerry, the Israeli Prime Minister and the Palestinian President kick started a series of peace talks in the summer of 2013 in Washington DC. The main purpose of the talks, as stated by John Kerry in January 2014 in Jerusalem, was to craft guidelines for permanent status negotiations, as opposed to an interim agreement. Nevertheless, the talks failed to address Hamas's role in a potential sovereign Palestine and the issue of illegal Jewish settlements.

Despite overall optimism, in 2014 peace talks between Israel and Palestine were repeatedly frustrated. In March 2014, the talks were halted as a result of Israel's defiance of a previously agreed timetable to release 26 Palestinian prisoners. Additionally, Israel announced plans to construct new settlements in East Jerusalem. Then, on 1 April 2014, President Abbas signed "State of 
Palestine" applications for 15 U.N. agencies, in a bid for further UN recognition of a state of Palestine. The move came despite a previous promise to suspend such efforts during nine months of negotiations with Israel. On 23 April 2014, Hamas and Fatah announced a reconciliatory deal legitimising the PA control over both Palestinian territories - West Bank and Gaza - and called for elections under the unified structure in 2015. Israel however responded by suspending the peace talks, claiming that Tel Aviv is not inclined to conduct talks with any government in consensus with Hamas.

\section{Negotiations Between the PA and Hamas}

Despite the Israeli attitude however, Fatah and Hamas focused on mending the internally fractioned Palestinian political scene. On 29 May 2014 Abbas asked Rami Hamdallah, a Fatah member, to assist in the creation of the National Reconciliation Government, an interim unity government. Initially, the appointment of Rami Hamdallah as Prime Minister sparked criticism from Hamas. However, the two parties reached a consensus and, on 2 June 2014, the interim government was sworn in but without any representation of Hamas therein.

Tensions between Hamas and Fatah were reignited when Abbas insisted that the Rami Hamdallah government abide by the "Quartet principles" which prescribes, among others, the recognition of Israel. This was however rejected by Hamas.

\section{The War Between Israel and Hamas}

Hamas began staging terrorist operations against Israel from the West Bank and abducted three Israeli teenagers in June 2014.The abduction and subsequent murder of the Israeli teenagers triggered the 50-day long war between Israel and Hamas. Israeli authorities claimed that the teenagers were kidnapped and later assassinated by two Hamas-linked Palestinians. Netanyahu's vow to react sternly to the murders emboldened a group of Jewish Israeli extremists to burn alive a Palestinian teenager in Jerusalem.

On 6 July 2014, violence between the Israelis and Palestinians reached a climax. As Israel carried airstrikes against a tunnel leading from Gaza, Hamas began firing rockets into Israel. Such violent retributive manoeuvres revealed the
“ On 26 August 2014 the war between Israel and Hamas officially ended with an Egyptianbrokered ceasefire. Although Hamas claimed victory, the devastations caused by Israel on the Gaza strip were enormous."

strong political dissatisfactions among the two actors. On the one hand Israel was increasingly frustrated by the failure of U.S.-backed negotiations and it detested the National Reconciliation Government. On the other hand Hamas was fed up with Israel's inconsistent statements on prisoners release and the siege of Gaza.

On 26 August 2014 the war between Israel and Hamas officially ended with an Egyptianbrokered ceasefire. Although Hamas claimed victory, the devastations caused by Israel on the Gaza Strip were enormous. The conflict resulted in the deaths of over 2,200 Palestinian while 11,000 others were wounded, with a civilian casualty rate of $75 \%$. Around 500,000 Palestinians were displaced and more than 17,000 homes were destroyed. Among the targets on the Gaza Strip were UN-run schools, Gaza's power plant and numerous civilian buildings. The overall cost for Gaza's restoration was estimated at $\$ 7.8$ billion. In contrast, Israel suffered 71 casualties, of which five were civilians.

Trust between Hamas and Fatah reached a low level as President Abbas commiserated with Israel and condemned the kidnapping of the Israeli teenagers. Contrary to Hamas's expectations, he tightened his security cooperation with Israel and allowed Israeli security forces to conduct manhunt operations in the West Bank against Hamas members. 


\section{Internal Palestinian Politics - a Priority}

Abbas perceived the war per se as a political strategy of Hamas to gain popularity, a move detrimental to the Palestinian Authority's support base. Realities on the ground required the PA to prioritise internal political settlements over relations with Israel. Abbas' popularity was sharply decreasing in the West Bank and the economic situation in both territories was worsening.

According to a poll released on 2 September 2014 poll by The Economist, support for Hamas in the West Bank had doubled from $23 \%$ to $46 \%$ since March 2014 while the same for Fatah's fell from $45 \%$ to $27 \%$. This would suggest that Hamas is gaining more legitimacy among the ordinary Palestinians. Nevertheless, experts have argued that Hamas's popularity boost is unlikely to significantly affect Abbas's de facto control of the West Bank. The latter still maintains the main source of funding, as the 177,000 West Bank employees provide support for around 1.5 million of Palestine's 4 million population.

Economic and political developments have led Abbas to acknowledge that tightening relations with Israel might affect his authority in both West Bank and Gaza. The West Bank economy was slowly sliding into recession and Hamas was gaining more recognition and legitimacy on the ground.

These factors ushered in the latest round of agreements on 25 September 2014 in Cairo between Hamas's leader and the Palestinian Authority. Hamas agreed to transfer control of Gaza's border crossings, the government machinery and the responsibility for reconstruction to Palestinian Authority.

Additionally, Hamas also consented to withdraw its militias from the 5-kilometre buffer along the border with Egypt and let Egypt help create a single armed force under Abbas's command.

\section{The Case for Palestinian Recognition}

Critics of the new reconciliatory rounds argued they were just a political stagecraft driven by financial considerations. There is the possibility that Hamas might give in to recognising Israel's existence. The reconciliation between Hamas and the Palestinian Authority helped project the image of an integrated Palestinian territory.
"According to a poll released on 2 September... support for Hamas in the West Bank had doubled from $23 \%$ to $46 \%$ since March 2014 while the same for Fatah's fell... This would suggest that Hamas is gaining more legitimacy among the ordinary Palestinians."

In addition to the 135 states that have already recognised Palestine, on 3 October 2014 the newly elected government in Sweden announced that it was ready to officially give Palestine the status it longs for. Also, on 13 October 2014 the British Parliament voted that Palestine should be regarded as a state with a motion carried by 274 to 12 .

Although this move bears no executive characteristic, the potential emergence of the Labour Party as the winning player in the British elections might put this motion into effect.

Such international responses to the Hamas and Fatah's compromises are likely to gain more support for the Palestinian state. Moreover, Hamas's attitude and the case of a war-torn Gaza Strip triggered a warm reaction from the international community. 


\section{Looking Ahead}

2014 was a very important year for the political situation between Israel and Palestine. Most importantly, the possibility of Hamas recognising the existence of Israel will shake off the mutual exclusiveness rhetoric. Much however depends on how Israel deals with the new found unity among the PA and Hamas. Judging by the international reaction to Gaza's devastation and the viral spread of motions on Palestinian recognition across countries, Israel might find it imperative to reconsider its stance - before any meaningful negotiations with Palestine can proceed.

Aida Arosoaie is an Analyst with the International Centre for Political Violence and Terrorism Research (ICPVTR) at the S. Rajaratnam School of International Studies (RSIS), NTU. 


\section{Middle East}

\section{Lebanon}

Chantal Azzam

In 2014, Lebanon witnessed significant problems relating to the influx of Syrian refugees, terrorist attacks and rising sectarian tensions, all of which have undermined Lebanon's fragile stability. The deteriorating situation in Syria has exacerbated internal issues that have already plagued Lebanon for decades.

\section{Spillover Effects from Syrian Crisis}

The refugee influx is the most visible and long-lasting spillover of the Syrian crisis. Due to Lebanon's open-border policy with Syria, a large number of refugees have moved into Lebanon. Unlike Jordan and Turkey, Lebanon has not put the refugees in camps. Therefore, refugees are spread over 1,600 informal settlements. Sixty per cent of the registered Syrian refugees are in the North and Beka'a Valley, the two poorest regions in Lebanon. The influx of refugees has posed a major concern for the country's law enforcement agencies, as their presence has stoked tensions in the country. Syrian refugees compete with Lebanese workers for jobs, particularly in the low-skill segments, seeking shelter and accommodation in the private housing market, and utilising already-strained public services and infrastructure in Lebanon. In terms of health security, owing to the large influx of refugees, cases of communicable diseases like polio have surged in addition to new diseases emerging in the country. On 23 October 2014, the government announced it would no longer accept Syrian refugees except with those with 'pressing' humanitarian reasons. 
There is evidence that some Syrian refugees have engaged in terrorism. Lebanon's Interior Minister Marwan Charbel asserted that some refugees are rebel fighters and therefore a threat to the country. Earlier Lebanese President also cautioned that Lebanon is facing a "crisis of survival" due to the influx of Syrian refugees. Hezbollah MP Walid Sakariya had previously remarked that refugees were carrying out "killing operations" targeting factions in Lebanon that support the Assad regime, while some are in the country to carry out "acts of sabotage." On 19 and 25 September 2014, the Lebanese army raided a number of refugee camps and arrested 450 refugees for alleged acts of terrorism. Thirty of them are now in prison.

The instability in the region has also seriously impacted tourism and trade sectors. Economically, the Lebanese economy is dependent on the Syrian economy because of the proximity of the two countries and their role as trading partners. The conflict has blocked all land routes for the Gulf Cooperation Council (GCC) countries to Lebanon. New travel warnings issued by a number of countries, including the U.S., against travelling to Lebanon has reduced the flow of Lebanese diaspora and travelers from GCC countries, severely impacting the tourism industry in Lebanon. Furthermore, the conflict in Syria has also heightened uncertainty and dampened consumer and investor confidence, significantly reducing the flow of foreign investment into the country.

\section{Threats to the Human Security of Syrians Refugees}

There has been rising violence by Lebanese citizens against the refugees, which has become more common and gruesome following the Arsal Crisis, a major battle in Arsal in eastern Lebanon on the border with Syria. The crisis was sparked on 2 August 2014, after Lebanese soldiers arrested Imad Ahmed Jumaa, the commander of a Syrian rebel group affiliated with the Al Qaeda-linked Jabhat Al Nusra (JN) or alNusra Front. In response, militants from IS and $\mathrm{JN}$ attacked and seized the northeastern border town of Arsal, which is home to thousands of Syrian refugees. Reportedly, Sunni militants entered the town of Arsal near the Syrian border and kidnapped 30 policemen and soldiers, executing 4 and releasing 7 eventually.

\section{"There has been rising violence by Lebanese citizens against the refugees, which has become more common and gruesome following the Arsal Crisis."}

Human Rights Watch documented 11 violent attacks in August and September 2014 against Syrians by Lebanese citizens, including drive-by shootings and arson attacks targeting refugee camps.

For example, on 7 December 2014, an unidentified man set to fire a refugee camp in Akkar. The attack was the second of its kind. On 6 December, Syrian refugee tents in Mashha were also burned down after local residents demanded Syrians leave the village. These attacks are attributed to the fact that most Syrian refugees are Sunni (about 96\% according to the UNHCR estimates).

\section{Terrorism Plagues Lebanon}

The Lebanese government had declared an official policy of neutrality and disengagement to the Syrian conflict. Nonetheless, in 2014, Hezbollah fully engaged in the fight alongside the Assad regime. Hezbollah's defense of the Assad regime however has mobilised Lebanese Sunnis to sympathise with their brethren who are opposed to the Assad regime.

In addition, a few among the Lebanese sympathisers of the Syrian revolution against the Assad regime feel that they are being 'unreasonably and unjustly' targeted by the Lebanese army, while Hezbollah has been able to send its members to fight openly - an instance which highlights the growing trend of Lebanese Armed Forces (LAF) soldiers defecting to join the fight in Syria. 
In October 2014, in a video statement, a Lebanese Army defector named Abdallah Shehadeh said that Hezbollah's "manipulation" of the military and its "discrimination" against Sunni personnel was what prompted him to join the $\mathrm{JN}$, an instance which highlights the growing trend of Lebanese Armed Forces (LAF) soldiers defecting to join the fight in Syria.

In October 2014, the LAF stated that three soldiers had defected to fight with terrorists. These include individuals like Abed-Elkader Akoumi and Mohammed Antar Habe who joined the Islamic State of Iraq and Greater Syria (ISIS) and Abdallah Shehadeh who joined the JN.

In this regard, militant activities in Lebanon can be attributed to the local Lebanese Sunni who sympathise with groups like the $\mathrm{JN}$ and the Islamic State of Iraq and Greater Syria (ISIS) and and joined the fight in Syria. In October 2014, LAF carried out raids in Tripoli, launching an assault with shells and gunfire and arrested 20 suspects with alleged links to ISIS and other groups.

Among those arrested was Ahmad Salim Mikati, who had been recruiting Lebanese to join the ISIS, and Rahman Hallak who with Mikati was making preparations to carry out a terrorist attack in the southern town of Saida. It is speculated the Ain al-Hilweh, Burj al-Barajneh, Sabra and Shatila Palestinian refugee camps have been used by ISIS and JN for training.

\section{Foreign Terrorists}

In January 2014, three prominent jihadi groups in the region - the Abdullah Azzam Brigades (AAB), JN and ISIS - issued coordinated statements declaring war on Lebanon and Hezbollah. Over the past fifteen months, Beirut's predominantly Shia southern suburbs have been the target of a number of VBID (Vehicle Borne Improvised Devices, or car bomb) attacks, killing over 75 people and injuring hundreds.

Despite infighting between the ISIS and JN in Syria, the situation in Lebanon is complicated with evidence of some ground-level cooperation between ISIS and JN in Lebanon.

The conflict in Lebanon had significantly escalated in August 2014 in Arsal. Given Arsal's strategic location, it has emerged as an

\section{"In October 2014, the LAF stated that three soldiers have defected to fight with terrorists...}

important support zone for jihadists in Syria, providing access to resources, reinforcements and sanctuary. Additionally, Arsal has also functioned as a staging zone to conduct reprisal attacks against Hezbollah targets within Lebanese territory.

$\mathrm{JN}$ and the ISIS have reportedly demanded the release of the Lebanese security force members, including several Islamists detainees from Roumieh prison by Syria and for Hezbollah to halt its military activities in the Qalamoun area of Syria.

In particular, $\mathrm{JN}$ is attempting to build up popular support for the Sunnis jihadists' by portraying Iran and its proxy Hezbollah as the aggressors in order to incite Sunnis in Lebanon to rise up against the Shiite forces.

$\mathrm{JN}$ and ISIS are also championing the cause of the Sunni, through demands for the release of the hostages and highlighting the plight of Syrian refugees in Lebanon. So far, Lebanese officials have refused to free the Islamists from Roumieh Prison but have promised to speed up trials of detainees awaiting trial.

\section{Looking Ahead}

As the Syrian conflict lingers, Hezbollah is likely to continue its military involvement in Syria. This however will exacerbate sectarian tensions and provide Sunni extremist groups the justification to intensify their attacks in Lebanon.

As the Syrian opposition is expected to gain greater ground in the North, it is expected that they will take the opportunity to militarise those elements of the Sunni population eager to push back Hezbollah's presence, placing the civilian non-combatants at a greater risk of acts of terrorism. 
Increased militarisation of the north may also draw northern Lebanon directly into the Syrian conflict by giving the Syrian army the justification to intervene.

Under such a situation, Lebanon needs to build a more nuanced counterterrorism strategy to strengthen its border control and prevent militant groups such as the JN and ISIS from entering into Lebanon. In addition, the Lebanese government would need to implement social and economic policies to alleviate the crisis involving the refugees in the country, even as the situation continues to place the country's infrastructure under strains.

Chantal Azzam is an Analyst with the International Centre for Political Violence and Terrorism Research (ICPVTR) at the S. Rajaratnam School of International Studies (RSIS), NTU. 


\section{Middle East}

\section{Saudi Arabia}

Aida Arosoaie

For Saudi Arabia, 2014 could be characterised as a year of inefficient politics. Significant threats to the Kingdom - terrorism and regional foes - were tackled from paradoxical standpoints and weak policies. Although Saudi Arabia took relatively firmer national and international counter-terrorism measures, the Kingdom continued its support for Salafist groups in Syria. Similarly, although it wishes to restrict the expansion of a Shiite Iranian influence in the region, the Saudis did little to maintain cordial relations with other Sunni states.

\section{Terrorist Threat and Political Dissent}

In 2014, the increasing terrorist threat emanating from Syria and Iraq compelled the Saudis to adopt a firmer counter-terrorism stance. On 31 January the Kingdom promulgated the Penal Law for Crimes of Terrorism and its Financing, creating the legal framework to criminalise virtually all dissident thought or expression as terrorism. Further, on 3 February 2014, King Abdullah issued Royal Decree 44 which expanded the law to criminalise participation in hostilities outside the kingdom, with sentences from three to 20 years in prison. On 7 March 2014, the Interior Ministry issued a list of groups the government considered terrorist organisations which included the Muslim Brotherhood, the Houthi group in Yemen, Al Qaeda in the Arabian Peninsula, Islamic State of Iraq and Greater Syria (ISIS), Jabhat al-Nusra and Hezbollah.

However, the main downside of the penal law is the potential of sparking a statewide political uprising. The vague draconian laws threaten the rights of peaceful assembly and entitle judges and prosecutors to use it against independent activists. For example, in early July a prominent Saudi Arabian lawyer and human rights defender, Waleed Abu al-Khair, was sentenced to 15 years of prison under the new law. Such actions have the potential to further stir political dissent in the Kingdom, proving detrimental to domestic stability. 
Although the scenario of a political uprising represented a Saudi nightmare, the terrorist threat was visibly greater. In May 2014, the Saudi authorities announced that they had uncovered several terrorist plots aimed at assassinating government officials and attacking local and foreign assets within the country. The investigations indicated that the perpetrators were collaborating with Saudi nationals who joined the ISIS. Saudis make up the second most populous nationality in the ISIS, with over 2,500 adherents.

Under such circumstances, Saudi authorities accelerated the pace of their counter-terrorism efforts. In June and July 2014 Saudi Arabia increased troops across the border with Iraq. During the month of Ramadan, Saudi authorities announced they were investigating 17 clerics who failed to denounce terrorist activities within and outside of the Kingdom.

In early August Saudi Arabia contributed to international counter-terrorism efforts by donating US\$100 million to the United Nations Counter-Terrorism Centre, further adding to King Abdullah's strategy of making the Kingdom an active player in international security. On 23 September Saudi Arabia officially joined the US in an airstrike campaign against ISIS in Syria. The Kingdom participated with four F-16 fighter jets and agreed to provide training for 5000 Syrian opposition rebels. Though the airstrike campaign failed to put much dent on ISIS's progress, Saudi participation together with other Muslim countries made the U.S.-led campaign more legitimate from the perspectives of the Muslims in the region.

\section{Salafism - Friend or Foe?}

Kingdom's longtime support for Salafism has historically been a matter of concern. As a Sunni literalist movement, Salafism provided Wahhabism, its ideological base. Thus, in projecting Wahhabi Saudi Arabia as the guardian of true Islam, the Saudis supported Salafis all around the world. It was only later that Salafism morphed into a very radical sub-movement whose adherents include terrorist groups such as Al Qaeda, Boko Haram, Al Shabaab and the ISIS. Since the start of the Syrian conflict, Saudi Arabia's extensive support for the rebel Salafist opposition in Syria had gradually culminated in the creation of the Islamic Front in November 2013.

\section{“ In early August, Saudi Arabia contributed to international counter-terrorism efforts by donating US\$100 million to the United Nations

\author{
Counter-Terrorism \\ Centre..."
}

The Islamic Front brought together six of the most prominent Sunni-Salafi opposition groups. The Kingdom actively participated in its creation, justifying its actions by antagonising the Qataribacked Al Qaeda-affiliate Jabhat al-Nusra (JN).

Throughout 2014, Saudi Arabia provided substantial military and financial support to these groups, while also agreeing to train around 5000 of their militant cadres as part of its commitment to the U.S.-led airstrike campaign against the IS and the other extremist factions.

\section{Iran - Saudi Arabia's Arch rival}

In addition to its determination to fight Al Qaeda and its affiliates in Syria, the Saudi support for the Sunni militancy is also a product of its proxy war against its arch rival, Iran. The strongest supporter of the Alawite minority governing Syria, Iran also has a firmly established presence on the Iraqi, Lebanese and also the Yemeni political scenes. In particular, Iran's interference in Yemen in 2014 provided a threat to Saudi Arabia's security establishment.

On 21 September Sanaa, the capital of Yemen, was seized by the Houthis, a Shiite minority group heavily backed by Iran. This revitalised Al Qaeda in the Arabian Peninsula - the group's biggest unit in the region - which is likely to 
propel the country into a sectarian battlefield similar to that of Syria and Iraq.

Increasingly worrisome for Saudi Arabia was the insurgents' capture of a Yemeni crossing point into the kingdom on 20 October 2014. In response to the Yemeni crisis Saudi Arabia placed its forces on high alert, reinforced security along its 1,800 kilometre border with Yemen and publicly warned against any insurgent incursions into its borders.

Moreover, Saudi Arabia's concerns regarding Iran's virtual foothold of Yemen and Syria have been exponentially accentuated by the growing uncertainty regarding Iran's nuclear arsenal. The nuclear talks between Iran and the world powers on the former's nuclear programmes were initially scheduled to terminate on 20 July 2014 , then postponed to 24 November 2014 and then again extended.

\section{Qatar - The Improbable Ally}

Instead of strengthening the Sunni camp in order to fulfill its strategy against Iran, in 2014 Saudi Arabia unwittingly stepped up its longtime dispute with Qatar. The policy mismatch between Saudi Arabia and Qatar regarding political developments in Egypt had increased tensions between the two states.

Qatar is the only Gulf state which strongly supports the Muslim Brotherhood, backed by the Morsi government. During last year's regional crackdown on the Brotherhood, Qatar refused to ally with its Gulf Cooperation Council comembers. In complete opposite, on 7 March 2014, Saudi Arabia declared the Muslim Brotherhood a terrorist organisation. The Saudis also began exercising pressure on Qatar to drastically curb the coverage of Al Jazeera, the only remaining popular channel extensively covering the Brotherhood story in Egypt.

Qatar's refusal to obey resulted in Saudi Arabia, together with two of its allies, the UAE and Bahrain, withdrawing its ambassador from Doha. The Kingdom also hinted that it might adopt increasingly stringent measures, including closing its borders and airspace. The greatest implication of this diplomatic crisis is the potential to undermine the regional power exercised by the member states within the Gulf Cooperation Council (GCC).

\section{“ On 21 September Sanaa, the capital of Yemen, was seized by the Houthis, a Shiite minority group heavily backed by Iran. This revitalised Al Qaeda in the Arabian Peninsula."}

The GCC member states have met in the second half of the year in repeated attempts to forge a strategy to compel Qatar to stop backing the Islamists. The lack of any positive developments saw Qatari Emir al-Thani travel to Jedda on 13 October 2014 in order to convince King Abdullah that he has implemented all the demanded steps.

Despite the former's plea, the King remained unconvinced. Such mistrust might strongly affect the capability of the GCC to take concrete steps in the region against extremism, disintegrating states and, most importantly, against an escalating sectarian influence.

Furthermore, Saudi Arabia's frostier relations with Qatar in 2014 might consistently amount to instability in the region - a consequence made even more undesirable in the context of Iran's increasing power hold.

\section{Looking Ahead}

As ISIS resists the U.S.-led coalition and sectarian violence in Yemen looks to be rapidly escalating, Saudi Arabia is not headed towards a bright 2015.

The same can be said in the context of Iran becoming a nuclear power and if tensions with Qatar will continue to worsen. Saudi Arabia has an unprecedented chance to emerge as a political leader of an internally war-torn Middle 
East. Nevertheless, due to its contradictory policies in 2015 the Kingdom is likely to remain at odds with its enemies.

The Saudis might see a new wave of terrorist attacks coming from both the nationals who joined the Islamic State group and those who joined the ranks of Al Qaeda in the Arabian Peninsula in Yemen. Moreover, the Saudis might also fall prey to power politics and further perpetuate its conflict with Qatar at the expense of Iran's expanding influence. Given the death of Saudi King Abdullah bin Abdulaziz in late January 2015, it is uncertain whether his successor can transition smoothly to the throne and take charge of the country. Domestically, the country is undergoing a period of fragile instability, in addition to having to deal with international concerns, more specifically with regards to Iran's nuclear program, and the US negotiations with the Iranian government.

Aida Arosoaie is an Analyst with the International Centre for Political Violence and Terrorism Research (ICPVTR) at the S. Rajaratnam School of International Studies (RSIS), NTU. 


\section{Middle East}

Dragged into its fourth year, the Syrian conflict which began in 2011 has seen the deaths of more than 205,000 people. The general course of the complex war has changed significantly since 2013 , as the fighting has moved into a new phase, with the Syrian government and the Islamic State of Iraq and Greater Syria (ISIS) evenly matched in terms of their respective capabilities.

In 2014, ISIS gained extensive territory in both Iraq and Syria, killed thousands of civilians, and persecuted thousands more. Due to 'ISIS' continuing brutalities, a United States-led coalition of at least 62 countries was established in August 2014 to "degrade" and then "destroy" ISIS. Soon after its formation, the coalition conducted aerial bombings against targets in Syria, and then in Iraq, to weaken the ISIS-held Kurdish areas, as well as training camps of other militant groups in the region. In retaliation, some members of the group, including the so-called 'Jihadi John,' threatened the United States, Canada, United Kingdom, France, Germany, and all other countries that joined the U.S.-led coalition to fight against ISIS.

Civil war is worsening in Syria, amidst a dense web of clashing militant groups. Thousands of foreign fighters also continue to stream into Syria to join the war, most of them joining ISIS or the Al Qaeda-affiliated Jabhat al Nusra (JN) (' Support Front for the People'), also known as Al Nusra Front. The bulk of the foreign fighters have come from Algeria, Morocco, Saudi Arabia, Tunisia, and Turkey. Experienced and extremely radicalised, these fighters have become a crucial part of ISIS and JN, and a key element in the Syrian conflict. Some foreign fighters have joined the Kurdish militias in northern Syria, i.e., the People's Protection Units (Yekineyen Parastina Gel: YPG), the armed wing of the Kurdish Democratic Union Party (Partiya Yekitiya Demokrat: PYD), to fight against ISIS. 


\section{Main Parties of the War}

Currently, the total number of fighters in Syria is estimated at several hundred thousands. The fighters are divided among hundreds of groups, large and small, fighting in Syria. Even so, it is possible to divide them into four main groupings, which represent the four main 'sides' of the war: (1) Syrian government and its allies and supporters, (2) ISIS and Al-Qaeda-affiliated groups such as Jabhat al Nusra (JN), Ahl al Sham, Mujahideen Shura Council, and the Khorasan Group, (3) Syrian opposition, and (4) the Kurdish front.

The first grouping is the Bashar Al Assad government, its allies and its supporters, which is represented by more than thirty militant groups and brigades with approximately 250,000 fighters. It is known that about 10,000 foreign fighters in support of the Syrian government are from the Lebanese Hezbollah militant group and that a few thousand have come from Iran.

Thus, the Syrian government and its supportive groups are the biggest force on the ground in the Syrian war, and allegedly have armament support from Russia, Iran, China, and North Korea, and non-lethal military support from Venezuela. This grouping newly emerged as a winner in the Syrian conflict in 2014, especially as the Islamist terrorist groups in the forefront ISIS and JN - were weakened due to airstrikes by the U.S.-led coalition.

The Bashar Al Assad government has been able to extend its boundary to the borders of Turkey once again, while in 2013 the country's borders had effectively pushed inward as the government lost control of Syrian territory near the Turkish border.

The second grouping in Syria's raging war is ISIS and the Al Qaeda-affiliated jihadist terrorist groups. The groups in this category never fight with each other, and sometimes make alliances against other groups. The key strength of these groups is the continuous flow of experienced, highly radicalised, and determined foreign fighters that join them, substantially augmenting the operational capacity of the groups.

Approximately 60,000 fighters are believed to have joined ISIS and JN, and at least 15 percent $(9,000)$ of them are believed to be foreign fighters. However, ISIS and JN are deemed to be on the decline due to the U.S.-led coalition

\section{“...thousands of foreign fighters also continue to stream into Syria to join the war, most of them joining ISIS or the Al Qaeda-affiliated Jabhat al Nusra (JN)."}

attacks on their strongholds and training camps, as well as due to the increased control of border crossings, which has diminished the recruitment of foreign fighters. Nonetheless, these groups continue to carry out offensive operations in an effort to prove their might and to attract new fighters, and in such cases, the groups are able to gain some ground.

For example, the JN capture of key army bases of the north-western province of Idlib, with a huge amount of weapons, in mid-December 2014 , is a great danger to the Idlib city centre and threatens government control of the area. The Islamist terrorist groups purportedly have armament support from Turkey, Qatar, Saudi Arabia, and Libya.

The third grouping in the Syrian conflict comprises the approximately 70 militant groups, small and large, of 'Syria's opposition.' This front has in total about 50,000 fighters. Backed by Western states, the groups belonging to this front is the most varying and uncoordinated.

This grouping is undergoing internal turmoil, as each group has its own leader and its own program, and thus lacks direction and centralised decision-making. The views of the groups are so discordant that the only factor which places them under one umbrella is their common opposition to the Bashar Al Assad government. 
Presently, however, as ISIS is being seen as the biggest danger by the U.S.-led coalition, the Syrian opposition has been more focused on fighting ISIS than the Syrian government. The militant opposition groups lost control over the city of Homs in May 2014, which was known as the capital of the 'Syrian revolution,' and has been under the control of the Syrian opposition front since the beginning of the war in 2011. In a new development, an alliance of 72 factions belonging to the Syrian opposition was established on 3 August 2014, and named the Syrian Revolutionary Command Council. The alliance was formed in an effort to increase the coordination and unity between the many different Syrian opposition groups, although there have been similar attempts in the past. Harakat Ahrar al Sham al Islami ('Free Islamic Movement of Sham') and JN were excluded from the Council, while the Free Syrian Army has rejected it. Although it is too early to gauge the potential success of the council, similar but unsuccessful attempts in the past suggests that it is likely to fail in establishing unity between the many different ethnic and religious groups.

The fourth main grouping in Syria is the Kurdish front. Constituted and organised in early 2012, this front almost immediately constructed the necessary political, economic, and security infrastructure in areas under its control known as 'Rojava,' which consists of the Jazira, Kobane, and Afrin cantons in northern Syria, as well as established an armed forces named the People's Protection Units (Yekineyen Parastina Gel: YPG) - the total number of fighters being about 50,000 . This front is an alliance between some of the Syrian Kurdish groups which claim self-rule over the Kurdish populated areas of northern Syria, and are opposed to Syrian President Bashar Al Assad. The cantons under the control of the Kurdish front are also inhabited by other ethnic groups such as Arabs, Assyrians, Chechens, and other groups. The Kurdish front has been fighting against ISIS since its establishment. It was engaged in intense fighting for more than three months after the first ISIS attack on the town of Kobane on 16 September 2014, which was aimed at capturing Kobane and breaking the Kurdish resistance in the area.

\section{"Damascus is a point where ISIS struggles with other militant groups in addition to government forces..."}

\section{Mapping the Conflict}

\section{Damascus}

There are continuing battles involving the four fronts described, and there is fluctuating control of frontlines by them. The dynamics of some of the main battlegrounds are described next, which shed important insight into the Syrian war.

Damascus, the capital city of Syria, is still under the control of the Syrian government. Fighting continues between government forces and opposition fighters. The government uses intensive airstrikes against the militants to maintain control of the city centre and its outskirts. Surprisingly the daily life in the city has not been disrupted; education, government facilities, and health services continue for the local population.

Infighting among the different armed opposition groups has increased, and Damascus is a point where ISIS struggles with other militant groups in addition to government forces.

The control of Damascus is of course vital for the government - and for any opposition group in the long-term - as it is the main stronghold of the government, as well as a well-situated and symbolic city of great historical significance. However, it is unlikely that any militant group fighting in Syria will gain control of Damascus in the near future, as Damascus remains the seat of the Syrian government. 


\section{Aleppo}

Aleppo, the biggest city of Syria, fell into chaos and war in July 2012, as rebel forces took control of some districts of the city. The Syrian Army, however, regained control of most of the city from October 2014 with intensified offensives, which included airstrikes, and was successful in repelling the militant forces. In early October 2014, government forces broke the siege of a prison in Aleppo by opposition groups, and by mid-October, more than 14,000 fighters of the Free Syrian Army and other opposition forces retreated from the city. The city is still an ongoing battlefield, and residents of the city suffer frequent water shortages and constant power cuts. Each major group has an area of control in the city at present, but government forces are on the offensive, gaining control of more and more areas, while the opposition and jihadist forces hold a defensive position.

\section{Homs}

The third biggest city of Syria, Homs, known as the capital of the 'revolution,' has been under the control of opposition forces since 2011, but government forces gained control of the city in May 2014. However, as a main theatre of sectarian violence, government forces could not quell anti-government protests, and conflicts erupted across the city. Some government soldiers defected, and protesters took to the streets with their arms, intensifying the fight between the government and the opposition forces. Yet, the government retains control over the city. Taking back Homs was a key achievement for the Syrian government in 2014.

\section{Kobane}

Kobane, a Kurdish-populated township that borders Turkey, has been a main target of ISIS since 16 September 2014. By 2 October 2014, ISIS had succeeded in capturing more than 350 Kurdish villages in the rural areas of Kobane, which caused the displacement of more than 300,000 people, who in turn fled to Turkey. Kobane was besieged by ISIS from three sides, using tanks, rockets, and heavy artillery against the lightly-armed Kurdish People's Protection Units (YPG) forces, the armed wing of the Kurdish Democratic Union Party (PYD) of northern Syria.

\section{“Presently, the intense fighting continues between ISIS and YPG and Pershmerga forces, backed by the US-led coalition's airstrikes, in Kurdish areas in northern Syria and is causing ISIS' gradual retreat out of Kobane."}

ISIS easily advanced to the city centre with its heavy weaponry. On 27 September 2014, the U.S.-led coalition began airstrikes on ISIS in Kobane, although ISIS continued its advance for forty more days. However, reinforced by Peshmerga forces (Kurdish fighters of the Kurdistan Regional Government of northern Iraq) - the YPG was first able to stall ISIS, and then begin advancing against it. The YPG and Peshmerga forces, combined with airstrikes by the U.S.-led coalition, succeeded in pushing back ISIS from most of Kobane by the end of December 2014.

The fight for Kobane was a milestone in the fight against ISIS, particularly because for the first time, ISIS could not capture a relatively small town with all of its heavy weaponry.

The resistance by the Kurdish forces of Kobane with their light weapons, generated worldwide attention and support, and on 1 November 2014 - dubbed 'Global Day of Kobane' - hundreds of thousands of people took to the streets all around the world in support of the Kurds of Kobane.

Presently, the intense fighting continues between ISIS and YPG and Pershmerga forces, backed by the U.S.-led coalition's airstrikes, in Kurdish areas in northern Syria, and is causing ISIS' gradual retreat out of Kobane. 


\section{Deirez-Zur}

In Deirez-Zur, the largest city in eastern Syria, there is on-going fighting between the government forces and ISIS. Half of the city, including the air base, is under the control of the Syrian government.

Unlike in the past, sudden raids on government installations by ISIS are proving less effective for the group, as government forces are reacting more aggressively to the attacks. Deirez-Zur is another battlefront where ISIS has got stuck, and is neither advancing nor retreating. In the future, government forces may be able to recapture the whole of the city, as continuing airstrikes weaken ISIS by the day.

\section{Humanitarian Crisis}

The many fronts of the Syrian conflict have caused the internal and external displacement of millions of people. More than 10 million people have been displaced since 2011, 3.5 million of which have gone to neighbouring countries such as Lebanon, Turkey, Jordan, and Iraq. Furthermore, three out of four of Syrian refugees have been women and children, mostly widows and orphans.

In 2014, hundreds of thousands of people were displaced due to the fighting, most fleeing to neighbouring countries due to the fear of torture or slaughter by ISIS in Syria. On the other hand, life has never been easy for the refugees who have fled to other countries; only a small segment of Syrian refugees stay in refugee camps, while most live in desperate conditions suffering from hunger, lack of shelter, and insecurity. Meanwhile, host countries find it difficult to cope with the refugee influx, and will only be able to maintain their assistance to Syrian refugees with the help of international humanitarian and development organisations in the future.

\section{Looking Ahead}

At present, it is difficult to set a date for the end the Syrian conflict. Neither is it easy to determine the outcome. This is further aggravated by the fact that, the conflict has drawn a large number of fighters from different countries, raising the fear that these fighters might carry out attacks in their respective countries upon their return.

Direct and indirect international intervention into the Syrian conflict has also been a major obstacle in achieving the right solution for Syria. At present, the majority of Syrians support the Bashar Al Assad government, as they understand that there is still no better alternative for the country. The Syrian opposition, unfortunately, is not united to form a stable government if the present one falls. Thus, as Syria continues to burn, so will the concerns to security and stability in the Middle East, and the rest of the world continue.

Mekki Uludag is an Analyst with the International Centre for Political Violence and Terrorism Research (ICPVTR) at the S. Rajaratnam School of International Studies (RSIS), NTU. 


\section{Middle East}

\section{Syed Huzaifah Bin Othman Alkaff}

Yemen entered 2014 with many security challenges, such as the separatist movement in the south, the sectarian power struggle in the north, and the increasing threat from terrorist groups such as Al Qaeda in the Arabian Peninsula (AQAP), and its affiliate Ansar al Sharia ('The Supporters of Islamic Law). Power struggle and lethal factionalism within the military and security apparatus also contributed significantly to instability in the country. The National Dialogue Conference (NDC), the key initiative taken by the country to support the political transition from former President Ali Abdullah Saleh's 33year rule, concluded in January 2014, but with the northern and southern separatist movements rejecting the NDC and most Yemenis hoping more of economic relief than political reform.

\section{National Dialogue Conference (NDC)}

The National Dialogue Conference (NDC), brokered by the Gulf Cooperation Council (GCC) and the United Nations (UN) under the chairmanship of Yemeni President Abdrabbuh Mansour Hadi, commenced in March 2013 and reached a conclusion in January 2014. The NDC was set up to assist the country in its political transition. To this end the NDC undertook the task of holding discussions on proposals for state-building, with the end goal of adopting a new constitution to address widespread political and socioeconomic grievances under the previous regime. The NDC brought together 565 delegates from diverse political parties and social groups, and included nine main channels of discussion, in the form of thematic working groups. 
The NDC was successful in getting the new constitution adopted with the agreement of all the participants, reflecting President Abdrabbuh Mansour Hadi's vision of a new political system inclusive of various political factions, tribes, religious, and social groups. The constitution also provided for limited autonomy for some regions. However, while the President believes that the conference has lessened the bloodshed in the country, most Yemenis remain sceptical less concerned about the political aspects of governance and expecting rather an end to corruption in the government and greater economic opportunities for the people.

\section{The Houthi Rebellion}

The highlight of the threat to Yemen in 2014 was the continuing armed uprising of the Houthis in the north, despite the efforts by the NDC. The Houthis reject NDC's plan to federalise the country into six regions, as they believe that it would only serve to divide the country into rich and poor regions. On 21 January 2014, the same day the NDC came to a close, Ahmad Sharafeddin, a Houthi NDC representative and former dean at the Law Faculty of Yemen's premier Sanaa University, was assassinated. Abdel Malek Al-Houthi, the leader of the Houthis accused the Al-Islah party for the killing although the latter rejected the accusation and strongly condemned the assassination urging the government to bring the perpetrators to justice.

The Shia Houthi militants, known as Ansar Allah ('Supporters of God'), have been fighting in Yemen since 2004 for greater autonomy in the region, which they had been enjoying for the past millennium. After the 1962 revolution, Sunnis took over and centralised power, dispossessing the Houthi. Though there were a number of protests by the Houthis interspersed with ceasefires since 2011, militants took advantage of the political instability in the country when the then President Ali Abdullah Saleh stepped down in 2012 to intensify their efforts to gain autonomy.

The Houthis have stated that they are antigovernment and anti-repression, although they are also looking to have greater autonomy for their heartland of Saadah province under an inclusive government. Although they follow the Shia Zaydi doctrines, the Houthis, claim to support a republican state structure where power rests with the people. However, there is a concern that given the autonomy, the Houthis
"By end September 2014, the Houthis had stormed through Sanaa and seized government buildings, state media facilities, and military bases."

would most likely adopt a governance system based on Islamic theocracy much more like the one in Iran.

In late July 2014, the Houthis staged demonstrations and protests on the outskirts of Sanaa and other provinces in the north demanding the removal of fuel subsidies and urging the formation of a new government. Despite casualties, Houthis continued to fight the military en route to the capital claiming to defend the Houthi neighbourhoods and reached Sanaa in September 2014. The Houthis also fought the army in the Mareb and Jawf provinces.

By end September 2014, the Houthis had stormed through Sanaa and seized government buildings, state media facilities, and military bases. This led to an estrangement between the army and the government and the resignation of the Prime Minister Mohammed Basindwa, who was later replaced by Khaled Baha - Yemen's envoy to the United Nations. Control over the capital gave the Houthis some leverage in dictating terms and pressuring the government for a power-sharing agreement.

Again in January 2015, Shiite Houthi rebels were in apparent control of all the major institutions in Yemen's capital, Sanaa, after they seized the presidential palace and shelled the residence of President Abed Rabbo Mansour Hadi. The rebels took charge of a military base that housed ballistic missiles, and posted guards outside Hadi's residence. A day after, multiple reports alleged that the Shiite's had struck a deal with Yemen's president. The coup had apparently left the president under no control, and this was followed by an agreement which called for the 
Houthi rebels to withdraw from parts of the capital, Sanaa, including the presidential palace, and to free Hadi's chief of staff, Ahmed Awad bin Mubarak, whom they had abducted.

In exchange, Hadi agreed to demands which reportedly included redrafting the constitution to specify that Yemen is a federal state. The January seizure and subsequent concession highlighted the likelihood that the Houthis - who have been fighting against the government since 2004 and claim they are fighting for the rights of Yemen's Zaydi Shiite Muslim sect - might be emboldened and continue applying these same means of political pressure to gain concession for their demands in the coming months ahead, further placing the political authority of the President under strains.

Al Islah, the main opposition party in the country voiced out against the Houthis, as they felt that they have been left out and since the Houthi leader blamed the Al Islah party for all of the country's ills and rampant corruption. Al Islah also blamed Yemen's President Hadi as being responsible for Yemen's deterioration as well as for Sanaa succumbing to the Houthis demands.

Houthi rebels to withdraw from parts of the capital, Sanaa, including the presidential palace, and to free Hadi's chief of staff, Ahmed Awad bin Mubarak, whom they had abducted. In exchange, Hadi agreed to demands which reportedly included redrafting the constitution to specify that Yemen is a federal state.

The January 2015 seizure and subsequent concession by the Yemeni president highlighted the likelihood that the Houthis - who have been fighting against the government since 2004 and claim they are fighting for the rights of Yemen's Zaydi Shiite Muslim sect - might be emboldened and continue applying these same means of political pressure to gain concession for their demands in the coming months ahead. Evidently, the political authority of the president had been placed under huge strains, as was seen in his resignation in the days following the seizure.

Al Islah, the main opposition party in the country voiced out against the Houthis, as they felt that they have been left out and since the Houthi leader blamed the Al Islah party for all of the country's ills and rampant corruption. Al Islah also blamed Yemen's President Hadi as being responsible for Yemen's deterioration as well as for Sanaa succumbing to the Houthis demands.
“In March 2014, AQAP established an armed group called "Ansar Al Shariah Fi Al-Manateq Al -Wusta" (Partisans of Islamic Law in the Central Regions) with the aim to fight the Shia Houthis that were based in the Saadah province."

\section{AQAP Threat}

In addition to the $\mathrm{Al}$ Islah, $\mathrm{Al}$ Qaeda in the Arabian Peninsula (AQAP) also fought against the Houthis. In March 2014, AQAP established an armed group called "Ansar Al Shariah Fi AlManateq Al-Wusta" (Partisans of Islamic Law in the Central Regions) with the aim to fight the Shia Houthis that were based in the Saadah province. The new group is believed to be a subgroup of Ansar al Shariah in Yemen.

Groups like AQAP claim that the government has too much in its support to the Shia Houthis, and all its counter-measures against Al Qaeda and other like-minded groups in the country serve the interests of the Houthis and the Shia. For AQAP the Shias are heretics. AQAP and its affiliate Ansar al Shariah have conducted many attacks against the Houthis, in areas and checkpoints they control.

The jihadist groups like AQAP aim to expulse Western/ modern influence and replace the secular 'apostate' government of Yemen with a fundamentalist Islamic government that implements Islamic Law. The presence and activism on the part of groups like AQAP has greatly exacerbated the sectarian divide and has also been detrimental to the peace-building process in the country and its economy. 
AQAP has also been a threat to the region and the world at large. It has been encouraging fighters from Yemen and elsewhere to join the war in Syria to fight against the Syrian government. AQAP also urged jihadi groups in Syria to unite against Western countries, especially the US which has been targeting the group and its leadership for a long time.

\section{Southern Secessionists}

The separatist movement by the Yemeni Arabs, also known as Al Hirak Al Janubi in the south of the country has also been a matter of concern in 2014. The southerners believe that they have been marginalised politically and economically, and have been protesting since 2007. They too have rejected the NDC proposed federal structure for the country; instead demanding for independence. In addition, the southerners claim ownership of the land that the non-southerners traditionally own.

For the central government however, Al Hirak is a violent separatist movement and a grave threat to national security, especially as the country's largest oil reserves are in the south.

\section{Looking Ahead}

The threat from extremism and terrorism has almost led the country to the brink of a failing or a failed state with the sectarian battle between the Sunni Salafists, including the AQAP and its affiliates, and the Shia Houthis worsening by the day. At the same time, implementation of NDC's proposals that hold prospects of peace and stability is incumbent on the involvement of all the parties, factions, tribes and groups in the country.

Cooperation, compromises, and trust between them is an imperative that cannot be overestimated. Yemen also needs the support of the international community to degrade the threat from AQAP. Eventually, everything depends on how inclusive the government can be with policies aiming at social cohesion, economy progress and ultimately political stability in the country.

Syed Huzaifah Bin Othman Alkaff is a Senior Analyst with the International Centre for Political Violence and Terrorism Research (ICPVTR) at the S. Rajaratnam School of International Studies (RSIS), NTU. 


\section{Middle East}

\section{Qatar}

Aida Arosoaie

Since the shift in leadership in 2013, with Tamim bin Hamad Al-Thani succeeding his father Hamad bin Khalifa Al-Thani, Qatar has adopted a more interventionist approach to regional politics. The moves become significant in light of the current political turmoil in the Middle East and North Africa. Despite its shortage of human resources, Qatar's wealth and its desire for influence has led it to adopt a proxy war politics strategy, with the aim of furthering its influence as a leader of Sunni Islam.

To a considerable extent, its past involvement, albeit indirect, in Libyan, Egyptian and Tunisian politics, has established Qatar in the eyes of its regional neighbours as a peace broker. However, in 2014 Qatar seemed to be moving away from this posture and, instead, has indirectly contributed to the political destabilisation of the region.

Countries that benefitted from Qatari aid have been experiencing deteriorating political milieus, the most prominent being Libya, with its present state of war with militias. Also, Egypt is severely affected by an uncertain transition from authoritarianism and Syria has become home to one of the most complex conflicts in the region. In 2014, Qatar continued to get involved in these ongoing conflicts. Most notably, unconditional support for the Muslim Brotherhood and strong support for Salafi extremists in Syria stood out as Qatar's main foreign policy pivots in the year 2014. 


\section{Qatar, the Muslim Brothers and the GCC}

While the Saudis and its close allies perceive the Muslim Brotherhood to be a direct threat to their domestic security, Qatar has generously extended its support for conflicts occurring from Libya to Egypt, and from Tunisia to Syria. Considering Doha's longstanding relation with the Muslim Brothers, Qatar sees the organisation as an important ally for increasing its own influence throughout the region.

However, with the overthrow of Morsi's Muslim Brotherhood regime in July 2013 Qatar started experiencing the negative side effects of its proxy politics. With Saudi Arabia, the UAE and Kuwait's strongly support for the Egypt's militarybacked interim regime led by al-Sissi, the Egyptian conflict emerged as the flashpoint of a rift in relations between the Gulf Cooperation Council, of which Qatar is a member state. The three Gulf States demanded Doha to cease its support for Islamists, considerably curb the biased coverage Al Jazeera gave to the Brotherhood and to halt all media references to the events in July 2013 as a coup d'etat. Moreover, on 5 March 2014, Saudi Arabia, Bahrain and the United Arab Emirates recalled their ambassadors from Doha as a sign of protest over Qatar's patronage of the Muslim Brotherhood. Although representatives of the Qatari government publicly expressed their revolt at the Saudi and UAE demands regarding the emirate's conduct of foreign policy, Doha tacitly understood that the situation could escalate into a severe crisis within the GCC.

Despite its struggle to overtake Saudi Arabia as the leader of Sunni Muslims in the region, Doha recognises that its position in the GCC is crucial for expanding its influence in the region. On 13 September 2014 Qatar requested seven senior members of the Brotherhood to leave Doha, giving in to several months of increasing pressures from its neighbours to stop supporting extremist Islamists. Furthermore, on 25 September the Qatari government instituted a new law to regulate domestic charities in order to prevent them from engaging in financing militant groups.

On October 2014, Emir Shiekh Tamim bin Hamad Al Thani flew to Jeddah. Although Qatar seems to have met all of the demands put forward by King Abdullah, the latter remained skeptical regarding Doha's claim that it has completely stopped financing terrorist groups.
"Over the last 15 years, Doha has established itself as an operating hub for the greatly interconnected Salafist community whose members live in Qatar, Saudi Arabia, Bahrain Kuwait and other states in the region."

This is an especially critical aspect in view of claims that Qatar continues to support Jabhat alNusra, Syria's Al-Qaeda affiliate. As of now, it remains unclear whether Qatar's increasingly interventionist approach to regional politics will prove detrimental to its overall advance as a regional political power. However, judging by the reactions of its Gulf neighbours vis-a-vis its support for Salafist activities, it is likely that Qatar's wealth and multiple, sometimes conflicting affiliations, might in fact become a factor for undermining peace rather than brokering it.

\section{Qatar and the Salafists}

Over the last 15 years, Doha has established itself as an operating hub for the greatly interconnected Salafist community whose members live in Qatar, Saudi Arabia, Bahrain, Kuwait and other states in the region. Such old ties became extremely useful for Qatar in 2013 when it decided to start infusing huge amounts of financial support into extremist Salafi movements in Syria, with notable examples being Jabhat anNusra and Ahrar al Sham.

Qatar's intervention in Syria was closely modelled after its Libyan strategy to support Islamist factions against the reigning leader, thereby increasing its influence. While the Libyan dictator Gaddafi was successfully removed from power, however, this was not the case in Syria. The unanticipated turn of events regarding the 
presidency of the Arab League offered Qatar the opportunity to play an organising role over the conflict.

As the February 2011 Arab League summit was postponed, Doha successfully managed to secure another presidency term. The Arab League suspended Syria's membership and imposed political and economic sanctions on Assad's government.

Qatar adopted a more direct approach only when the sanctions against Bashar al-Assad turned out to be insufficient. Doha organised its middlemen in a network of support similar to the one in Libya in order to handle the rebel capacity on the ground. However, despite the generous Qatari funding, rebels failed to make any significant progress. The emergence of Islamic State of Iraq and Greater Syria (ISIS), has shed light on the political affinities on the ground, and further revealed how competition between Saudi Arabia and Qatar has fractioned the opposition, much to the detriment of the overall Syrian uprising.

Doha's decision to join the U.S.-led coalition against ISIS in Syria and Iraq is also significant. Now referred to as Operation Inherent Resolve, the air campaign was initiated on 8 August 2014 and was also aimed at destroying $\mathrm{Al}$ Qaeda affiliates in Syria. Qatar, the nominal U.S. ally, provided the use of its Al Udeid Air Base to the coalition. Moreover, Qatar is one of the five Arab countries to have formally joined the air campaign with two Mirage jet fighters, but the only one which has yet to fire a single shot. Under these circumstances, diplomats from other Arab states have publicly warned Washington that Qatar is playing a double game in the region.

In support of these accusations, the U.S. Treasury revealed on 24 September that Qatari money has been used to support "military operations" by Salafist groups such as Jabhat al-Nusra and ISIS. Further, the U.S. Treasury disclosed that about US $\$ 2$ million raised by an ISIS senior commander, Tariq bin al-Tahar al-Harzi, was obtained from Qatari nationals.

\section{Looking Ahead}

Throughout 2014, events in the region have given the newly established Qatari leadership a hard time in terms of deciding on its foreign policy decisions. The country had channeled its wealth and support towards Islamist groups around the region with the aim of securing its sphere of influence. However, its unabashed support for the Muslim Brotherhood has caused trouble with fellow Arab states and undermined the GCC's role in the region. Also, its tacit support for the Salafi opposition in Syria might hinder the core goal of the U.S.-led air campaign in the region destabilising the region.

Aida Arosoaie is an Analyst with the International Centre for Political Violence and Terrorism Research (ICPVTR) at the S. Rajaratnam School of International Studies (RSIS), NTU. 
Egypt currently faces major security challenges with frequent attacks on civilians and security forces by non-state armed (NSA) groups. The sudden political upheaval, brought on due to the 2011 popular uprising, the failure of the democratically-elected President Mohammed Morsi to build an inclusive government, the unwarranted eviction of Morsi on 3 July 2013 by a military coup and the subsequent designation of the Muslim Brotherhood as a terrorist organisation by the end of 2013, paved the way for the proliferation of terrorist activity and acts of violence in the country.

The year 2014 has seen the highest number of terrorist attacks since the resignation of Hosni Mubarak in 2011. According to the report Egypt's Security: Threat and Response by the Tahrir Institute for Middle East Policy (TIMEP), the general trend in terror violence has remained consistent, with an average of 27.3 attacks during the month of January up until September 2014.

Egypt's Sinai Peninsula continued to suffer from the highest number of terrorist attacks. The 2014 TIMEP report revealed that in 2013, 225 attacks, or 67 percent of the overall number, took place in the Sinai Peninsula, specifically, in the north of the region. In 2014, the number dropped to 80 attacks or 38 percent of the overall number of terrorist attacks in Egypt. Although the Sinai remains the area with the highest concentration of attacks and terrorist activity, the Giza and Cairo governorates have been increasingly targeted, with 20 percent, and 15 percent, of the overall number of attacks in 2014 respectively. 
There was a decrease in civilian casualties due to a shift toward government targets at the end of 2013. However, there were more civilian casualties again in 2014. The targeting of civilians has always been a tactic of Egyptian terrorist organisations.

\section{Al Qaeda Network in Egypt}

Despite the pledge of allegiance by Ansar Bayt al Maqdis (ABM) ('Supporters of the Holy House') to the Islamic State of Iraq and Greater Syria (ISIS) in November 2014, Al Qaeda Central (AQC) has continued to spread its influence in Egypt since the 2013 removal of President Morsi. On 24 January 2014, AQC leader Ayman Al Zawahiri urged through an audio statement for AQC affiliated entities "in the Sinai...to offer sanctuary to [their] brothers, the Mujahideen." Although the exact relationship between $A Q C$ and the other terrorist groups in Egypt is difficult to ascertain, recent evidence suggests that $\mathrm{Al}$ Qaeda in the Sinai Peninsula (AQSP), the Muhammad Jamal Network, Al Salafiya al Jihadiya ('Salafi-jihadist Movement') (Sinai), Al Tawhid wal Jihad ('Monotheism and Holy War' group) (Sinai), and the Mujahideen Shura Council in the Environs of Jerusalem, have some level of connectivity and ideological affiliation with the former. AQSP is allegedly strongly linked to Al Qaeda in the Arabian Peninsula (AQAP) and Al Qaeda elements in the Gaza Strip, as well as some groups in Pakistan and Afghanistan.

\section{ISIS Influence}

In a video released in September 2013, a Sharia court judge of the ISIS in Syria addressed his "Mujahideen brothers in Sinai" and stated that "You and we are one [...]." Similarly, attempts by ISIS to spread its influence in Egypt continued in 2014. Significantly, in April 2014, Egyptian military officials mentioned the possible relocation of some ISIS senior operatives to the Sinai Peninsula. Also, in addition to its pledge of allegiance to ISIS, ABM is suspected to have sent two senior operatives to Syria in October 2014 to meet with the ISIS leadership. ABM is believed to be responsible for the deadliest attack on the Egyptian military on 24 October 2014, which killed 30 soldiers. On 1 December 2014, two ISIS-affiliated jihadist media outlets posted a six-page propaganda piece on Twitter calling Muslims to help consolidate the ISIS "caliphate's province" in Egypt.

\section{“ Despite the pledge of allegiance by Ansar Bayt al Maqdis ( $A B M)$ in November 2014, Al Qaeda Central (AQC) has continued to spread its influence in Egypt since the 2013 removal of President Morsi."}

\section{Terrorists at Home}

Ajnad Misr ('Soldiers of Egypt') is a Giza-based group which has been professing Salafi-jihadist ideology and targeting government personnel and assets. The group has not been linked to any other terrorist organisation and most of its members are young locals. Despite releasing an audio message pledging an allegiance to Ayman Al Zawahiri, the group members seem to have little knowledge on the global jihadist ideology and its implications.

The group conducted approximately fifteen attacks in greater Cairo in 2014 with increasing sophistication. Ajnad Misr claimed responsibility for an attack that killed eight and wounded ninety on the anniversary of the 2011 uprising on 24 January 2014. Although Anjad Misr is a low-level threat group in Egypt, it has the potential to motivate other groups comprised of young Egyptians to carry out attacks and to turn toward a Salafi-jihadist ideology. 


\section{Regional Component of Terrorism}

The increasing competition between diverse jihadist groups, especially those with a global reach, to mobilise radical Muslims is also affecting Egyptian security. In January 2014, Egyptian authorities voiced their concern about the swelling numbers of foreign fighters coming in to Egypt. Various reports recount Afghans, Yemenis, Syrians, Saudis, Libyans, Algerians, and Sudanese joining radical groups in the Sinai Peninsula to fight against the Egyptian government and Israel. In addition, weapons coming from Sudan in the south, Libya in the west, and Gaza in the east, have further destabilised Egypt and strengthened the capabilities of the militant groups. Some weapons consignments transit only through Egypt.

\section{Counterterrorism in Egypt: Mishandling the Sinai}

Since mid-2013, Egyptian authorities have been waging a relentless campaign against terrorist elements in Sinai. Officials claim they are winning their battle against terrorism. Between late January and early March 2014, there was some success with approximately 75 militants killed by multiple air strikes, dismantling of their safe houses, and confiscation of a massive cache of weapons, which included explosives.

Since the Mubarak administration, peace in the Sinai has been buttressed through the cooperation between the government and the Bedouin tribes. The Bedouins have provided security for industrial sites and pipelines throughout the Sinai Peninsula, and have helped mediate crises involving diverse militant groups. For instance, in May 2013, seven soldiers were released unharmed due solely to Bedouin negotiation with the kidnappers.

However, many Bedouin tribal leaders have been assassinated by terrorist groups throughout the years. This has been attributed to the postMubarak regimes that apparently have lost their grips on the overall security structure, as well as intelligence capabilities in the peninsula due to the deteriorating relationship with the Bedouin tribes.

\section{"Since the Mubarak administration, peace in the Sinai has been buttressed through the cooperation between the government and the Bedouin tribes...}

More specifically, the trust between the two has eroded as a result of the heavy-handed measures adopted by the military that have failed to differentiate between militants, criminals, and law-abiding citizens. Tribal elders are becoming increasingly reluctant to assist the government in maintaining security and gradually seeming to be turning toward $\mathrm{Al}$ Qaeda and other radical groups based on mutual financial interests and ideological sympathies. This is facilitated by Al Qaeda in the Sinai Peninsula (AQSP) by distributing pamphlets which address specific tribal grievances. Furthermore, Salafist groups have been actively recruiting and radicalising the Bedouin youth. For example, Shady Al Menaei, an ABM field commander, is originally from the Menaei clan of Sinai's large Sawarka tribe. Egyptian intelligence officials also believe that the Bedouin and militant groups are collaborating in arms, drugs, and human trafficking operations, as a means to fund terrorist activities.

\section{Egypt's War on Terrorism}

Like by many governments of the world, the measures adopted by the Egyptian government to combat terrorism circumvent international conventions and treaties that it has ratified, including the Geneva Conventions, and the Convention against Torture. The military regime led by Abdul Fattah El Sisi has not addressed the urgent need for political reform, but has instead adopted repressive measures to combat terrorism and diminish criticisms of the regime.

Torture, a long-term problem in Egypt, currently appears to be rampant. Since the ousting of President Mohamed Morsy, Egyptian security forces have used excessive force frequently, leading to the worst incident of mass unlawful 
killings in Egypt's recent history. Judicial authorities have bequeathed unprecedented large-scale death sentences and security forces have carried out mass arrests and torture that harken back to the darkest days of former President Hosni Mubarak's rule. Further, authorities have enforced extensive restrictions on freedom of association, expression, and assembly, which has dramatically reversed gains made following the January 25, 2011 uprising. Trampling on fundamental rights won't make the country safer. Respect for human rights and security needs to be at the heart of the battle against terrorism.

The new anti-terrorism law approved by Egypt's cabinet, on November 2014 to expand the definition of terrorism under the Egyptian penal code, has been criticised for further violating human rights, in turn, threatening human security. The amendments to 17 articles of the penal code define terrorism to include actions that could "obstruct" the work of public officials, or universities, mosques, embassies, or international institutions. Article 86 of the penal code, as amended, would criminalise any "intimidation" that could "harm national unity," prevent the application of the country's constitution or laws, or "damage the economy."

Moreover, the amendments require that anyone convicted of aiding or belonging to groups that "harms national unity or social peace" may be sentenced up to 10 years in prison. By this definition, anyone who takes part in the uprisings in 2011 or 2013 could be branded a terrorist. The issue with these vaguely worded 'terrorist offences' is that they potentially allow the authorities to bring a terrorism case against virtually any peaceful activist. Moreover, it violates the right to free expression, undermines safeguards against torture and arbitrary detention, and expands the scope of application of the death penalty.

The anti-protest law No. 107 adopted in 2013, the detention of activists and journalists, the criminalisation of the Muslim Brotherhood and mass arrests of its members, and the crackdown of student protesters, are seen as repressive measures by the state. While authorities should be empowered to fight terrorism and its sponsors, as well as groups the inciting of hatred and extremism, the rights and security of the people at large must be at the heart of any

\section{"The military regime led by Abdul Fattah El Sisi has not addressed the urgent need for political reform but rather has instead adopted repressive measures to combat terrorism and diminish criticisms of the regime."}

security measure or operation. Otherwise, the fear of the authorities and lack of freedom could be counter-productive at the least.

\section{Looking Ahead}

Egypt's counter-terrorism campaign is at risk in both the near and long-term if the government fails to match its security efforts with measures to address the grievances of the Egyptians on political and developmental issues.

Unless the authorities change course and comply with commitments to respect citizens' rights and the rule of law, the future of Egypt looks bleak. Tensions had surged in January 2015, ahead of the anniversary of Egypt's 2011 revolt which saw the ousting of strongman Hosni Mubarak. Protestors and security forces clashed on 25 January 2015, leaving at least 15 people dead in Egypt. In Cairo, demonstrators, mostly suporters of Morsi, clashed with police, leaving 13 protesters dead. Protests also took place in the Mediterranean city of Alexandria, in Central Cairo, in north Cairo, and in downtown Cairo. In downtown Cairo, police fired shotguns and tear gas against hundreds of protesters who tried to march on the central Tahrir Square, the epicentre of the early 2011 revolt. Despite extra security in the capital, including armoured vehicles stationed around Tahrir, 
militants set off a bomb in eastern Cairo's Alf Maskan neighbourhood, wounding two policemen. The militant group Ajnad Misr (Soldiers of Egypt) claimed both blasts. Two suspected militants were also killed when they mistakenly blew themselves up in an attempt to sabotage an electricity tower in the Nile Delta province of Baheira.

In the near future, the growing influence of the two main global jihadist groups over the Sinai Peninsula as a strategic location may transform the area into a safe haven or transit zone for foreign fighters in the region. This, coupled with the existing tunnel network to and from Gaza and the flow of weapons and fighters into the Sinai, will have long-lasting repercussions on the security of the region. Moreover, the Egyptian decision to intervene in the Libyan conflict and expand the buffer zone between Egypt and Gaza comes at the expense of the local population, and the country needs to consider the possible security implications that will arise from the likelihood of it backfiring, leading to an increased intensity of retaliatory attacks in 2015.

Thomas Chenesseau and Chantal Azzam are Analysts with the International Centre for Political Violence and Terrorism Research (ICPVTR) at the S. Rajaratnam School of International Studies (RSIS), NTU. 
More than a year after taking power on 14 December 2012, Libya's postGadaffi government faced a bleak outlook at the onset of 2014. The diverse militias who were once instrumental for removing Muammar Gadaffi from power in 2011 have themselves become the country's greatest security concern today. At the same time, Libya underwent tumultuous elections in 2014 , the outcome of which further divided the country.

\section{Libya - conflict within}

Throughout 2013, the government struggled to control numerous militias, who were either nationalist or Islamist in their disposition. It is estimated that there are about 1,700 different armed militias in the country, many of them controlling small areas of their own. The struggle continued, even increased in 2014 , with violence, especially assassinations targeting top army and security officials - plaguing the entire country.

A weak central government has also led to the rise in militants and criminal elements flocking to the country, especially to "Salvador Triangle" in the south - a no-man's land along the porous border between Libya, Algeria and Niger. This area is used by traffickers and smugglers to move armaments and fighters between North Africa and countries in sub-Saharan Africa. It is also reported that several militant groups have set up camps in this area to train and fight in Mali, Iraq and Syria. 


\section{Political Divide and Violence}

On 12 January 2014, Deputy Industry Minister Hassan Al-Droui was assassinated by unknown gunmen. Al-Droui was a former member of the National Transitional Council, the political arm of the 2011 uprising. This was the first assassination of a member of the transitional government. Though no one claimed responsibility for the attack, Libya's militias were blamed.

In February 2014, two of the more powerful militia groups - al-Qaaqaa and al-Sawaaq called on legislators to step down after the Libyan parliament, the General National Congress (GNC), scheduled to retire on 7 February 2014, extended its mandate until elections, due to be held in June 2014. The extension was orchestrated by Nouri Abu Sahmein, who chaired the GNC and was trying to stay in power despite being opposed by the nationalist militias.

The political situation devolved into further turmoil when liberal Prime Minister Ali Zeidan was sacked on 11 March 2014 and Abdullah AlThani, the Defence Minister, assumed the office. However, Abdullah Al-Thani was soon replaced by Ahmed Maiteeq in a controversial and disputed move which split the GNC.

In mid-May 2014, in an unprecedented move the former general and nationalist leader, Khalifa Haftar carried out "Amaliah Karamah" or "Operation Dignity" by his armed group - the "Libyan National Army" - aimed at neutralising extremists and terrorists in Benghazi. Haftar blamed the parliament for allowing terrorists to mushroom in the country.

He and the militia from Zintan, a strong body from one of the largest cities in north-west Libya, attempted to dissolve the GNC with the demand that the judiciary take charge of the country's affairs until the scheduled elections in the end of June 2014. General Haftar's move was backed by former Libyan Prime Minister Ali Zeidan, tribal gunmen, other militias especially the Zintanis and other Libyans and Arabs who prevented the GNC from blocking elections on 25 June 2014.

\section{"...The struggle continued, even increased in 2014, with violence especially assassinations targeting top army and security officials plaguing the entire country."}

\section{A Sway in Legislative Election}

On 25 June 2014, legislative elections were held and resulted in a significant loss for many Islamist candidates that dominated the previous parliament. The old GNC was replaced by a new parliament, the House of representatives and out of the 200 seats, Islamists won only 30 leading to a nationalist and liberal oriented government.

Haftar's involvement in the conflict also led to the people switching sides to support him and throw their vote behind the nationalists. However, soon after the elections, lawmakers were targeted by rival militia groups, especially the Islamists, who launched "Operation Libya Dawn" and seized the Tripoli International Airport in August 2014.

Libya's official Parliament the House of Representatives, was forced to retreat from the capital, setting up a government in Tobruk. This has left Libya with two governments, one in Tobruk and one in Tripoli, each battling to get the support of the country and its myriad militias. 


\section{Two-Sided Struggle}

The current conflict can generally be seen to be revolving around two sides - the nationalist proHaftar, and the pro-Islamists who support the Islamist factions in the GNC. Haftar has quite substantial numbers of army and air force personnel in his ranks who have defected to join him, which has given Haftar the advantage of being able to launch air strikes.

As a former general, Haftar himself has established his own armed group called National Army. In addition, he is supported by the Zintani militia, arguably the second most powerful armed force after the Misratans (from Misrata, another city in northwest Libya) who are allied with the Islamists.

Among the pro-Islamist groups is the Libyan Revolutionary Operations Room (LROR) that was created in 2013 as the control center of Libya Shield Force, an alliance of pro-Congress militias. Libya Shield Force was established in 2012 temporarily for integrating militias into a cohesive national force.

Another group is Ansar Al-Sharia, based in the east and aiming to establish a caliphate in the country. Ansar al Sharia has extreme views against the constitutional government and democracy. Finally, the Misratan forces, arguably the most powerful militia in the country, formed a key part of the Libya Shield Force that backed the Islamists in Congress.

The country is also divided mainly into five conflict zones. Zintan, located 160 kilometers southeast of Tripoli and situated in the Nafusa Mountains, is a stronghold of armed groups who are allied with General Haftar. Tripoli itself, the capital city where the ousted GNC has set up a rival government, is a battleground with a strong presence of "Libya Dawn".

The third area is Misrata itself, the third largest city. The Misratans are led by Salah Badi and they are against Haftar and his allies. Benghazi, the second largest city is under the control of Ansar Al-Sharia and its allies, who are fighting against Haftar and his allies for control over military and civilian airports.
"The current conflict can generally be seen to be revolving around two sides-the nationalist pro-Haftar, and the proIslamists who support the Islamist factions in the GNC."

Finally, Tobruk, a port city on the eastern Mediterranean coast, remains the base for the internationally recognised government, the House of Representatives that Prime Minister Abdullah Al-Thinni headed after the defeat of Islamist candidates in June elections.

\section{Disruptions in Oil Production}

Libya underwent an oil crisis in late 2013 to mid 2014 as the government lost control over key facilities, including ports, which controlled the country's oil production and distribution network.

Despite an attempted blockade and threats by the government, the militias were able to sell the country's oil although they claimed that its profits would provide their areas with resources and development which had been neglected by the government for so long. Prime Minister Ali Zeidan's sacking was partially due to the government's inability to control the oil ports.

The new government elected in mid 2014 had originally struck a deal with militias to let the government regain access to the oil terminals, and in return the government assured the groups that it would pay compensation to the rebels, drop charges against them and reverse its threat of a military offensive.

Unfortunately, since the newly elected government was rejected by their adversaries in the country - the Islamists - the deal went sour as the government did not have sufficient power to enforce it. 
Disruptions to the oil industry have not only been caused by the militias but also from oil workers themselves. Strikes were frequent in 2014 with workers demanding increases in salary. Libya's oil industry was badly affected with losses estimated to be around US\$3billion a month. Furthermore, due to heavy fighting especially in several airports such as Benghazi and Tripoli, and the deterioration of overall security in 2014, many UN staff have been evacuated from the country. Many of the embassies have also shut and foreigners evacuated.

\section{Looking ahead}

Despite the general Islamist-nationalist divide, the conflict in Libya appears to be dominated by power politics, with each group angling for an eventual piece of the governmental pie.

More often than not, the main motive for fighting among diverse groups has been either money or power, although religion has been an additional mobilising factor. The conflict between nationalist and Islamist has also been dominated by a rivalry between Zintanis and Misratans. Without at least a basic consensus involving key governance issues, democracy would continue to elude Libya.

Syed Huzaifah Bin Othman Alkaff is a Senior Analyst with the International Centre for Political Violence and Terrorism Research (ICPVTR) at the S. Rajaratnam School of International Studies (RSIS), NTU. 
The year 2014 presented a challenging security landscape for Nigeria, with Boko Haram attacks in the Yobe, Borno, and Adamawa states in northeastern Nigeria and Abuja, as well as instances of communal violence in the Benue River Valley in central Nigeria. In the south, militants in the Niger Delta embarked on a series of abductions, demonstrating that despite the gains of the post-amnesty program, a militant movement may re-emerge in the region. The security implications of the forthcoming general elections are also increasingly precarious.

\section{Boko Haram Terrorism}

Nigeria continued to grapple with the Boko Haram ('Western education is forbidden') terrorist group which conducted attacks throughout 2014, across northern Nigeria and beyond. Boko Haram seeks to implement an extremist interpretation of Islamic Law or Sharia in Nigeria, and in 2014, intensified attacks both on Christian and Muslim targets, as well as to schools. Government offices, diplomatic institutions, and security agencies were also targeted. Boko Haram employed the element of surprise and asymmetric warfare in its attacks against the Nigerian state, using ambush, suicide bombings, drive-by shootings, and the blasting of bridges to frustrate counter offensives, as well as carrying out intelligence and reconnaissance operations in the conduct of attacks. The territory held by Boko Haram has also become a theatre for both the importing and exporting of terrorism to and from countries bordering Nigeria, and beyond. 
A large section of the country's 4,900 km which it shares with Cameroon, Chad, and Niger are porous and under-patrolled. This has remained a source of vulnerability and continues to facilitate the cross-border movement of terrorists and transnational trafficking such as the transit of illicit drugs, smuggling in contraband goods, and the proliferation of small arms and light weapons.

It is estimated that over 12,000 persons have lost their lives to Boko Haram since 2009, and that over 2,000 individuals have been killed by Boko Haram in 2014. There were four key terrorist incidents executed by Boko Haram in 2014: (1) the attack on the Federal Government College of Buni Yadi in Yobe State in north-eastern Nigeria on 25 February 2014, which led to the death of 59 students; (2) the bus station bombing of 14 April 2014 in Nyanyan which caused the death of 71 civilians, in southwest Abuja, Nigeria's federal capital territory; (3) the abduction of 276 school girls from the Government Secondary School of Chibok town in Borno State in north-eastern Nigeria on $14^{\text {th }}$ to $15^{\text {th }}$ April 2014; and (4) the abduction of 185 women and children from the Gumsuri village in Borno state in mid-December 2014.

Other major attacks by Boko Haram in 2014 include the bombing of Banex Plaza, a shopping mall in Abuja in June 2014, which killed at least 21 individuals, and recurrent attacks in towns like Azare, Bauchi, Gombe, Jos, and Kanoin, in the Borno, Adamawa, and Yobe states in November and December 2014, with a cumulative death toll of over 200.

In June 2014, Abubakar Shekau, leader of the Boko Haram, pledged support for the Caliphate proclaimed by the Islamic State of Iraq and Greater Syria (ISIS) leader, Abu Bakr Al Baghdadi in Mosul, Iraq, but fell short of declaring allegiance to ISIS. Subsequently, Abubakar Shekau declared a caliphate in Gworza, Borno state in September 2014, which the group could not sustain.

Boko Haram terrorism has led to the mass displacement of people in the affected areas. In November 2014, the Office of the United Nations High Commissioner for Refugees (UNHCR) declared that over 100,000 Nigerians have fled to neighbouring Niger since 2013 to escape attacks by Boko Haram, while about 53,000 and 2,700 Nigerians have fled to Cameroon and Chad, respectively.

\section{“...In November 2014, the Office of the United Nations High \\ Commissioner for Refugees (UNHCR) declared that over 100,000 Nigerians have fled to neighbouring Niger since 2013 to escape attacks by Boko Haram."}

In addition, over 650,000 persons have been internally displaced within Nigeria due to attacks by Boko Haram.

The Nigerian government introduced the National Counter-terrorism Strategy (NACTEST) in April 2014 to strengthen Nigeria's official response against terrorism, which seeks to address the root causes of insurgency and terrorism such as poverty, inequality, and unemployment.

A key program introduced under this initiative was the 'Presidential Initiative for the North-East,' which focuses on improving the socio-economic infrastructure and overall economic development of the region.

Other programs adopted by the government include the Safe Schools Initiative introduced in May 2014 to encourage children to attend schools in northern Nigeria amid the threat of terror, and the Victims Support Fund established in June 2014 in partnership with the private sector to empower and rehabilitate victims of terror in the country.

The Nigerian government also engaged in an unsuccessful attempt at a ceasefire with Boko Haram in October 2014, which was brokered in N'Djamena, the capital of Chad. However, the scourge of terrorism perpetrated by the Boko Haram has persisted, despite such official interventions. 


\section{Communal Conflicts}

Communal conflicts over scarce resources, manifesting as inter-ethnic violence, herdsmenfarmer conflicts, and indigene-settler hostilities, also ravaged Nigeria's north-central region, otherwise known as the middle belt in 2014 . Such conflicts are rife in the states of Benue and Nassarawa in the mid-belt region, Plateau in central Nigeria, and Taraba in the north-east. In March 2014, Fulani herdsmen attacked several Tiv villages in the Benue and Nassarawa states, leading to the deployment of specialised mobile police squads as well as the military for internal security operations. In Nigeria, the Fulani, traditional nomads living in several West African countries, constitute the indigenous population that lives in the north-east and north-west of Nigeria, as well as parts of the mid-belt region of Nigeria. The quest for pasture to tend their livestock often brings them in conflict with local Tiv farmers that inhabit the Benue and Nassarawa states.

Similarly, in the Taraba state in northeast Nigeria, which is predominantly occupied by inhabitants from the Jukun ethnic group, armed violence between Fulani herdsmen and Jukun militia led to deaths and the displacement of people in Wukari and surrounding the towns and villages between April and June 2014. It is estimated that at least 300 lives were lost due to communal conflicts in the north-central states of Benue, Nassarawa, Kaduna, Plateau, and Taraba states in 2014.

\section{Renewed Threats in the Niger Delta}

Despite the Niger Delta Amnesty Program of 2009 which rehabilitated and reintegrated into society more than 30,000 militants of the Niger Delta region in southern Nigeria, a segment of former militants have repeatedly threatened to go back to arms if the government does not adhere to the agreement made with the militants to provide jobs and benefits in return for their disarmament. Some former militants have protested the delayed payment of their allowances and their exclusion from the benefits schemes. They have also threatened to blow up oil installations in the region in November 2014, following the purported attempt to impeach President Goodluck Jonathan, the first southern head of state in Nigeria.

The leader of former Niger Delta Peoples Volunteer Force (NDPVF), Asari Dokubo,
"Communal conflicts

over scarce resources,

manifesting as inter-

ethnic violence,

herdsmen-farmer

conflicts, and indigene-

settler hostilities, also

ravaged Nigeria's north

-central region,

otherwise known as the

middle belt in 2014."

continues to speak against the alleged use of Boko Haram violence by northern political elites to frustrate and intimidate the administration of President Jonathan. Dokubo has further threatened a renewal of violence in the region if President Goodluck Jonathan is not re-elected for a second term in the February 2015 elections. It is however, striking that some former combatants under the auspices of the Movement for the Emancipation of Niger Delta (MEND) have pledged support for General Muhammadu Buhari, the main opposition contender. This suggests divisions among the former militants another dangerous trend that could escalate and see greater inter-group violence in the Niger Delta.

Kidnappings by Niger Delta militants also continued in the region, with some hostages released on payment of ransom. These include, (1) the kidnapping of three Dutch nationals and two Nigerians in May 2014; (2) the kidnapping of media personnel (for example, Emma Amaize South-South Regional Editor of the Vanguard newspaper, Shola O'Neil - South-South Editor of the Nation newspaper, as well as Emma Arubi a reporter with Daily Independent) from the creeks of Delta State in mid-November 2014; and (3) the kidnapping of two Pakistani and one Indian construction worker in Emakalakala town, Bayelsa state in late November 2014. 


\section{Looking Ahead}

The audacious attacks by Boko Haram that continued into late 2014 as well as the January 2015 attack on the headquarters of the Multinational Joint Task Force (MJTF), a joint military initiative between Nigeria, Niger, Cameroon, and Chad at Baga, Borno State, suggests that the Boko Haram will continue to wreak havoc in Nigeria in 2015. This is further complicated by the availability of illicit arms in custody of non-state actors and the existence of sleeper cells of armed groups in all of the six geo -political zones in the country - north-east, north -west, north-central, south-east, south-west, and south-south. Unless the cross-border movement of terrorists and illegal arms is curtailed, Nigeria will also remain a theatre for transnational terrorism, as well as other trans-national crime such as drug trafficking, illegal oil bunkering, sea piracy, and cybercrime, with their attendant implications to national security as well as regional security in west and in central Africa.

In view of the post-election violence that characterised parts of northern Nigeria in the 2011 presidential election and the targeted killings of Christians mostly from southern Nigeria, the forthcoming general elections scheduled for February 2015 remain pregnant with the probable outbreak of political violence during and after elections. While there have already been several violent incidents related to the upcoming elections, incidences of political assassination or bombings of large gatherings that accompany political campaigns have not been recorded. On 25 January 2015, hundreds of Boko Haram gunmen launched a predawn attack on the strategically important northeastern city of Maiduguri and were locked in a fierce battle with government troops on the outskirts of the city. The attack reportedly left dozens dead. Ground troops, air strikes and local vigilantes managed to stop the jihadists from penetrating the city. In a separate attack, Boko Haram militants launched a simultaneous attack on the north-eastern town of Monguno and were apparently successful in taking control of the town and its military barracks - further indications that the insurgents are gradually gaining ground in 2015. Monguno, with its huge military barracks, has a strategic importance in that it acts as a buffer to keep Boko Haram from advancing towards Maiduguri. Furthermore, if the propensities to violence are not curtailed, there could be deadly escalations in the coming weeks.
"The Boko Haram is already making bold political statements with targeted attacks, including attacks on military establishments. It would not be surprising if the group resorts to attacking those participating in the 2015 elections."

While efforts are being made to ensure that the elections are conducted successfully across the country, the question of the safety of voters and electoral officials, especially in parts of the Adamawa, Borno, and Yobe states, which are the frontline states prone to terrorist attacks by Boko Haram, remains uncertain. The Boko Haram is already making bold political statements with targeted attacks, including attacks on military establishments. It will not be surprising if the group resorts to attacking those participating in the 2015 elections. Yet, any attempts at the postponement of the elections could stir more tensions, as the political opposition and its supporters seem desperate for change.

There is also the probability of post-election violence following the electoral verdict. For instance, it is speculated that if incumbent President Goodluck Jonathan wins the elections, there could be violent reactions in parts of the north-east and north-west, where oppositional presidential candidate General Muhammadu Buhari has his stronghold. On the other hand, there could be a resurgence of armed militancy in the Niger Delta region, if President Jonathan, who is an indigene of the region, loses his reelection bid. Leader of former Niger Delta Peoples Volunteer Force (NDPVF), Asari 
Dokubo, has repeatedly warned against such an outcome, especially the alleged use of the Boko Haram violence by northern elites to frustrate and intimidate the administration of President Goodluck Jonathan.

The elder statesman and former Minister of External Affairs, Bolaji Akinyemi has suggested that a memorandum of understanding be signed between President Goodluck Jonathan, General Buhari, and their respective political parties. This move would call on their supporters to align their votes and influence the verdict of the 2015 presidential election.

Communal conflicts related to scarce resources, manifesting itself in the form of inter-ethnic violence, herdsmen-farmers conflicts, and indigene-settler hostilities, mainly in north-central Nigeria or the middle belt, will continue in 2015. Additionally, Nigeria remains vulnerable to multiple other non-traditional and human security challenges, among which are associated with the HIV/ AIDS pandemics and other diseases, desertification due to climate change, and environmental stresses.

C. Nna-Emeka Okereke is a Senior Lecturer at the Department of Political Science and International Relations at Caleb University in Lagos, Nigeria. 
In 2014, Somalia experienced attacks by the Al Qaeda-affiliated Harakat al Shabaab al Mujahideen - also known as Al Shabaab, although the group has been weakened with the killing of its leader Ahmed Abdi Godane during U.S. airstrikes in September 2014. Both the African Union Mission in Somalia (AMISOM) and Somali troops has contained the group, recapturing strongholds held by al-Shabaab. Al-Shabaab continued to carry out countless attacks locally and across Somalia's border, although these cross-border attacks were not the first for al-Shabaab - Djibouti experienced it for the first time this year in May.

\section{Threat of Al-Shabaab}

In 2014, Al-Shabaab carried out attacks mainly targeting lawmakers, UNbacked peacekeeping forces, and Somalia's security apparatus. In May 2014, they attacked the parliament resulting in the death of at least 10 people. The twin bomb attacks on UN convoys in the central Somali town of Baidoa on 3 December 2014 resulted in the death of at least 15 people. On 31 August 2014, the group attacked a national intelligence site in Mogadishu resulting in a gunfight. 12 people including the 7 perpetrators were killed in the incident. On 24 May, two suicide bombers of Somali origin blew themselves up in La Chaumiere restaurant, in Djibouti, in an area frequented by international soldiers, killing 3 and wounding 15 others. Although the attacks took place in Djibouti for the first time, the country has been a target of al-Shabaab, due to the presence of western interests within the country as well as Djibouti's support for the Somali government and its participation in AMISOM's mission. 
Al Shabaab also continued to carry out attacks in Kenya, after the Westgate mall siege in 2013 increasingly targeting non-Muslims. On 22 November 2014, al-Shabaab ambushed a bus traveling to Nairobi and shot dead 28 nonMuslims passengers. The incident took place outside the town of Mandera, near Kenya's border with Somalia and Ethiopia. The attack was in retaliation for raids conducted by the Kenyan authorities on mosques in Mombasa city. The raids had led to the seizure of grenades, ammunition and petrol bombs found in two mosques, Swafaa and Minaa. More than 350 people were also arrested in the raids on a suspicion they were undergoing military training. In another attack on 1 December 2014, alShabaab shot dead 36 quarry workers. The group demanded that the workers recite the Quran, separating the Muslims from the nonMuslims, before killing those who were unable to do so at point blank.

\section{Leadership in Al Shabaab}

In September 2014, Ahmed Abdi Godane, who was the leader of al-Shabaab since 2007 following the capture of its first leader Abdullahi Sudi Arale in Djibouti, was killed in in a US drone strike. Thereafter al-Shabaab named Ahmed Umar, also known as Abu Ubaidah, as its new leader - making it the third time the group underwent a leadership transition.

In the past, al-Shabaab's leadership has always been targeted. As a result, many of them went into exile, and were killed or captured by intelligence-led airstrikes and commando operations. For more than two years, the group's leaders have been involved in disputes over ideology, strategy and tactics.

As internal strife about its links with Al Qaeda continued to plague the group, the group remained divided on issues like attacks on civilians, and also concerning the role of foreign fighters within the group. The killing of Godane has been a strategic blow to the group with a potentially demoralising impact on its members. Despite the fact that the group has reaffirmed its loyalty to al-Zawahiri, the leader of Al Qaeda Central, in the wake of Gadani's death, there is concern that al-Shabaab might align itself with Islamic State of Iraq and Greater Syria (ISIS), with the latter's increasing appeal following the declaration of the Islamic Caliphate.

\section{“On 1 December 2014, al-Shabaab shot dead 36 quarry workers. The group demanded that the workers recite the Quran, separating the Muslims from the non -Muslims, before killing those who were unable to do so at
point blank."}

\section{Peacekeeping Missions}

AMISOM's increasing involvement in the country has contributed to a shift in al-Shabaab's strategy, as it has forced the group to leave major towns and cities under their control and shift away from AMISOM's area of operations. The group is believed to have withdrawn from carrying out large-scale attacks to preserve its forces and the capability to wage long-term fight. The group is at an all-time low in terms of its ability to carry out high-profile attacks which it did in previous years. Nevertheless, the group continues to exploit inter-clan tensions, taking advantage of local grievances, and has also been able to obtain resources and recruits.

On 22 January 2014, Ethiopia joined AMISOM in addition to Burundi, Kenya, Uganda, Sierra Leone and Djibouti. Ethiopia is not new to the conflict, it had fought in support of the the Somali transnational government against the alShabaab offshoot known as the Islamic Courts Union (ICU), while their first incursion was in 1996. In 2014, AMISOM executed two operations - "Operation Eagle" and "Operation Indian Ocean. The operations were successful to the extent of a successful overtaking of some areas and cities controlled by al-Shabaab, especially after the capture of key city, Qoryoley in Lower Shabelle. 
This city serves as an access point for al-Shabaab to the port city of Baraawe. The success is mainly due to the increased number of troops in AMISOM, in addition to famines that have plagued the country. The Somali communities also played their part in helping the forces to liberate towns and cities under the control of al-Shabaab.

However, AMISOM's involvement in Somalia is not without challenges. The troops often lack equipments and supplies. There was almost no response to the repeated calls for the provision of aviation assets and armoured personnel carriers to help the AMISOM as well as the Somali forces in terms of logistics like transport. AMISOM is also impaired because of poor road conditions that have made its supply routes vulnerable to attacks and ambushes, in addition to the lack of maritime assets to operate off the coast of Somalia to curb the rise in piracy on the seas.

In August 2014, restrictions by al-Shabaab on the movement of the food and aid into the famine-affected areas controlled by al-Shabaab prevented the government from coming to help the people in need. Given the circumstances, aerial capabilities may have seemed helpful. However such expensive and complex operations remained inaccessible largely due to the government's limited financial resources .

Another key challenge facing AMISOM and Somali forces is the maintenance of control over territories reclaimed from the al-Shabaab. Despite having over 22,000 troops, AMISOM and Somali forces may be overstretched - fighting al -Shabaab and simultaneously holding on to reclaimed territories. Insurgents in the country are not warlords and other militias. The outlook for Somalia is likely to be grim after its withdrawal from Somalia, which is unlikely to be imminent, given the persistence of entrenched violence in the country.

\section{Looking Ahead?}

To be sure, al-Shabaab is handicapped with the killing of Ahmed Abdi Godane. Godane had been leader with strategic vision for the group, inspiring the group to establish links with other extremists to extend its transnational reach. The group now also lacks the support of the Somali community and has in fact isolated sympathisers from the broader Somali Salafi community, owing in part to Godane's biased attitude towards certain Salafi clans.

The increased involvement of AMISOM in the country has helped in decreasing the terrorist threat in the country. Al-Shabaab is on the retreat but nevertheless attempting to regain its strength and re-strategise its mission. Under the circumstances, Somalia is in dire need of both regional and international support to stem the march of one of the deadliest groups that has earned considerable notoriety not only with attacks in the country but beyond.

Syed Huzaifah Bin Othman Alkaff is a Senior Analyst with the International Centre for Political Violence and Terrorism Research (ICPVTR) at the S. Rajaratnam School of International Studies (RSIS), NTU. 


\section{South America}

\section{Colombia}

Steven Jones-Chaljub

In 2014, Colombia experienced a continuation of attacks from the insurgent groups and the country's right-wing armed criminal groups, Bandas Criminales, better known as BACRIMS. The BACRIMS are still in operation in the entire national territory, and their influence is constantly increasing. Despite ongoing peace talks between the Colombian government and the Fuerzas Armadas Revolucionarias de Colombia (FARC) there has been skepticism about the outcome especially by the opposition political parties and the general public. This is due to the parallel agenda and secret concessions from the government, which has been further aggravated by the fact that the peace negotiations are being held without ceasefire.

\section{Key-Players and Attacks}

In 2014, the FARC continued to carry out attacks targeting government forces, civilians and critical infrastructure such as oil and water pipelines, and electrical supply infrastructures. On 18 March 2014, FARC abducted 2 policemen, Germán Méndez Pabón Edílmer Muñoz Ortiz and tortured and eventually killed them. On 15 May 2014, FARC recruited two young boys to carry out a grenade attack on a group of policemen in Tumaco, in the Department of Nariño. However the attack was a failure resulting in the death of the perpetrators. On 19 July 2014, FARC attacked a police station in Arauca, killing a child, and injuring 2 policemen and 1 civilian. On 23 July 2014, FARC forced the drivers of 23 tanker trucks to open the trucks' valves, polluting rivers with over 5.6 gallons of oil, and affecting directly 106 families. On 27 July 2014, FARC's $53^{\text {rd }}$ Front sabotaged the water pipes of Ariai, in the Department of Meta, cutting water supplies to more than 16,000 people. In 29 July 2014, FARC attacked an electric tower in Buenaventura, leaving almost 
half a million people without electricity. On 4 November 2014, FARC murdered 2 leaders of the Nasa indigenous group in Toribío in the Departmento of Cauca.

In addition, the Ejército de Liberación Nacional (ELN) continued to carry out sabotage attacks and attacks on police stations. On 20 September 2014, the group attacked a police station in Arauca killing one policeman. In July 3 the ELN blew up the "Oleoducto Caño Limon-Coveñas," a major oil pipeline in the country. On 13 October 2014 , the group perpetrated an attack, killing two policemen. In the past, the group had been exerting pressure through violent means on the government with the objective of forcing a peace negotiation. In addition, Fuerzas Irregulares de Colombia (FIAC), the youngest of the Colombian insurgent groups, has also been threatening politicians and the population at large, so as to consolidate their presence and control in the region of Los Llanos Orientales.

The Las Bandas Criminales, better known as the BACRIMs, have also been active in 2014. The BACRIMs are the splinters of former right-wing paramilitary group Autodefensas Unidad de Colombia (AUC), which was formally demobilised between the years 2003 to 2006 .

The groups which make up the BACRIMs are the following: EI Clan Usuga (controls Los Urabeños), Rastrojos, Machos, Paisas, and dissidents of El Ejército Revolucionario Popular Anticomunista de Colombia (ERPAC), which are further divided into Libertadores de Vichada and Bloque Meta. Among the groups which make up the BACRIMs, los Urabeños, Usuga and Rastrojos are the ones with major weapon and training capabilities and greatest presence in the Colombian territory. These groups do not have a particular political orientation, but are motivated by the revenues produced by the dark economies (e.g. mining, illegal drugs, kidnapping, and ransom, among others). For this reason, these groups have been carrying out joint attacks together with other groups like FARC that have political agendas. For instance in 16 September 2014, los Urabeños and members of FARC carried out a joint attack on a convoy of the police in the Cordobá department, killing seven members of the police force.

\section{"...the threat of FARC remains salient in the national security landscape and in the minds of the general public."}

\section{FARC}

Among the armed groups operating in Colombia, FARC is certainly the oldest and has proven to be strongest in terms of manpower, weapons and hardware. In addition, the group is also the most active, and most resilient. In the past, the group had enough capacity to use the tactic of 'war of positions' against the state. Successful military operations by the Colombian government had forced FARC to revert to its earlier tactic of using guerrilla warfare.

Although FARC has stated that their attacks were not meant to be targeted at the civilian population, the group is considered a terrorist organisation by a number of countries including the U.S. and EU countries. As the struggle against FARC has lasted over 50 years, the threat of FARC remains salient in the national security landscape and in the minds of the general public.

\section{Government Response and Peace Process}

The government has used various hard and soft approaches to putting an end to the conflict with FARC. The government has been using a mix of hard kinetic operations against the group and soft approaches, including the use of humanitarian packages and incentives to encourage demobilisation and defection.

Under the current President Santos' first administration from 2010 to 2014, the government initiated informal discussions with the FARC which subsequently led to the start of direct exploratory talks with the rebels' representatives in the Cuban capital, Havana, in February 2012. 
There have been number of attempts by the Colombian government to achieve a peace deal with FARC including in 1984 by Former President Betancur, in 1990 by Former President Gaviria, and in 1998 by Former President Pastrana.

All of these have however, failed. Under the current President Santos' first administration from 2010 to 2014, the government initiated informal discussions with the FARC which subsequently led to the start of direct exploratory talks with the rebels' representatives in the Cuban capital, Havana, in February 2012.

One of the challenges in the peace process between the government and FARC is that the talks are being held without a bilateral cease of hostilities. In 2014, a series of events derailed the peace process repeatedly.

For instance, the kidnapping of General Ruben Dario Alzate on 16 November 2014 by FARC in the Department of Chocó forced President Santos to halt the peace talks and ordered his negotiation team to leave the Cuban capital Havana. The case was significant as General Alzata was the first Colombian general to be abducted in 50 years of civil conflict. On 30 November 2014, General Alzate was released by $\mathrm{FARC}$, in an effort to resume the peace talks.

Although the peace talks resumed on 10 December 2014, there is widespread skepticism about the outcome underpinned by the FARC's continuing attacks, which has sparked speculations that the group is using the talks as a platform for propaganda, as the rebels continued to rearm and carry out attacks.

The government has also initiated steps for security sector reforms, including providing more resources and specifying the duties of the police unit. Under these provisions, the police, as a civilian entity, would take charge of internal security including anti-insurgency duties.

However, there are doubts on the capacity of the police to discharge these responsibilities, which traditionally have been done by the military forces, in the immediate term within such a short time frame.

\section{"One of the challenges in the peace process between the government and FARC is that the talks are being held without a bilateral cease of hostilities..."}

The challenge for Santos Administration is to find a proper formula for peace due to ambiguous policies and measures.

For example, in November 2014, Santos' Administration, through Colombia's Chief Prosecutor (Fiscal) Eduardo Montealegra proposed to designate narco-trafficking as a political crime and a crime against humanity. The government argued that FARC has been using illegal drugs as a source of financing its fight against the state, and that since insurrection is a political crime, so should be the means used.

On 30 April 2014, Montealegre suggested that social work, as part of a hearts and minds approach and "zero days in jail", could serve an alternative punishment for members of FARC's top members.

However, on 3 October 2014, Montealegre suggested that maximum punishment for FARC's top members could be demeaning. These rather ambivalent approaches which also ignore the concerns of the victims of violence have put the entire peace process at the risk of failure.

\section{Looking Ahead}

In 2014, violence by BACRIMs and continuing attacks by FARC underscored the serious and complex security threats faced by the country. Meanwhile, obstacles to the peace process remain. 
There is a need for the Colombian government to strengthen its counterterrorism responses to deal with the deteriorating situation caused by these entities. It is also incumbent upon the international community to assist Colombia in terms of capacity building and development projects that will undermine the appeal of the armed groups throughout the country.

Steven-Jones Chaljub is the Defense and Security Advisor at the Escuela Superior de Guerra (ESDEGUE). 
The S. Rajaratnam School of International Studies (RSIS) is a professional graduate school of international affairs at the Nanyang Technological University (NTU), Singapore. RSIS' mission is to develop a community of scholars and policy analysts at the forefront of security studies and international affairs. Its core functions are research, graduate education and networking. It produces cutting-edge research on Asia Pacific Security, Multilateralism and Regionalism, Conflict Studies, Non-Traditional Security, International Political Economy, and Country and Region Studies. RSIS' activities are aimed at assisting policymakers to develop comprehensive approaches to strategic thinking on issues related to security and stability in the Asia Pacific. For more information about RSIS, please visit www.rsis.edu.sg.

\section{3}

The International Centre for Political Violence and Terrorism Research (ICPVTR) is a specialist research centre within the S. Rajaratnam School of International Studies (RSIS) at Nanyang Technological University, Singapore.

ICPVTR conducts research and analysis, training and outreach programmes aimed at reducing the threat of politically motivated violence and mitigating its effects on the international system. The Centre seeks to integrate academic theory with field research, which is essential for a complete and comprehensive understanding of threats from politicallymotivated groups. The Centre is staffed by academic specialists, counter-terrorism analysts and other research staff. The Centre is culturally and linguistically diverse, comprising of functional and regional analysts from Asia, the Middle East, Africa, Europe and North America as well as Islamic religious scholars. Please visit www.rsis.edu.sg/research/icpvtrl for more information.

\section{STAFF PUBLICATIONS}

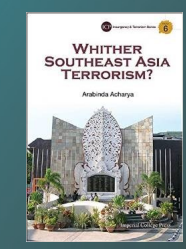

Whither Southeast Asia Terrorism

Arabinda Acharya (Imperial

College Press, 2015)



The Terrorist Threat from Thailand: Jihad or Quest for Justice?

Rohan Gunaratna and Arabinda Acharya

(Potomac Books, 2013)

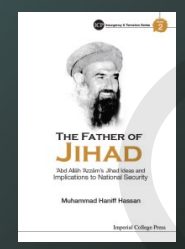

The Father of Jihad Muhammad Haniff Hassan (Imperial College Press, 2014)

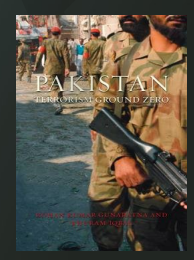

Pakistan: Terrorism Ground Zero

Rohan Gunaratna and Khurram lqbal (Reaktion Books, 2011)

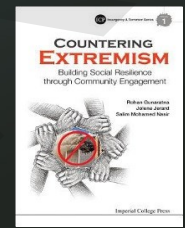

Countering Extremism Rohan Gunaratna, Salim Mohamed Nasir and Jolene Jerard (Imperial College Press, 2013)

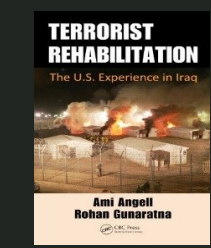

Terrorist Rehabilitation: The US Experience in Iraq

Ami Angell and

Rohan Gunaratna (CRC Press, 2011)

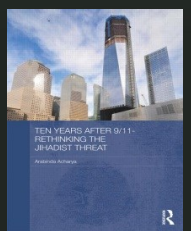

Ten Years After 9/11: Rethinking the Jihadist Threat Arabinda Acharya (Routledge, 2013)

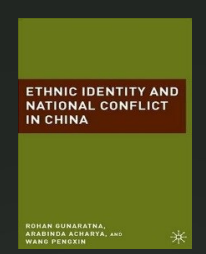

Ethnic Identity and National Conflict in China

Rohan Gunaratna, Arabinda Acharya and Wang Pengxin (Palgrave Macmillan, 2010)

\section{ICPVTR'S GLOBAL PATHFINDER}

Global Pathfinder is a one-stop repository for information on current and emerging terrorist threats from the major terrorism affected regions of the world. It is an integrated database containing comprehensive profiles of terrorist groups, terrorist personalities, terrorist and counter-terrorist incidents as well as terrorist training camps. This includes profiles from emerging hubs of global terrorism affecting the security of the world, as well as the deadliest threat groups in Asia, Africa, the Middle East and the Caucasus. The database also contains analyses of significant terrorist attacks in the form of terrorist attack profiles. For further inquiries regarding subscription and access to Global Pathfinder, please contact Elena Ho Wei Ling at isewlho@ntu.edu.sg. 